\title{
Catolicismo(s) ontem, hoje e sempre...? \\ Interfaces com o tempo, sociedade e cultura.
}

\section{O episcopado restaurador de dom Justino José de Sant'Ana} (1924-1958)

The episcopate restorer of Justino José de Sant'Ana (1924-1958)

Rosiléa Archanjo de Almeida ${ }^{1}$ rosileaarchanjo@yahoo.com.br

Resumo: O presente artigo intitulado "O episcopado restaurador de dom Justino José de Sant'Ana (1924-1958)" exibe um apanhado histórico com foco na influência exercida pela Igreja Católica na sociedade de Juiz de Fora-MG, sob atuação do primeiro bispo juiz-forano dom Justino José de Sant'Ana. Delimitamos os anos de 1924 a 1958 como período de análise para este estudo, por se tratar da ocasião em que dom Justino José de Sant'Ana exerceu a função de primeiro bispo da cidade, tendo como principal característica a ação restauradora sobre a igreja católica local, caracterizada por uma presença expressiva junto a sociedade juizforana.

Palavras-chave: Ação Restauradora; Justino José de Santana; catolicismo; sociedade; Juiz de Fora

Abstract: The present article entitled "The restorative episcopate of Justino José de Sant'Ana (1924-1958)" presents a historical overview focusing on the influence exerted by the Catholic Church in the society of Juiz de Fora-MG, under the performance of the first Judge- forano gift Justino José de Sant'Ana. We delimited the years from 1924 to 1958 as a period of analysis for this study, because it was the occasion in which Justino José de Sant'Ana served as the first bishop of the city, having as main characteristic the restorative action on the local Catholic church, characterized by an expressive presence in the Judiciary society.

Key-Words: Restorative Action; Justino José de Santana; Catholicism; society; Juiz de Fora

\footnotetext{
${ }^{1}$ Jornalista, graduanda em Ciência da Religião pela Universidade Federal de Juiz de Fora (UFJF).
} 


\section{Introdução}

O artigo "O episcopado restaurador de dom Justino José de Sant'Ana (1924-1958)" propõe analisar a influência da Igreja Católica na sociedade de Juiz de Fora entre os anos de 1924 e 1958, período em que dom Justino José de Sant'Ana atuou como primeiro bispo da diocese juiz-forana. Tal análise se torna de fundamental importância no que tange os estudos em torno do tema "Ação Restauradora Católica", vivenciada em todo país e com foco neste texto no primeiro bispado de Juiz de Fora.

O objetivo deste trabalho consiste em demonstrar a influência do catolicismo na sociedade de Juiz de Fora, a partir dos ideais restauradores do bispado de dom Justino José de Sant'Ana (1924-1958), frente às ideias liberais e cosmopolitas da cidade.

A escolha de análise do bispado em questão, se deve a importância de dom Justino para Juiz de Fora, e para as cidades vizinhas que compunham inicialmente a nova diocese, formada por nove foranias ${ }^{2}$ e mais de quarenta paróquias, se estendendo do sul de Minas Gerais à divisa com o norte do estado do Rio de Janeiro (OLIVEIRA, 1978, p.19-20). Destacamos também os desafios que o primeiro bispo do município enfrentou na cidade vanguardista.

Procuramos abordar exclusivamente uma ocasião significativa para a história do catolicismo local e de sua relação com a história do município, a partir do legado restaurador católico durante o primeiro bispado, onde se pode comprovar a intensa participação religiosa na vida cotidiana da cidade, marcada pelo crescimento industrial e cultural defendidos pelo ideal progressista, oposto ao tradicionalismo católico demandado pelos bispos restauradores.

No primeiro capítulo apresentamos os ideais restauradores da Igreja Católica que carregam alguns aspectos da Reforma ocorrida no século anterior, e que serão base do episcopado de dom Justino. Na sequência, resumidamente, contamos a história da formação da Diocese de Juiz de Fora, que após desmembrar-se da Arquidiocese de Mariana, passa a ser governada por seu primeiro bispo diocesano. No último capítulo apresentamos o episcopado de dom Justino, alicerçado sob os ideais restauradores, junto à sociedade local.

Tomamos o catolicismo como núcleo deste estudo, por ser uma das principais religiões presente na composição histórica do município. Denominação religiosa que a partir

\footnotetext{
${ }^{2}$ Divisão geográfica da administração de uma diocese ou arquidiocese, onde se encontraram as Paróquias, unidades menores que abrigam as comunidades (capelas).
} 
da devoção de seus fiéis nomeou o antigo arraial de Santo Antônio do Parahybuna ${ }^{3}$ que originou Juiz de Fora, além de tal religião ser atuante em diversas questões afora das religiosas, da cidade cosmopolita alcunhada de "Manchester Mineira".

\title{
2 Os Ideais Restauradores Da Igreja Católica
}

Tomamos como um dos referenciais teóricos deste trabalho a dimensão social da Igreja vista de modo holístico, ou seja, como uma totalidade (SMART, 1981). Essa abordagem indica que a religião ultrapassa sua validade de sistema de crenças, sendo organização ou parte de organizações com um significado comum e social,

\begin{abstract}
determinada pelos ideais e práticas religiosas e éticas que abriga. [...] é o modo que a religião em questão é institucionalizada, onde através de suas instituições e ensinamento, afeta a comunidade em que encontra. [...] indica a maneira como os homens vivem e são, de fato, moldados por estas reivindicações e a forma pela qual as instituições religiosas operam (SMART, 1981, p. 7).
\end{abstract}

A relação Igreja versus sociedade também pode ser observada nas análises dos sociólogos Émile Durkheim e Max Weber, que embora encarem a religião como "desvio", reconhecem seu potencial

[...] enquanto força social, mas se o primeiro tendeu à descrição das partes que compõem a religião - os mitos e os ritos - e os tomou para pensar, "lá na ponta", a ordenação da sociedade, o segundo direcionou sua pesquisa para a compreensão da religião como aquilo que produz ética e conforma os comportamentos (RODRIGUES, 2014, p. 190).

Além disso verificamos que "para Durkheim, religião é coisa social, enquanto para Weber - talvez, mais do que para Marx -, a religião espelha as determinações históricas de seu contexto social e cultural [...] (RODRIGUES, 2014, p. 194).

\footnotetext{
Constatamos, em primeiro lugar, que o grupo é unido através da repetição recitada dos mitos da tribo. Esta mensagem expressa e proclama nova experienciado desconhecido ou do sagrado. [...] consegue unir aqueles que abre seus ouvidos para ouvir e seus corações para receber a nova verdade (WACH, 1990, p. 54).
}

A presença da religião junto à sociedade pode ser observada em total consonância com o ideal restaurador iniciado em meados do século XIX. De certo modo, a doutrina católica

\footnotetext{
${ }^{3}$ Escrito anteriormente: Santo Antônio do Parahybuna. Cf. Enciclopédia dos Municípios Brasileiros. Vol. XXV, Rio de Janeiro, 1959.
} 
servirá "para iniciar os primeiros movimentos em direção a uma organização oficial no interior do grupo unificado" (WACH, 1990, p. 54).

Em 1916, surge no Brasil o modelo da "neocristandade", resultado dos acontecimentos precedentes de desenvolvimento institucional, mudanças sociais e adaptações que revitalizariam a presença da Igreja na sociedade. A partir deste momento, podemos perceber um envolvimento profundo dos líderes católicos na política até o ano de 1945, em defesa da ordem, da hierarquia, da autoridade religiosa, da educação por princípios religiosos da autoridade eclesiástica e atacando o comunismo. A nova militância surge num contexto de reafirmação do poder e direção de Roma.

Os mais importantes programas da Restauração Católica no país estão anunciados na Carta Pastoral de Dom Sebastião Leme: organização da Ação Católica, luta pela defesa, na Constituição, do ensino religioso nas escolas públicas, criação de escolas católicas, em todos os níveis, especialmente a Universidade Católica. A Igreja estava unificada e o Cardeal Leme tinha em suas mãos a assinatura de todos os bispos do Brasil para, numa emergência, falar em nome da totalidade (CASALI, 1995, p. 80).

Anos mais tarde, Ação Restauradora Católica baseada na necessidade de a Igreja exercer maior presença na sociedade brasileira, "em razão de ser a fé católica um dos elementos constitutivos da nacionalidade" (AZZI, 2000, p. 190), passou a vigorar também no bispado de Juiz de Fora.

A chamada restauração promovida por dom Justino José de Sant'Ana em conjunto com outros bispos do Brasil se preocupava dominantemente com

a presença da Igreja na sociedade brasileira. A Reforma Católica, iniciada em meados do século XIX, fora marcada por uma orientação nitidamente defensiva da instituição eclesiástica, frente ao avanço da ideologia liberal e positivista. Em seguida, com o início da República, iniciara-se o período da Reorganização Eclesiástica (AZZI, 2000, p. 18).

Se o movimento Reformador ${ }^{4}$ nos primórdios do segundo reinado, intentava uma reforma clerical e uma nova catequização da sociedade, na década de 1920 a Igreja terá a intenção de criar uma ordem política e social fundamentada nos princípios cristãos.

\footnotetext{
${ }^{4}$ A preocupação da Igreja quanto ao clero se dava e três níveis: "a falta de espirito eclesiástico, o envolvimento na política e, principalmente, a não observância do celibato clerical" (AZZI, 2000, p. 18). Já o povo, era considerado "ignorante religioso", supersticioso e fanático ao culto. A reforma se daria em eliminar progressivamente os elementos considerados profanos no culto religioso, a partir de uma nova catequização, e fazer com que o clero tomasse as rédeas do rito religioso.
} 
A justificativa dos bispos para tirar do povo a tradicional autonomia na área religiosa era a crise por que estavam passando as confrarias e os centros de devoção administrados por pessoas ou entidades leigas. Em substituição aos leigos, a maioria dos centros de devoção foi confiada a institutos religiosos trazidos da Europa com essa finalidade especifica (AZZI, 2000, p. 19).

O Movimento Restaurador, entretanto, manteve três ideais do Movimento Reformador: "maior formação do clero e da formação religiosa do povo; atitude apologética com relação à maçonaria, o protestantismo e o espiritismo; mentalidade conservadora no que diz respeito aos problemas políticos e sociais" (AZZI, 2000 p. 190).

As propostas restauradoras levavam em consideração uma efetiva presença na sociedade brasileira, visando criar um respeito aos valores tradicionais, intentando "uma reinterpretação (consagração) do elemento tradicional" (WACH, 1990, p. 52) para recuperar a chamada tradição, "sua pureza anterior e recobrir as unidades e certezas que são sentidas como tendo sido perdidas" (HALL, 1997, p. 94).

O movimento visava também uma maior aproximação da igreja com o Estado para o predomínio dos valores de ordem e autoridade "o que os bispos desejam é um acordo de colaboração com o Estado, onde o poder religioso e o civil se unam para defender interesses e metas comuns" (AZZI, 2000, p. 191).

As ideias liberais, democráticas e socializantes, características da modernidade política e social dos Estados eram combatidas, sendo consideradas uma ameaça para a Igreja e os valores da sociedade.

\section{A Formação Da Diocese De Juiz De Fora}

Podemos afirmar que a presença da Igreja Católica em Juiz de Fora está mesclada com a narração da própria história da cidade e pode ser evidenciada desde os primórdios do município no documento local mais antigo, que se encontra no arquivo municipal, datado do ano de 1741. Conforme o site do Arquivo Histórico da Arquidiocese de Juiz de Fora (ARQUIDIOCESE, 2018), nesse ano, foi requerida a licença ao Bispo do Rio de Janeiro para a construção da igreja dedicada a Santo Antônio de Pádua, que aproximaria a família e os vizinhos do fazendeiro luso-espanhol Antônio Vidal. "Tambem he certo que a capella qe o suppte quer emergir hé necessaria e util, não só pa elle e sua familia mas tambem pa os vizinhos, e passageiros de q. hé muy frequentado este camo por ser hoje quasi o único por 
onde se comunicão todas as minas" ${ }^{25}$. Esse documento reforça também a importância do culto aos santos na implantação da fé católica na região. "Até mesmo o fato de o nome do requerente ser homônimo ao de Santo Antônio nos sugere uma homenagem ao Santo, prática comum nesta época, o que nos remete a uma certa 'hereditariedade' da fé" (ARQUIDIOCESE, 2011, p. 13).

Tal pertença dos fiéis católicos com a instituição religiosa pode ser observada, por exemplo, nas expressões culturais e narrativas, como ressalta Arnaldo Érico Huff Júnior e Rodrigo Portella (2018). Quanto mais fiéis vivenciam a verdade de sua crença, mais forte a religião se torna (GRESCHAT, 2005).

Tais narrações e expressões culturais vão ser vividas nas instituições, motivando experiências para o cristão. “A razão sem dúvida, é que não apenas a devoção, mas as instituições sociais, políticas e econômicas em geral, no interior das quais as biografias individuais são vividas, que conferem estabilidade ao fluxo de atividades de um cristão e à qualidade de sua experiência" (ASAD, 2011, p, 266).

Ao longo do tempo, a capela de Santo Antônio passou por mudanças, assim como o povoado, que recebia inicialmente o nome de Santo Antônio do Parahybuna e transformou-se em Juiz de Fora.

Com o aumento da população e da fé católica, foi construído um novo prédio, mais amplo, para abrigar a igreja de Santo Antônio. Conforme o Álbum Juiz de Fora em Dois Tempos, produzido pelo Jornal Tribuna de Minas (1996), a terceira capela teve sua autorização de construção em 8 de março de 1844, mas foi inaugurada somente em 1848 .

Apesar de grande, a capela, rapidamente mostrou-se sem capacidade para abrigar os fiéis e foi necessário construir uma igreja maior, atrás do prédio original. [...] A nova igreja iria funcionar como filial [comunidade] da matriz de Simão Pereira. Junto ao templo se instalou o primeiro cemitério da vila, onde os cristãos foram enterrados por quase 20 anos, até que a ameaça de uma epidemia de cólera morbus ${ }^{6}$, por volta de 1855, impôs a necessidade de se arranjar um local mais distante para o enterro dos $\operatorname{mortos}^{7}$. Mesmo assim, continuaram sendo feitos sepultamentos no terreno da igreja até 1864 (ÁLBUM, 1996, p. 32).

\footnotetext{
${ }^{5}$ HILAIRE, Saint. Voyages dans les provinces de Rio de Janeiro et de Minas Geraes. In: ESTEVES, Albino \& LAGE, Oscar Vidal Barbosa. Álbum do Município de Juiz de Fora. Bello Horizonte, Imprensa Official do Estado de Minas, 1915, p. 46.

${ }^{6}$ Doença infecciosa aguda, contagiosa, que pode manifestar-se sob forma epidêmica, caracterizada, em sua apresentação clássica, por diarreia abundante, prostração e cãibras; cólera-morbo, mordexim (AURÉLIO, 2015).

${ }^{7} \mathrm{O}$ terreno para a construção do novo cemitério foi doado por coronel José Ribeiro de Rezende, localizado até os dias de hoje no bairro Poço Rico.
} 
Em 31 de maio de 1850, foi criada a Freguesia ${ }^{8}$ de Santo Antônio do Parahybuna. No mesmo ano, a capela foi elevada à categoria de matriz paroquial com a alcunha de Santo Antônio do Parahybuna.

\begin{abstract}
Assim, a formação juizforana, a partir do momento de sua fundação como vila, deve ser entendida como um espaço de tentativa de afirmação de dois grupos: em primeiro lugar encontramos a presença de pessoas vinculadas à antiga tradição senhorial, aristocrática e católica, que defendiam a permanência dos valores religiosos herdados do catolicismo tradicional; e em segundo lugar, um grupo mais vinculado às necessidades de uma rápida adaptação a um projeto modernizador de cunho secularizante (PEREIRA, 2002, p. 47).
\end{abstract}

A citação acima é a pura descrição do ideal reformador da Igreja Católica no século XIX, reforçado na Ação Restauradora Católica, seguida anos mais tarde pelo bispo dom Justino José de Sant'Ana.

Além da matriz de Santo Antônio, igrejas de grande importância para o município, já haviam sido criadas na década de 1850.

\begin{abstract}
A cidade que já tinha o topônimo de Juiz de Fora desde 1856 recebeu, nos anos imediatamente posteriores, novos templos católicos, como as igrejas de Nossa Senhora da Glória, de São Sebastião, de São Mateus e de Nossa Senhora do Rosário, além da de São Roque, de especial devoção da colônia italiana (FUNALFA, 2014, p.5).
\end{abstract}

Com o passar dos anos o catolicismo se empenhou na fidelização de seus fiéis e na participação da vida cotidiana da cidade, apresentando sua influência também às características do município, frente à concepção de modernidade que tornava Juiz de Fora uma cidade de pioneirismos. "Ser muito de Deus e pouco de padre. Muito de céu e pouco de igreja, muita prece e pouca missa" (apud YAZBECK, L.1999, p.38).

A pesquisadora Mabel Salgado também destaca em sua obra, o desafio da Igreja Católica frente ao antigo modelo seguido pelo clero juiz-forano, a ser reformulado pelos novos ideais católicos restauradores “[...] Os principais 'inimigos' do catolicismo em Juiz de Fora: a falta de catequese, a instrução religiosa, os escândalos do clero, o indiferentismo religioso, a falta de militância dos católicos, acomodados e adormecidos, embalados pelo Padroado" (AHMJF apud. PEREIRA, 2002, p. 68).

Nesse período, Pe. Júlio Maria ${ }^{9}$ acusou a Juiz de Fora de Nínive, e se dirigiu aos operários em um de seus artigos

\footnotetext{
${ }^{8}$ Atualmente pode-se comparar ao status de Paróquia: sede de uma região composta por diversas comunidades (capelas).
} 
Quantos são os operários que nesta cidade procuram a Igreja já não digo para a confissão e comunhão, mas simplesmente para a assistência à missa? De cada centena se pode tirar um? De fato os operários estão afastados da Igreja; nem sequer de espaço em espaço a procuram.

Jesus Cristo é o Deus dos pobres, dos miseráveis, dos proletários. É principalmente para atraí-los a Jesus Cristo que a Igreja não se cansa de lembrar o seu amor pela pobreza, a sua renúncia dos bens do mundo, a fome e a sede que sofreu... .Quantos são os proletários que procuram a Igreja? Pelas ruas veremos muitos; na Igreja nenhum (BEOZZO apud. PEREIRA, 2002, p. 29).

A partir das observações citadas no princípio de análise deste capítulo, remontamos a criação da Arquidiocese de Juiz de Fora, desejo de dom Silvério Gomes Pimenta, nono bispo e primeiro Arcebispo que de Mariana. "Assim, foi sob o báculo deste bispo que a Igreja de Juiz de Fora passou de um catolicismo de tradição lusa, de caráter predominantemente leigo, para um catolicismo romano e clericalizado" (PEREIRA, 2002, p. 77). Demonstrando o interesse com Juiz de Fora o bispo de Mariana, começou a realizar o "[...] processo de criação de uma nova identidade religiosa, a presença do bispo reformador atuou como um socializador no enquadramento do clero no novo projeto, como uma primeira etapa do desenvolvimento de sua ação com relação aos fiéis" (PEREIRA, 2002, p. 78).

Mas quem realmente deu andamento ao projeto de transformar a freguesia de Santo Antônio em Arquidiocese foi dom Helvécio Gomes de Oliveira, sucessor de dom Silvério como bispo de Mariana.

Em 1924 a então freguesia de Santo Antônio foi elevada à Diocese, tendo seu território desmembrado da Arquidiocese de Mariana. "A Bula Pontifícia 'Ad Sacrosancti Apostolatus Officium' do Papa Pio XI oficializou a criação da Diocese de Juiz de Fora - MG em $1^{\text {o }}$ de Fevereiro de 1924, nomeando como seu primeiro Bispo Dom Justino José de Santana" (ARQUIDIOCESE, 2011, p. 14).

Entretanto, apenas em fevereiro do ano seguinte (1925), instalou-se na cidade o primeiro bispado. "A instalação canônica só ocorreu um ano depois, com a chegada do seu primeiro Bispo. Com a criação da Cúria Diocesana, organizada pelo Monsenhor Domício de Paula Nardy, sacerdote pertencente ao clero marianense [...]” (ARQUIDIOCESE, 2018).

Nesse momento de preparação para a chegada do Bispo, monsenhor Domício de Paula Nardy ficou responsável pela organização da criação da Cúria Diocesana. Ele preparou a

\footnotetext{
${ }^{9}$ Júlio César de Morais Carneiro casou-se em 1877 com Ana Clementina Rothier que faleceu ainda jovem, dando à luz a uma menina. Casou-se novamente com Joana Batista de Menezes Carneiro e teve três filhos. Em 1889, ingressou no Seminário Maior de Mariana. Aos 41 anos, passou a assinar Júlio Maria em homenagem a Nossa Senhora. Em 1892, iniciou sacerdócio em Juiz de Fora como capelão da igreja de São Sebastião.
} 
igreja para a recepção do primeiro bispo, dom Justino José de Santana, que promoveu a Restauração Católica em Juiz de Fora.

O catolicismo juiz-forano que no final do século XIX sofreu com a concorrência de outras denominações recém-chegadas à cidade busca no início do século XX reaver seu alcance majoritário, presente desde os primórdios do povoado.

\section{O Episcopado Restaurador Em Juiz De Fora}

Neste item apresentamos a influência da Igreja Católica na sociedade de Juiz de Fora, no primeiro bispado da cidade, pautado nos ideais restauradores do catolicismo brasileiro, que priorizava a aproximação da Igreja com a sociedade, sendo a fé católica componente da nacionalidade. Várias realizações do bispado de dom Justino José de Sant'Ana balizam tal ideal

A aproximação entre Igreja, Estado e âmbito militar, o surgimento de movimentos sociais católicos, a reafirmação do clero, a fundação da imprensa católica na cidade, do Seminário Santo Antônio e o controle moral da sociedade são alguns traços do episcopado que carregaram características da ação restauradora da Igreja Católica.

Dom Justino José de Sant'Ana foi o primeiro bispo da Diocese de Juiz de Fora. Nascido em 12 de dezembro de 1878, em Aramary, município de Alagoinhas, no estado da Bahia. Aos vinte anos de idade entrou para o seminário de Salvador (BA), e em 1912 desenvolveu o apostolado da imprensa em Canavieiras, onde fundou o periódico "A verdade". Foi quando recebeu a comunicação em 24 de julho de 1924, de sua eleição para bispo de Juiz de Fora.

"A tomada de posse da diocese foi realizada no dia $1^{\circ}$ de fevereiro de 1925. A viagem do Rio a Juiz de Fora, foi feita no trem rápido da Central do Brasil, em vagão especial, o que demonstrava o prestigio que a hierarquia católica conquistava junto ao poder público" (AZZI, 2000, p. 297).

Ao chegar em Juiz de Fora foi aclamado na Praça João Penido ${ }^{10}$, revestiu de seus paramentos no prédio da Associação Comercial e seguiu em cortejo para a Catedral Metropolitana ao som da banda militar. Em seguida, no Clube Juiz de Fora, foi servido um banquete ao primeiro bispo da cidade. O escritor Wilson Bastos descreve como eram os cerimoniais católicos da época.

\footnotetext{
${ }^{10}$ Conhecida com Praça da Estação.
} 
Eu tinha grande entusiasmo pelo brilho litúrgico dos cerimoniais da Igreja, e admirava o seu caráter aristocrático. As vezes ficava indignado com a mordomia a serviço dos bispos. [...] Fora do ritual litúrgico, o povo católico também ajuda a complicar a situação, tirando dos pobres cidadãos investidos da autoridade episcopal o direito de ser livre, tais os salamaleques, os excessos até mesmo de comida, muitas vezes aceitos por simples polidez (BASTOS, 1987, p.154).

O episcopado de dom Justino que tinha como tema "O Senhor é a minha fortaleza" apresentava as características do Movimento Restaurador, e de início demonstrou a revalorização do conceito de autoridade eclesiástica, reduzindo a participação dos fiéis a mera obrigação de submissão, como descreveu o impresso católico "O Lampadário", em 19 de agosto de 1954:

\begin{abstract}
A função dos leigos nesta sociedade hierárquica a respeito dos bispos. Como cristão deve amar e respeitar cada autoridade que vem de Deus, presidente, governador, etc, muito mais do que isso, deve amar e respeitar a autoridade na sociedade perfeita que é a Igreja. [...] Mas os católicos devem especialmente obediência e docilidade ao bispo. Quem não está com o bispo, não está com a Igreja [...] o bispo é o chefe desta parte da Igreja que é a diocese: nós somos os súditos: ele dirige, nós seguimos $(\mathrm{O}$ LAMPADÁRIO, 1954, p. 3).
\end{abstract}

Conforme descreve Riolando Azzi (2000) “O sonho de Dom Justino, portanto, era transformar a cidade e a diocese de Juiz de Fora num território tipicamente católico, onde a vida social fosse pautada exclusivamente pelas diretrizes emanadas pela própria autoridade eclesiástica" (2000, p. 207).

Logo na chegada do Bispo à cidade, nota-se a interação entre Igreja e Estado, no pronunciamento do então senador de Minas, Antônio Carlos, ao "ressaltar o papel da religião na formação moral do povo, contribuindo, assim para a manutenção da ordem e da disciplina na vida social" (AZZI, 2000, p. 199). Ainda acreditava que a "função de controle e manutenção da ordem por parte moral católica devia ser reforçada no país, também como instrumento de contenção da onda revolucionária" (AZZI, 2000, p. 200).

Notamos nesses trechos que a aproximação das duas esferas enfrentariam dificuldades na cidade industrial com ideias liberais, aliado ao protestantismo e ao espiritismo, observado em carta pastoral do próprio Bispo. "O número de protestantes, em toda diocese, mais ou menos, avalia-se em três mil, existindo em Juiz de Fora o famoso colégio Granbery, formado outrossim futuros pastores daquela seita; os espiritas já terão passado de dois mil, há ainda lojas maçônicas em várias cidades do bispado" (SANT’ANA, 1925, p. 7). A fala de dom Justino incorporava a mentalidade aristocrática, considerando-se um verdadeiro príncipe da Igreja. 
A atitude da Igreja Católica frente aos ideais progressistas da cidade considerada vanguardista, pode ser observada no olhar de diversas fonte. "Também o surto de modernidade que marcou a evolução de Juiz de Fora já nas últimas décadas da época imperial trouxe preocupações para o prelado de Mariana, desejoso de manter sua diocese sob a influência dos valores religiosos de tradição conservadora" (AZZI, 2000, p. 15).

Percebemos uma ambiguidade de ideias onde confronta-se a Igreja Católica e sua base tradicional, vinculada à monarquia e defensora de um modelo autoritário de sociedade e o avanço industrial e cultural de uma cidade considerada cosmopolita. A igreja católica e seu movimento restaurador, pautado por uma orientação defensiva da instituição eclesiástica se opõe ao avanço da ideologia liberal e positivista, procurando criar uma nova ordem política e social fundamentada nos princípios cristãos. Como inserir o ideal restaurador católico numa cidade permeada pelos conceitos progressistas?

Juiz de Fora, localizada na zona da mata de Minas Gerais se diferenciava totalmente das demais cidades mineiras com estilo barroco ${ }^{11}$ que

[...] floresceu em Minas no século XVIII, durante o ciclo do ouro, surgiu quando já havia sido superado na Europa. A religiosidade que veio de Portugal (cheia de pompa, reafirmava a fé católica contra o crescente protestantismo), o fascínio pelo ouro e o desejo de afirmação e autonomia são a base para explicar o vigor do movimento artístico mineiro que não se restringia apenas às artes, mas se estendia ao estilo de vida do homem barroco, que preocupado com a efemeridade da vida se sente o desejo de aproveitá-la, mas teme pela salvação espiritual, resultando no sentimento contraditório característico desse período (LINS; BRANDÃO, 2012, p. $39)$.

Daí a alcunha de "Manchester Mineira". A denominação dada por Ruy Barbosa é uma comparação com a cidade da Inglaterra, referência nos aspectos industriais e culturais, como explica a pesquisadora Maíra Carvalho Carneiro Silva (2015, p. 37) "Dessa forma, pode-se entender o título dado à cidade de 'Manchester Mineira', o que, ao lado da expansão dos setores urbanos, permitiu a afirmação do estatuto de modernidade".

No lugar de catedrais, fábricas. Sem a opulência do barroco, o estilo neoclássico e eclético de seus prédios e a racionalidade da arquitetura industrial, que opõe chaminés às torres devotas. Sem a marca da cultura colonial mineira, Juiz de Fora distingue-se pelo cosmopolismo - urbana, moderna. [...] Cidade de operários, imigrantes e pioneiros que, no ritmo das engrenagens dos teares, fizeram-na ingressar no progresso da nova civilização que se anunciava nas metrópoles europeias (ÁLBUM, 1996, p. 1).

\footnotetext{
${ }^{11}$ Estilo sacro que marcou a arte, a literatura, a escultura, a música, a pintura, entre outros aspectos artísticos e culturais brasileiros, entre os séculos XVI e XVIII.
} 
De certa forma, Juiz de Fora intimidava os valores e ensinamentos cristãos católicos. O cenário religioso do município no final do século XIX configurava-se ainda com a vinda de outras denominações para a cidade, forçando uma inevitável disputa pelos fiéis.

Os primeiros anos do bispado de dom Justino, foi de fundamental importância para a retomada da autoridade episcopal e da reinserção do tradicionalismo católico junto a sociedade local, que convivia com um clero mantenedor até mesmo de relações fora do celibato, como no caso do antigo vigário da catedral, padre Thiago Mendes Ribeiro ${ }^{12}$. Dessa maneira, era necessária uma reformulação do clero, "a medida que um sistema de práticas culturais elaborado e complicado se desenvolve, a necessidade crescente de especialistas leva [...] à formação de um corpo de funcionários que assume e de fato monopoliza certas atividades culto. Desta maneira, aos poucos vai surgindo o sacerdócio [...]” (WACH, 1990, p. $58)$.

Para tanto, dom Justino criou o Seminário Diocesano Santo Antônio, em frente à Academia de Comércio, em $1^{\circ}$ de março de 1926, que teve a pedra fundamental do novo prédio, agora na Avenida Barão do Rio Branco, n 4516, lançada em 05 de junho de 1928. “A obra do seminário, iniciada em 1926, constituiu um dos grandes empreendimentos da administração episcopal de Dom Justino, não contando mais com a ajuda financeira do governo como na época imperial [...]” (ARQUIDIOCESE, 2000, p. 246). No mesmo local foi lançada a pedra fundamental da Capela do Seminário no ano posterior.

No mesmo ano, dom Justino fundou o jornal impresso "O Lampadário"

Desde meados do século XIX, quando se instaura no país o movimento de reforma católica, os prelados colocaram entre suas metas a promoção da chamada boa imprensa, com a finalidade de fazer oposição direta à imprensa liberal e maçônica, com seus ataques à instituição Católica (AZZI, 2000, p. 281).

Com base em Pereira (2018), salientamos o interesse de Dom Justino em fundar uma imprensa católica para a cidade.

Considerando a imprensa como um importante instrumento de manipulação de interesses e intervenção na vida social, a imprensa juizforana oferece amplas possibilidades para investigação histórica, pois permite perceber a vida cotidiana em

\footnotetext{
${ }^{12}$ Dirigiu a Paróquia de Santo Antônio entre 1859 e 1890. "No plano de sua vida pessoal ele [Pe. Tiago] vivia publicamente em concubinato, rodeado de filhos numa chácara ao lado da Igreja Matriz, o que parece não ter incomodado a sociedade juizforana, já que o povo estava acostumado a conviver com sacerdotes que possuíam famílias. (PEREIRA, 2002, p. 66).
} 
seus múltiplos aspectos, fazendo emergir sujeitos dotados de consciência em determinadas épocas e suas práticas sociais (PEREIRA, 2018, p. 43).

No Livro de Ivanir Yazbeck (2005), podemos observar a influência da Igreja Católica do Bispo, quando vários bairros mudaram de nome, a pedidos de dom Justino, que era uma figura de grande prestígio social e político

Eu me lembro dos bairros Cachoeirinha, Pito-Aceso, Cafarnaum, Meligionário, Botanágua, Serrinha, Tapera, Arado, Martelos. Atendendo ao pedido do bispo D. Justino José de Santana, o prefeito Olavo Costa decretou a mudança dos nomes, para Santa Luzia, São Benedito, Santo Antônio, Dom Bosco, São Bernardo, São Pedro e outros mais (YAZBECK, I., 2005, p.90).

O episcopado de Dom Justino José de Sant'Ana reafirma o predomínio da tradição católica, tornando a relação com a sociedade primordial para os intuitos restauradores da Igreja.

\section{Considerações Finais}

Este artigo foi apresentado no Congresso nacional de Ciência da religião (CONACIR), realizado entre os dias 6 e 8 de novembro de 2018 na Universidade Federal de Juiz de Fora (UFJF) tendo boa aceitação dos integrantes do GT "Catolicismo (s) ontem, hoje e sempre...? Interfaces com o tempo, a sociedade e cultura".

Pretendemos seguir com esta pesquisa no âmbito da pós-graduação, para que resultados mais sólidos sejam explanados para a comunidade acadêmica e para a sociedade em geral.

Esperamos com este trabalho enriquecer as pesquisas em torno do início da Diocese de Juiz de Fora, e servir como base para as pesquisas em torno da atual Arquidiocese local. Salientamos a importância de estudos no campo de Ciência da Religião que possam aprofundar os conhecimentos acerca da relação entre sociedade e religião, principalmente no que tange a cidade de Juiz de Fora que carece de fontes deste tema.

Todas as ações citadas neste artigo traduzem o poderio de dom Justino José de Sant'Ana e sua penetração na sociedade juiz-forana, transmitindo sua meta de ordem e autoridade apregoada pela Ação Restauradora Católica, onde a fé católica seria o suporte formador de uma nacionalidade cristã.

Dom Justino José de Sant'Ana morreu em 09 de julho de 1958 após um colapso cardíaco. Seu corpo encontra-se enterrado em um mausoléu na Catedral Metropolitana de Juiz 
de Fora, deixando sua herança episcopal restauradora, mantenedora de uma mentalidade aristocrática para a manutenção da ordem social em seu bispado e na sociedade juiz-forana.

\section{Referências}

ÁLBUM Juiz de Fora em 2 Tempos. Juiz de Fora, Esdeva Empresa Gráfica, s.d.

ARQUIDIOCESE de Juiz de Fora. Disponível em:

$<$ http://www.arquidiocesejuizdefora.org.br>. Acesso em: 10 de Out. 2018.

ARQUIDOCESE de Juiz de Fora. Juiz de Fora: nossa História é de fé, nossa igreja tem arte. Dos Primórdios ao Jubileu áureo da Arquidiocese. Juiz de Fora, 2011.

ASAD, Talal. A construção da religião como uma categoria antropológica. Cadernos de Campo, São Paulo, n. 19, p. 1-384, 2010. Disponível em:

$<$ http://www.revistas.usp.br/cadernosdecampo/article/viewFile/44990/48602>. Acesso em 09 Out. 2018.

AZZI, Riolando. Sob o Báculo Episcopal: A Igreja católica em Juiz de Fora (1850-1950).

Juiz de Fora, Centro da Memória da Igreja de Juiz de Fora, 2000.

BASTOS, Wilson de L. Badalo do Sino. Juiz de Fora: Ed. Paraibuna, 1987.

CASALI, Alípio. Elite intelectual e restauração da Igreja. Petrópolis, Rio de Janeiro, Ed, Vozes, 1995.

HALL, Stuart. Identidades culturais na pós-modernidade. Rio de Janeiro: DP\&A, 1997.

HUFF JÚNIOR, Arnaldo Érico; PORTELLA, Rodrigo. Ciência da Religião: uma proposta a caminho para consensos mínimos. Numen: Revista de Estudos e Pesquisa da Religião, Juiz de Fora, v. 15, n. 2, p. 433-456. Disponível em:

$<$ http://numen.ufjf.emnuvens.com.br/numen/article/view/1659/1454>. Acesso em: 10 Out. 2018.

LINS, Flávio; BRANDÃO, Cristina. Cariocas do Brejo entrando no ar: o rádio e a televisão na construção da identidade juiz-forana (1940-1960). Juiz de Fora: UFJF, 2012. O LAMPADÁRIO, Ano XXVIII, n 1457, 19 de agosto de 1954, p. 03.

OLIVEIRA, F. Max de. Sinais da Igreja no Juiz de Fora. Juiz de Fora: Esdeva, 1978 Vol II. PEREIRA, Mabel Salgado. Romanização e Reforma Católica Ultramontana da Igreja de Juiz de Fora: projeto e limites (1890-1924). Disponível em:

$<$ http://livros01.livrosgratis.com.br/cp000142.pdf $>$. Acesso em 10 Out. 2018.

RODRIGUES, Elisa. As Ciências Sociais da Religião como Ciências da Interpretação.

Estudos de Religião, São Bernardo do Campo, v. 28, n. 1, 2014, p. 186-203. Disponível em:

$<$ https://www.metodista.br/revistas/revistasims/index.php/ER/article/viewFile/4645/42>.

Acesso em: 10 Out. 2014.

SILVA, Maíra Carvalho Carneiro. Lugar de trabalhador é na área de serviço. Moradia popular em Juiz de Fora (1892-1930). Disponível em:

$<$ http://www.ufjf.br/ppghistoria/files/2009/12/Maira-Carvalho-Carneiro-Silva.pdf $>$. Acesso em: 13 Set. 2015.

WACH, Joaquim. Sociologia da Religião. São Paulo: Paulinas, 1990, p. 11-72.

YAZBECK, Lola. As origens da Universidade de juiz de Fora. Juiz de Fora: Editora UFJF, 1999. 


\title{
Teologia da Libertação: A luta pela sobrevivência do rosto do oprimido em meio à Restauração Conservadora na Igreja Católica após os anos 1980
}

\author{
Theology of Liberation: The fight for the surviving of the face of the oppressed within the \\ Conservative Restauration in the Catholic Church after the 1980 decade
}

\author{
Alfredo César da Veiga ${ }^{13}$ \\ acv@usp.br
}

Resumo: Destaca a persistência da imagem do excluído na imagética católica após os pontificados de João Paulo II e Bento XVI que empreenderam verdadeira cruzada contra uma teologia política que, segundo essa visão, corromperia a fé e a afastaria de sua ortodoxia. Um tipo de iconografia emergiu como resultado de um retorno conservador, mas uma outra, retratando o rosto do pobre e oprimido, resistiu, como uma "estética marginal"

Palavras-Chave: Iconografia, Arte Sacra, Teologia da Libertação, Igreja Católica

Abstract: It focuses on the persistence of the oppressed people image at the catholic imagistic after the John Paul II and Benedict XVI pontificates who undertook a truly crusade against one type of political theology which, according to that vision, would corrupt faith while would putting it away from orthodoxy. One type of iconography emerged resulted from a conservative return, however, another one, at the same time, showing the face of the poor and oppressed, which resisted as a "marginal aesthetics"

Key words: Iconography, Sacred Art, Theology of Liberation, Catholic Church

Dentre os diversos impactos sofridos pela Igreja Católica da América Latina nos anos $1980^{14}$, destacamos ao menos dois, que julgamos os mais significativos. Esse período representou tanto o ápice da Teologia da Libertação e a representação de um imaginário que retratava o pobre como vítima de um sistema excludente, quanto o retorno conservador iniciado com a eleição do papa João Paulo II, que inicia um verdadeiro esvanecimento da imagética centrada no rosto do pobre.

Esse pontificado foi bastante marcado pela controvérsia. João Paulo II foi, sobretudo, um homem que lutou pela liberdade, talvez por ter nascido num país aonde o próprio pensamento de liberdade não passava de um sonho distante. Wojtyla apresentou ao

\footnotetext{
13 Doutor em História Social (Universidade de São Paulo), doutorando em Psicologia Social (Pontifícia Universidade Católica de São Paulo)

14 Por que os anos 1980? A esse respeito, o professor Francisco Cartaxo Rolim, da Universidade Federal Fluminense lembra que em nenhum outro período os jornais combateram tanto a Teologia da Libertação. Segundo ele, foram 232 artigos, sem contar entrevistas. Os autores, em sua maioria, seriam arcebispos e bispos. A atitude assinala, na sua opinião, um retorno ultraconservador que quer a sacralização do social pela ênfase no religioso. Ver: Neoconservadorismo elcesiástico e uma estratégia política. In: REB. N. 49, de junho de 1989, p. $259-281$
} 
mundo a face de uma divindade mais próxima da humanidade e se aproximou das massas populares com tanta afeição que o povo o considerava um verdadeiro santo em vida.

John Cornwell (2005, p. 13), especialista em assuntos relacionados ao Vaticano, atribui ao atentado sofrido em 13 de maio de 1981, a sua inclinação em deixar ao controle divino os rumos da história, de preferência às intervenções humanas. Mais tarde, no ano 2000, revela o então escondido Terceiro Segredo de Fátima. Disse, na ocasião, que o segredo se referia a ele próprio e, com isso, se torna, a um tempo, o homem das profecias divinas e a vítima da maldade do coração humano.

João Paulo II se tornou, em pouco lapso de tempo, o principal acontecimento da Igreja Católica da contemporaneidade e isso, por si só, o credenciou como aquele que conduziria o catolicismo na direção de um fundamentalismo papal que fazia emudecer as vozes de teólogos, bispos e leigos que pensassem contrariamente. Dessa forma, a catolicidade ocidental foi solicitada a aderir àquela que se acreditava ser a única fé que podia se orgulhar de possuir o monopólio da verdade ${ }^{15}$, conforme se afirmou em vasta documentação desse período $^{16}$.

A partir disso é preciso destacar que o espírito antimodernista que havia prevalecido no período anterior ao Concílio Vaticano II é retomado a partir desse papa. As características comuns não deixam dúvida quanto a isso: fortalecimento do poder papal, reafirmação da ortodoxia e, principalmente, adesão a um tipo de espiritualidade divorciada da reflexão sobre problemas concretos do homem. Para viabilizar tudo isso, utilizou-se de um imaginário típico do século XIX, pietista e quietista que desembocou numa compreensão enclausurada e privada do sagrado ${ }^{17}$.

Podia-se entender as razões pelas quais, naquele período, se utilizou de tais ferramentas. O papa Pio IX, iniciador desse que foi um verdadeiro movimento contra a

\footnotetext{
15 Ibid.,p. 14

16 João Paulo II inicia seu pontificado inaugurando um tempo de reafirmação da doutrina e dos costumes católicos. Uma de suas principais providências nesse sentido foi idealizar um catecismo de doutrina que considerou como sendo "uma norma segura para o ensino da fé", e ponto de referência para as diversas regiões do mundo "tanto em matéria de fé como de moral" (Constituição Apostólica Fidei Depositum). No ano 2000, o então cardeal prefeito da Congregação para a Doutrina da Fé, antigo Santo Ofício, Joseph Ratzinger revive, na Declaração Dominus Iesus, a antiga doutrina extra Ecclesiam nulla salus (Fora da Igreja não existe salvação), do Concílio de Latrão, do ano de 1215.

${ }^{17}$ O papa sublinha, durante o encontro da Congregação Geral da Companhia de Jesus, a realidade e os perigos da secularização, afirmando que esse perigo estava dentro das congregações religiosas com suas ideias ousadas e até radicais. Lembrou aos carmelitas a necessidade de voltar à clausura e à ordem franciscana, em 1985, tomou medidas no sentido de frear a ação dos seus integrantes junto às camadas populares na América Latina.
} 
modernidade ${ }^{18}$, precisava construir uma fortaleza contra o avanço de um mundo que considerava seu grande inimigo. Essa reação foi resultado da separação entre ideais que se chocam no século XIX com o fim dos antigos Estados Absolutistas e a conclusão da unificação italiana e alemã, de um lado, e de outro, o esforço da Igreja em retomar seu antigo prestígio, reduzido a uma condição meramente simbólica.

A Igreja da Cúria Romana sempre acalentou o sonho de voltar a um passado em que reinava gloriosa. Por seu lado, no entanto, a sociedade aprendeu que a única lição que se pode aprender do passado é a sua ineficácia em responder aos problemas do presente. Talvez por isso os últimos papados tivessem sido tão atacados quando procuravam oferecer respostas eclesiais a problemas civis, como a proibição do uso de preservativos em quaisquer circunstâncias, até mesmo para conter o avanço da AIDS.

Com João Paulo II, iniciou-se a busca por um lugar de maior destaque no cenário mundial, por isso foi o papa que mais empreendeu viagens ao exterior e quem mais utilizou os meios de comunicação. Era preciso recolocar a Igreja não somente em diálogo com o mundo, mas como a sua única possível reserva de verdade ou tábua de salvação.

A ofensiva conservadora coube ao então cardeal Joseph Ratzinger. Segundo ele, a hierarquia católica tinha a firme intenção de superar a fase pós-conciliar e instaurar um período de Restauração na Igreja. Com esse termo o cardeal se referia à necessidade de "procurar por um novo equilíbrio depois de todos os exageros decorrentes de uma indiscriminada abertura ao mundo" 19 .

Segundo Della $\mathrm{Cava}^{20}$, o programa de restauração deixava poucas dúvidas quanto à ampliação do campo conservador como a grande prioridade da Igreja naquele momento:

[...] a garantia de uma obediência sem desvios e universal ao magistério e às políticas do governo eclesial central; um retorno ao pensamento reto (ortodoxia) que abertamente evitava a insidiosidade do mundo moderno; uma volta à espiritualidade e devoção ascéticas no meio do laicato e do clero; e, finalmente, uma reinterpretação do Concílio Vaticano II $[\ldots]^{21}$

\footnotetext{
${ }^{18}$ Entendida aqui como ideias que eram veiculadas por intelectuais católicos e leigos que reivindicavam uma reforma estrutural na Igreja. A Igreja sempre considerou o termo Moderno como sinônimo de perigosa novidade, uma vez que poderia colocar em risco todo o seu acervo de doutrinas transmitidas desde os primeiros cristãos.

${ }^{19}$ Vittorio MESSORI. The Ratzinger report, p.37. Esse livro é a tradução para a língua inglesa do texto original da entrevista do cardeal ao jornalista Vittorio Messori, em 1984 e publicada no livro Rapporto sulla Fede, de 1985

${ }^{20}$ Professor de História no Queens College, em Nova Iorque. Em 1982, numa conferência sobre a Nova Igreja Católica na América Latina, o professor discorreu sobre certa política especial que o vaticano reservava para o Brasil a partir da década de 1980.

${ }^{21}$ Politica do Vaticano: 1978-1990. In: REB, n. 200, dezembro de 1990, p. 92
} 
Aquilo que nos interessa, a partir desse ponto, é saber qual o impacto que esse retorno trouxe para a reflexão teológica brasileira que punha o pobre como lugar teológico por excelência e saber de que maneira essa posição afetou o imaginário que havia sido criado em torno do pobre e excluído.

No Brasil, essa restauração se fez sentir em várias frentes, a começar com a imposição de silêncio obsequioso ao frei Leonardo Boff por publicar livros que, segundo a Santa Sé, poriam em perigo a ortodoxia católica ${ }^{22}$. De fato, seus escritos caminhavam na direção de abalar as principais colunas de sustentação da instituição ao questionar a validade da hierarquia e até a própria existência da Igreja como fruto de uma vontade divina. A tese boffiana se contrapõe abertamente à doutrina oficial quando afirma que a Igreja nasce não de um querer divino, mas da decisão de homens inspirados em Jesus Cristo ${ }^{23}$.

As posições pouco ortodoxas de Leonardo Boff trouxeram, para a Igreja do Brasil e da América Latina, a convicção, da parte de Roma, de que aqui havia surgido um inimigo que precisava ser combatido e que tomava a forma de um evangelho identificado com determinado socialismo utópico, conforme esclarece a carta enviada ao teólogo em 15 de maio de 1984 e reproduzida no livro "Igreja: Carisma e poder" (p. 275) pelo próprio autor. Nessa correspondência, o Cardeal Ratzinger declara:

A Igreja de Cristo deve ser edificada na pureza da fé; mas esta pureza da fé exige que a Igreja se liberte não somente dos inimigos do passado, mas, sobretudo dos atuais, como, por exemplo, de um certo socialismo utópico que não pode ser identificado com o Evangelho

Nos anos seguintes, também bispos receberam cartas de advertência, dentre eles, Pedro Casaldáliga ${ }^{24}$, Aloísio Lorscheider, José Maria Pires, Marcelo Cavalheira, Waldir Calheiros e Adriano Hypolito. As razões que motivaram o envio de cartas oficiais foram algumas posições tomadas por esses bispos progressistas, como o fechamento de grandes

\footnotetext{
${ }^{22}$ O Teólogo alemão, Hans Küng, também punido pelo Vaticano alguns anos antes, vê, nesse ato de Roma, "mais um sinal da política de poder restauradora do papa Wojtyla e do cardeal Ratzinger". Cf. A voz da resistência. In: Tempo e Presença, n. 198, Maio/Junho de 1985, p.10

${ }^{23}$ Boff explica essa convicção dizendo que "no início os Doze e os discípulos esperavam ainda pela irrupção próxima do Reino de Deus com a vinda gloriosa e definitiva do Filho do Homem (...). Contudo o endurecimento do povo, o martírio de Tiago, a prisão e fuga de Pedro os induziram a não mais esperar como iminente a irrupção do Reino e a se dirigir aos pagãos. Ao irem em missão (...) assumiram os elementos introduzidos pelo Jesus histórico (a mensagem, os Doze, o batismo, a eucaristia, etc.) e fundaram a Igreja concreta". In: Igreja: Carisma e Poder, p. 240

${ }^{24}$ Casaldáliga era constantemente questionado por Roma por se recusar fazer a visita Ad Limina, obrigatória aos bispos a cada cinco anos. Depois de 17 anos de episcopado resolve fazer a sua primeira visita. Em suas crônicas, lembra a impressão que ficou daqueles dias: "Como aquele Vaticano tem muito de jaula, quiçá dourada. Diante da estátua de São Pedro, em bronze, recordei - como não? - os versos de Alberti, as ganas de Pedro de ver-se, livremente, pescador...". Cf. Pedro CASALDÁLIGA. Cartas marcadas, p. 33
} 
seminários e a preferência por pequenas comunidades nas periferias para a formação do clero, a celebração de missas ao som de atabaques e agogôs com aclamações típicas da Umbanda e do Candoblé como Saravá e o forte envolvimento social e militância política como parte da formação do clero.

Em entrevista à revista Veja, o padre belga, Renato Stormacq, coordenador de pastoral da diocese de Nova Iguaçu disse que, apesar da carta elogiar o trabalho do bispo Dom Adriano Hypolito, também pede "para que não se confunda a pregação do evangelho com a defesa de propostas que estejam ligadas exclusivamente aos aspectos social, político e econômico",25.

Essas investidas romanas, no entanto, não foram suficientes para dar o golpe final na chamada Igreja Popular. Outras medidas mais duras, então, foram tomadas, como a divisão da arquidiocese de São Paulo em dioceses dirigidas por bispos mais alinhados com o pensamento do papa. Os progressistas, que antes eram os responsáveis pelas regiões episcopais, foram isolados em dioceses com católicos conservadores ${ }^{26}$. Os movimentos conservadores receberam reconhecimento pontifício, sinal de institucionalização de expressões notadamente leigas ${ }^{27}$ e muito alinhadas com Roma.

Vale ainda ressaltar que o discurso político-religioso baseado em teorias marxistas perdeu sua eficácia diante do colapso do socialismo no Leste europeu ${ }^{28}$

A restauração romana provocou o solapamento das Comunidades de Base que somente sobreviviam graças à atuação de bispos que lhes davam apoio. Até mesmo na CNBB, o isolamento dos prelados progressistas foi gradual e irreversível, causando fragmentação e confusão nas estratégias pastorais a serem adotadas (VÁZQUEZ, 1998, p. 111).

\footnotetext{
${ }^{25}$ Outro pito de Roma, p. 108

${ }^{26}$ Dom Angélico Sândalo Bernardino foi transferido para a recém-criada Diocese de Blumenau. Era o principal incentivador das Comunidades de Base nas regiões episcopais por onde passou: Belém, São Miguel Paulista e Brasilândia, na arquidiocese de São Paulo. Desses lugares procediam os subsídios e novenas que mais apresentavam o rosto de uma Igreja Popular.

Para Dom Celso Queiroz, em quem o cardeal Dom Paulo Evaristo Arns apostava para seu sucessor, foi criada uma diocese no interior de São Paulo, na cidade de Catanduva. Dom Fernando Penteado, da região episcopal de Itapecerica da Serra, SP, foi transferido para Jacarezinho, interior do Paraná. Antonio Gaspar, de Santo Amaro, foi para Barretos, SP. O único a permanecer na arquidiocese até a sua morte, em 1999, foi Dom Joel Ivo Catapan, de orientação mais moderada.

${ }^{27} \mathrm{O}$ institucionalização dos movimentos, através do seu reconhecimento oficial, teve a reprovação de algumas conferências episcopais, como a espanhola, que viam o perigo, com isso, de transformar tais movimentos em igrejas paralelas. As comunidades de base não receberam a mesma atenção, apesar de serem, também elas, movimentos eclesiais.

${ }^{28}$ Logo depois desse acontecimento, estive em um encontro promovido pela então Região Episcopal de Itapecerica da Serra com Plínio de Arruda Sampaio. Perguntei-lhe sobre o futuro da Teologia da Libertação depois da queda do muro de Berlim. Ele reconheceu que seria mais difícil, a partir daquele momento, convencer setores da Igreja a respeito dos discursos dessa teologia que caminham no sentido de sonhar com uma sociedade igualitária, uma vez que os teólogos sempre idealizaram governos como o da extinta União Soviética e Cuba. No entanto, acreditava ainda que a Teologia da Libertação sempre teria seu espaço dentro da Igreja.
} 
Aos poucos, párocos e bispos começaram a permitir, dentro dos seus territórios, a penetração de grupos mais conservadores e menos contestadores, como os grupos de oração da Renovação Carismática Católica (RCC). É fato, também, que o sucesso dessa penetração acontece, sobretudo, pela atenção que dá aos problemas individuais e imediatos das pessoas, como dificuldades financeiras e de saúde. Em muitos casos, o encontro de um movimento com característica mais espiritual e outro mais social numa paróquia, criou uma aglutinação de forças, antecedido por fortes tensões, como na paróquia do Senhor do Bonfim, na Bahia, tradicionalmente forte reduto das Cebs e das ideias da Teologia da Libertação, surgiu um caso prático que ilumina essa questão:

\begin{abstract}
Recentemente, há coisa de uns dois anos, apareceu na paróquia, vinda de Salvador, uma pessoa que queria iniciar ali um grupo de oração. Isso lhe foi proibido. Meses depois da primeira investida, a pessoa e outras da paróquia fizeram novamente a proposta. Desta vez um dos religiosos aceitou. Porém, propôs-lhes que isso acontecesse num ritmo que incorporasse as pessoas das Cebs. Assim foi feito. Os grupos de oração incluíam moças e rapazes, mulheres e homens das Cebs. Desse modo, as questões das lutas sociais começaram a aparecer nas orações e várias dinâmicas de solidariedade também, como por exemplo, a participação na Campanha da Ação da Cidadania contra a Fome e pela Vida.

A experiência inclusiva [...] modificou o estilo do grupo de oração. Mas o modelo de oração introduziu uma nova forma de viver a espiritualidade nas Cebs da região [...] (IULIANNELLI, 1997, p.28)
\end{abstract}

Apesar desse exemplo que é, não raras vezes, exceção, a RCC, na verdade, representa a volta de um sagrado cujo legítimo representante é o padre. Essa atitude criou a sensação de que permanecer ao lado do padre é sinal de pertença à Igreja. Desse modo, a experiência ficará restrita a uma conversão do coração, motivada por hinos de louvor e adoração, momentos de cura e libertação. De resto, a solução de problemas sociais, como desemprego, conflitos familiares, drogas e violência, é buscada não com protestos, mas através do simples e quase mágico poder da oração.

Portanto, um novo rosto estava se desenhando, e isso se pode perceber já por ocasião do Sínodo das Américas em Santo Domingo (12/10/1992), proposto pelo próprio papa João Paulo II. Nas conclusões do Sínodo, nem sequer se mencionou as Comunidades Eclesiais de Base (Cebs). Os novos agentes eclesiais não são mais os pequenos e pobres que articulam fé e vida, mas os antigos modelos: a família, a paróquia, as comunidades religiosas, movimentos, sacerdotes e leigos ${ }^{29}$.

\footnotetext{
${ }^{29}$ Para uma análise mais completa desse encontro, ver: Oscar BEOZZO. Sínodo dos bispos: Assembleia especial para a América. REB n. 57 de março de 1997, p. 82-102
} 
O pobre, que mereceu especial atenção da atividade eclesial na América Latina, especialmente depois de Medellín e Puebla, agora, sob uma ótica mais conservadora, se transforma em simples objeto de virtude ascética, deixando, assim, de merecer atenção especial da ação pastoral da Igreja. O modelo assistencialista, tão combatido pelos teólogos da libertação, retorna com toda a força.

Como se isso não fosse suficiente, era preciso responsabilizar a Teologia da Libertação como a causadora dos muitos males na sociedade. Segundo o teólogo Pablo Richard (1985, p. 15),

[...] para eles (os setores conservadores), estes últimos vinte anos representaram uma época de crise da Igreja, onde ela entrou em decomposição, de diminuição de influência. Os setores conservadores avaliam os movimentos de renovação, como por exemplo a Teologia da Libertação, como a causa de todos os males da sociedade moderna. Para eles o movimento ecumênico, os movimentos feministas, são os responsáveis pelo consumismo, pela libertação sexual, pelo materialismo, pela perda dos valores éticos. Eles não valorizam os movimentos renovadores, porque eles não vêm o mundo sob a perspectiva dos oprimidos [...]

O novo cenário eclesiástico acabou por gerar um consenso de imagens. Quando, no Brasil, o discurso era sobre a situação de pobreza de grandes massas relegadas pela sociedade pós-industrial, o retrato do pobre era predominante. Por outro lado, com a mudança de discurso e com acento maior no espiritual e na relação com o divino, outros estilos na arte acompanharão a nova linguagem.

Juntamente com um discurso mais conservador, a arte sacra passa a refletir os sentimentos que parecem se mover entre o desejo de estabelecer uma nova cristandade com seu passado glorioso e a resistência a um mundo secularizado. Em outras palavras, esse movimento se posiciona com relação àqueles que não sabem decidir entre viver num mundo de meias-verdades e o ideal de uma certeza absoluta (ZABALA, 2006, p. 35). O retorno conservador pretende, assim, apontar o caminho para encontrar essa certeza.

É nesse contexto que emerge uma imagética religiosa portadora de forte argumento teológico que não apenas fornece a narração de um fato, mas que convida o contemplador a pensar teologicamente e a aderir ao conjunto de doutrinas como porto seguro em épocas de incertezas, de forma que a pintura sacra se transforma em uma representação de valores e os modelos de leitura conformes a esses valores (ARGAN, 2004, p. 21).

Podemos, portanto, afirmar a existência de tendências marcantes entre a década de 1970 até os dias de hoje na imagética da arte religiosa. No primeiro caso, a arte reflete a realidade do homem, o seu dia a dia com suas preocupações materiais e busca de 
sobrevivência, alicerçada em uma convicção política. No segundo caso, com o silenciamento de um tipo de teologia engajada nas lutas do povo, começou a despontar uma representação que rompe com o mundo natural e se integra em outro plano, mais distante das realidades terrenas e mais concentrada no aspecto místico da religião.

A partir dos pontificados de João Paulo II e Bento XVI, nota-se uma tendência entre artistas, teólogos e religiosos em demonstrar renovado interesse pela riqueza artística e forte mística que o Oriente vem despertando na mentalidade contemporânea e na maneira de compreender e experimentar o sagrado. Tal interesse se revela, sobretudo, depois de constatar que existe um processo no sentido de dispensar a mediação de instituições religiosas, onde, regularmente, o sagrado é entendido e buscado de forma subjetivista e descompromissada, assumindo o papel de catarse, que pretende reduzir a experiência religiosa à mera terapia, sem conexão com alguma conduta ética. Esse comportamento resulta na interpretação da realidade social e histórica que reinterpreta o mundo a partir de sentimentos pessoais, relegando ao esquecimento as conquistas da sociedade industrial e demonstrando clara ignorância com relação aos problemas que criam as grandes utopias da história (TERRIN, 2004, p. 110).

Destaque-se, ainda, o fato de que, mesmo entre artistas sacros contemporâneos, como Cláudio Pastro, que assumem postura crítica em relação aos excessos da sociedade capitalista, se veem inseridos num contexto que reforça a imagem da autoridade depois das crises das instituições, procuram refúgio em um mundo harmonioso, distante de uma inserção na vida civil. No caso da iconografia cristã contemporânea, esse refúgio se faz num mundo medieval, repleto de ícones bizantinos e arquitetura românica, como no caso desse artista sacro (fig. 1). 


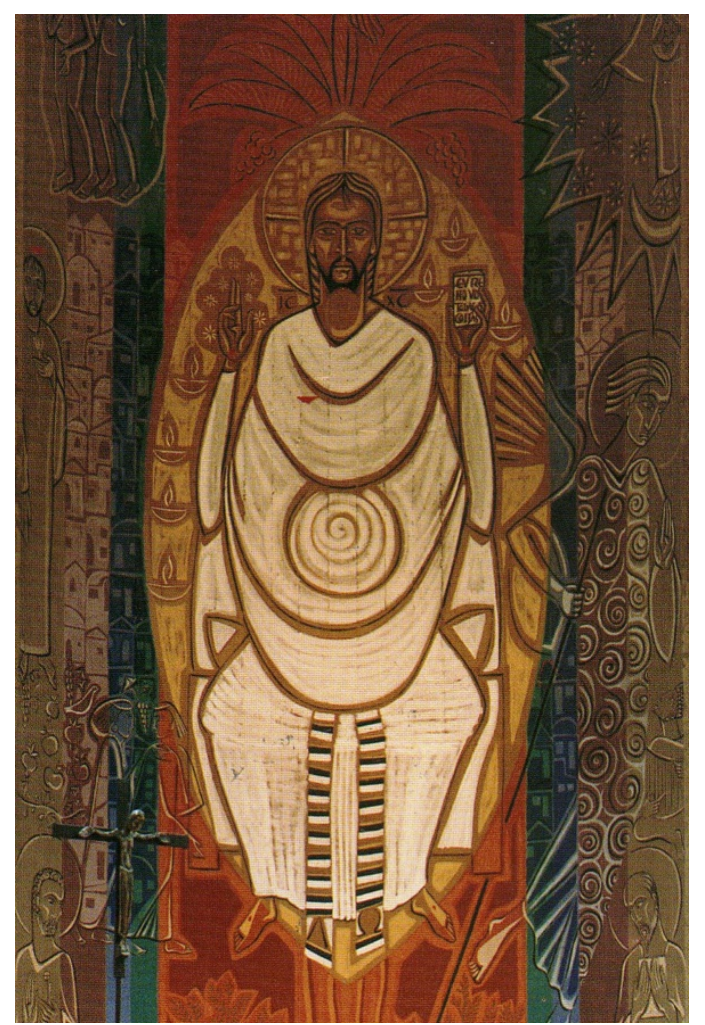

(Fig. 1) Cláudio Pastro: Cristo Pantocrator: Detalhe do interior da igreja abacial do Mosteiro da Virgem, Petrópolis, RJ (1986)

A volta ao passado é um sintoma bastante típico da pós-modernidade que inflaciona e alarga os limites da memória na forma de esforços para a preservação de patrimônios, na proliferação de museus, na revitalização de centros históricos. $\mathrm{O}$ antigo e o nostálgico são explorados com fins comerciais e convertidos em consumo, como destacou o filósofo francês Gilles Lipovetsky (2004, p. 89):

[...] esse retorno revigorado do passado constitui uma das facetas do cosmo do hiperconsumo experiencial: trata-se não mais de apenas ter acesso ao conforto material, mas sim de vender e comprar reminiscências, emoções, que evoquem o passado, lembranças de tempos considerados esplendorosos. Ao valor de uso e ao valor de troca se junta agora o valor emotivo-mnêmico ligado aos sentimentos nostálgicos $[\ldots]$

Os artistas sacros contemporâneos, compreendem o passado, não como produto de consumo nostálgico, mas como um retorno às fontes do Cristianismo, de onde extraem a força da tradição cristã. É também da imagética medieval e de autores desse período que constroem sua estética e fundamentam sua mística, como se pode verificar facilmente através da riqueza de símbolos, da idéia de beleza, da concepção do edifício e da forte atração pelos ícones sagrados. 
Um desses artistas muito requisitado em projetos de igrejas, Cláudio Pastro (1993, p. 88), acredita que, assim como a Igreja foi a guardiã do saber nos tempos difíceis da Idade Média, assim ela pode representar o refúgio para o homem contemporâneo ante a instabilidade e complexidade do nosso mundo. A Igreja é, na sua opinião, $o$ "único lugar onde o homem se torna "um", no sentido de que o reintegra àquela unidade primitiva que perdera no paraíso.

Ao recuperar a simbologia cristã medioeva oriental em seus trabalhos artísticos, querem que se veja neles refletida a grandeza da divindade. A harmonia das cores e dos objetos deve conduzir a uma beleza metafísica que, ao mesmo tempo em que estabelece uma distância física, aproxima e seduz, uma "mescla de prazer e tristeza, de estupefação e humildade, de admiração e nostalgia, um sentimento 'romântico' que goza da bela forma artística, como de uma beleza oscilante entre o Infinito e o Nada" (PASTRO, 1993, p. 83).

Enfim, a tendência dos artistas sacros contemporâneos se concretiza em suas obras que revelam a divindade escondida em estilos distintos, mas que se reúnem quando a finalidade é a de mostrar a força do sagrado retratado na fortaleza do românico, no esplendor colorido e de olhos bem abertos dos ícones bizantinos e ainda na simplicidade e limpeza do espaço monástico, cujo único ornamento deve ser a presença do Invisível, que o preenche e plenifica.

Para quem entra em muitas igrejas, hoje, percebe, imediatamente, a representação do Cristo como o Pantocrator (apud DONADEO, 1997, p. 43) ${ }^{30}$, aquele que tem em suas mãos o poder sobre todas as coisas, sobre a vida e sobre a morte, o poder de realizar milagres e ressuscitar. O Cristo da devoção popular, presença constante na arte cristã dos últimos séculos, tende a desaparecer aos poucos.

Se fosse possível reunir todos esses artistas, encontrando neles algo que os identifica, poderíamos afirmar que na maioria das vezes, essa marca está nos olhos amendoados e constantemente abertos dos ícones que parecem congelar o olhar para algo além deste mundo, a policromia abundante, lembrando a dignidade e a grandeza da divindade, a pedra maciça para recordar a solidez da instituição e finalmente nos espaços limpos para transmitirem a idéia da beleza através da simplicidade.

\footnotetext{
${ }^{30}$ Segundo Capizzi (Apud DONADEO, 1997: 43), "A Patrística, baseando-se em dados revelados pelo Antigo e pelo Novo Testamento e utilizando algumas noções e expressões da filosofia helenística, determinou o conceito de Pantokrator, discernindo nesse epíteto divino quatro elementos conceituais: o onidomínio, a oniconservação, a onicontinência, a onipresença. Deus, em outras palavras, é Pantokrator porque domina sobre todo o criado..., conserva tudo no ser..., abraçando e contendo tudo em si... e, por conseguinte, penetrando e plenificando tudo em si pela sua onipotência... Além disso, a Patrística tem o mérito de ter desenvolvido o sujeito de atribuição do Pantokrator, passando de Deus indistintamente e Deus Pai a uma atribuição consciente e justificada ao Filho como Logos, portanto, ao Filho como Logos encarnado"
} 
Entretanto, concomitante a essa tendência, existe outra que podemos chamar de estética de resistência nas representações religiosas. Nela a Teologia da Libertação continua viva, procurando sempre mostrar que os pobres ainda existem. Ela é fruto da persistência daqueles que não se entregam, mas que continuam acreditando na viabilidade de uma reflexão que parte do contato com as camadas mais sofridas da sociedade.

No Brasil, o artista que mais se identifica com esse tipo de iconografia é Maximino Cerezo Barredo ${ }^{31}$. Dentre seus trabalhos, destacam-se os seus onze Murais da Libertação, criados entre 1977 e 2001 em igrejas de São Félix do Araguaia, no Estado do Mato Grosso e que hoje são bens culturais tombados pelo Patrimônio Histórico.

$\mathrm{O}$ artista assume, em suas obras, uma iconografia recheada de símbolos religiosos e místicos que, longe de significar um mero sentimento religioso, é, antes de tudo, um instrumento de denúncia e protesto. Assume um ethos revolucionário quando denuncia a técnica como promessa de salvação da humanidade e alimenta a esperança utópica de uma sociedade liderada pelos deserdados do poder. No fundo, ainda crê na utopia de um proletariado dando as regras do jogo no desenvolvimento de um mundo tecnológico.

De fato, retratando a religião e os costumes do povo, Cerezo quer aproximar esse povo da sua arte, assim como a própria retratação do sagrado, que lhes fala de seus problemas, das mazelas experimentadas ao longo de anos onde, religião e poder, não poucas vezes, se uniram em prejuízo da população. É nesse sentido que suas obras têm caráter revolucionário.

Contrariando a tendência atual em retratar o Pantocrator como o arquétipo da beleza na arte cristã contemporânea, a Virgem se sobressai, não como uma rainha entronizada, mas como uma mulher do povo, cuja presença esmaga os inimigos e alcança, com braço forte, os abandonados. Aqui, mais do que simplesmente santa, ela é, sobretudo, a mulher: exemplo de luta contra a discriminação e opressão do forte e do poderoso. Seu canto é repetido pelas comunidades em busca de libertação: "Dispersou os orgulhosos, derrubou os poderosos de seus tronos e exaltou os humildes" (Lucas 1, 51), como retratado na figura abaixo (fig. 2):

31 Nascido em Villaviciosa, Astúrias, Espanha, em 1932. É sacerdote da congregação dos missionários claretianos. 


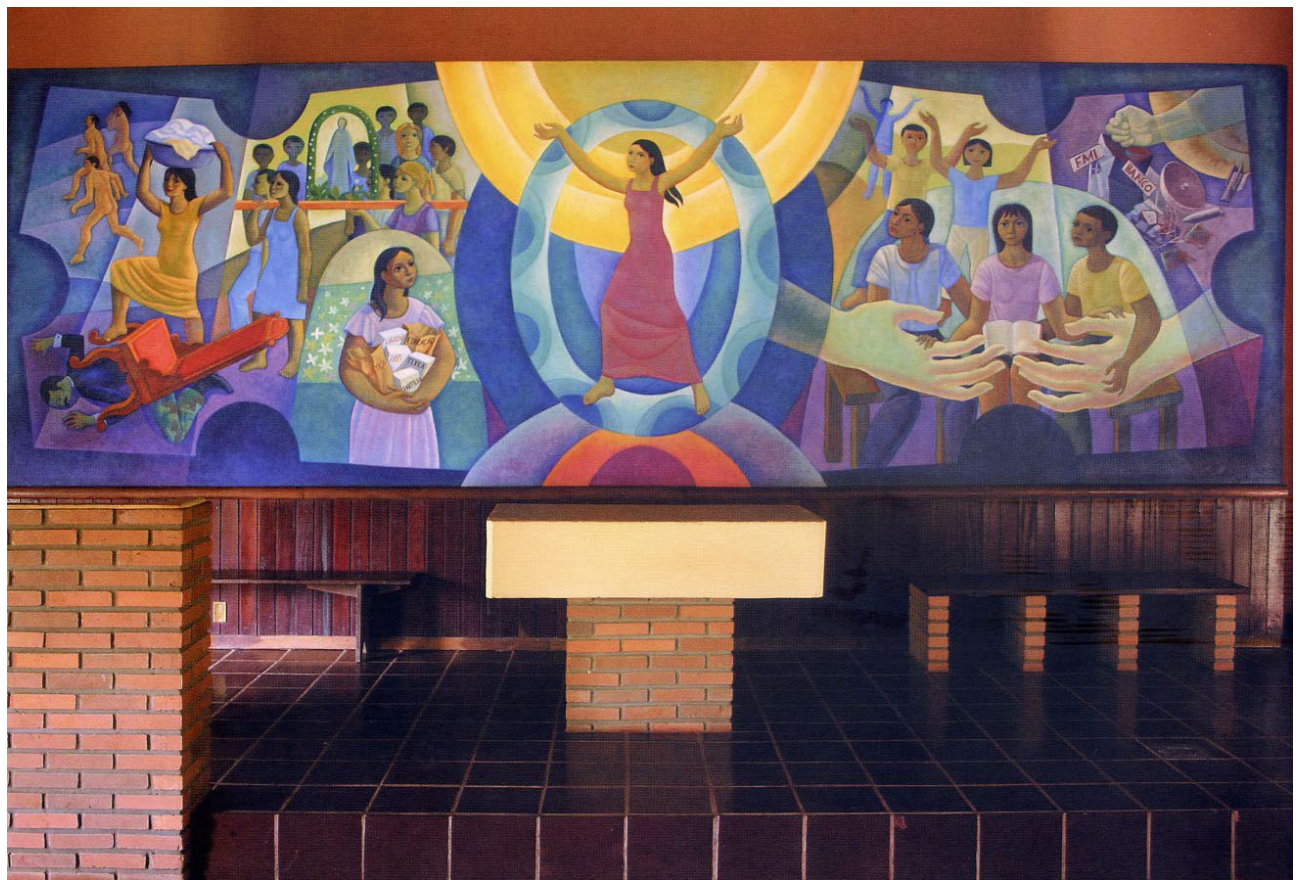

(Fig. 2) Cerezo BARREDO. Magnificat, 1993. Santuário de Luciara, MT. Mural 7 x 2,80 m

Haveria algo em comum entre as duas representações acima? Sim. Ambas recorrem à imagem como fonte de persuasão, e ambas são criadas debaixo de uma inspiração bíblica. Essa recorrência tem o significado simbólico de fornecer um ancoradouro seguro em tempos de intempéries, ao mesmo tempo em que, fazendo uso de representações de um passado bíblico, se busca uma força política para reforçar sua razão de ser no presente de qualquer orientação, seja de esquerda ou de direita, no contexto da religião.

No entanto, o que as diferencia é que, enquanto uma (fig. 1) busca no passado um ancoradouro para a fé e o fortalecimento dos laços tradicionais, a outra (fig. 2) busca, no mesmo passado, inspirações que evocam força moral que possa servir de inspiração na regeneração do rosto vilipendiado do excluído. Ao contrariar regras e até mesmo se aproximar do blasfemo em suas representações, a TL não pretende tirar do divino a sua força, mas, antes, reforçar, no homem, o que há de melhor nele e algo que possa, nele mesmo, evocar esse divino.

A persistência desses rostos está aí para provar que o pobre continua a questionar, a insistir e a gritar. Sua presença incômoda, para uma sociedade cujos valores últimos só podem ser avaliados pelas sua capacidade de consumo, é um claro prenúncio de que profano é esquecer esse rosto, heresia é não fazer dele o protótipo da verdadeira beleza que se esconde debaixo de uma vida vivida em constante angústia e desespero. 


\section{Bibliografia}

ARGAN, Giulio Carlo. Imagem e persuasão. São Paulo: Companhia das Letras, 2004 BOFF, Leonardo. Igreja: Carisma e poder. Petrópolis: Vozes, 1981

CASALDÁlIGA, Pedro. Cartas marcadas. São Paulo: Paulus, 2005

CORNWELL, John. A face oculta do pontificado de João Paulo II. Rio de Janeiro: Imago, 2005

DONADEO, Maria. Ícones de Cristo e dos santos. São Paulo: Paulinas, 1997

IULIANELLI, Jorge Atílio Silva. Pastoral neoconservadora ma non troppo: RCC e Cebs. REB. Petrópolis: Vozes, n. 225, p. 5-38, Março 2005

LIPOVETSKY, Gilles. Os tempos hipermodernos. São Paulo: Barcarolla, 2004

PASTRO, Cláudio. Arte sacra: O espaço sagrado hoje. São Paulo: Loyola, 1993

TERRIN, Aldo. Antropologia e horizontes do sagrado. São Paulo: Paulus, 2004

VÁZQUEZ, Manuel. The Brazilian Popular Church and the crisis of Modernity. Cambridge, UK: Cambridge University Press, 1998

VEJA. Outro pito de Roma. São Paulo, ano 21, n.43, p. 108-109, 26 outubro 1988. Edição 1051

ZABALA, Santiago. Uma religião sem teístas e ateístas. In: RORTY, Richard; VATTIMO, Gianni. O futuro da religião: solidariedade, caridade, ironia. Rio de Janeiro: Relume Dubará, 2006 


\title{
Papa Francisco: um olhar integral sobre a criação e o ressoar da teologia da libertação na atualidade
}

\author{
Pope Francisco: an integral look at the creation and resonance of liberation theology today
}

\author{
Ana Lúcia de Araújo Portes ${ }^{32}$ \\ alaportes77@gmail.com
}

Resumo: "Que tipo de mundo queremos deixar a quem vai suceder-nos, às crianças que estão a crescer?" (LS 160). Esta é a interrogação central da encíclica Laudato Si escrita pelo Papa Francisco sobre o cuidado da casa comum. No decorrer da encíclica ele prossegue, demonstrando que esta interrogativa abrange um sentido bem mais amplo "Esta indagação não toca apenas o meio ambiente de maneira isolada, porque não se pode pôr a questão de forma fragmentária", e isso conduz a interrogar-se sobre o sentido da existência e sobre os valores que estão na base da vida social: "Para que viemos a esta vida? Para que trabalhamos e lutamos? Que necessidade tem de nós esta terra?: "Se não pulsa nelas esta pergunta de fundo, - diz o Pontífice - não creio que as nossas preocupações ecológicas possam surtir efeitos importantes". Desta forma pode-se perceber que há uma preocupação em questionar qual o real sentido da existência de cada indivíduo.

Palavras-chave: Cuidado, Papa Francisco, Laudato Si, Teologia da Libertação

\begin{abstract}
The present study presents itself as an invitation to reflect on the world we will leave for future generations, what care we are taking or should have with creation and with creatures. The basic text used is the encyclical Laudato Si of Pope Francisco on the care of the common house. In the course of the encyclical he demonstrates that reflection on an integral ecology is also a question of the meaning of existence and of the values that underlie social life: "Why do we come to this life? What do we work for and fight for? What need does this land have of us ?: "If you do not press on them this fundamental question," says the Pontiff, "I do not believe that our ecological concerns can have important effects." In this way it can be perceived that there is a concern in questioning the real meaning of the existence of each individual. In addition, the text seeks to parallel the view currently presented by Leonardo Boff on the issue of ecological consciousness, as a new resounding of liberation theology today, a new focus and change of perspective that embraces all and creation in its entirety. Key Words: Care, Pope Francisco, Laudato Si, Theology of Liberation, Integral Ecology.
\end{abstract}

\section{Introdução}

A proposta de estudo aqui colocada tem como mote a pergunta: "Que tipo de mundo queremos deixar a quem vai suceder-nos, às crianças que estão a crescer?” (LS 160). ${ }^{33}$ Esta é

\footnotetext{
${ }^{32}$ Mestra em Ciência da Religião UFJF

${ }^{33} \mathrm{LS}$ ao longo do texto e uma sigla que será utilizada para designar a encíclica Laudato $\mathrm{Si}$, e o numero subsequente refere-se ao parágrafo em que a citação pode ser encontrada.
} 
a interrogação central da encíclica Laudato $\mathrm{Si}^{334}$ escrita pelo Papa Francisco sobre o cuidado da casa comum. No decorrer da encíclica ele prossegue, demonstrando que esta interrogativa abrange um sentido bem mais amplo "Esta indagação não toca apenas o meio ambiente de maneira isolada, porque não se pode pôr a questão de forma fragmentária", e isso conduz a interrogar-se sobre o sentido da existência e sobre os valores que estão na base da vida social: "Para que viemos a esta vida? Para que trabalhamos e lutamos? Que necessidade tem de nós esta terra?: "Se não pulsa nelas esta pergunta de fundo, - diz o Pontífice - não creio que as nossas preocupações ecológicas possam surtir efeitos importantes". Desta forma pode-se perceber que há uma preocupação em questionar qual o real sentido da existência de cada indivíduo.

O nome da Encíclica teve sua inspiração na invocação pronunciada por São Francisco de Assis "Louvado sejas, meu Senhor " que no Cântico das criaturas recorda que a terra, a nossa casa comum, "se pode comparar ora a uma irmã, com quem se partilha a existência, ora a uma boa mãe, que nos acolhe nos seus braços." Hoje, porém, a terra maltratada e exaurida se lamenta e os seus gemidos se unem aos de todos os que se encontram abandonados e esquecidos pelo mundo.

\section{A Terra Clama Por Cuidado}

O Papa Francisco convida a escutar o clamor da terra e dos abandonados, e a uma “conversão ecológica". O pontífice reconhece que se nota "uma crescente sensibilidade relativamente ao meio ambiente e ao cuidado da natureza, e cresce uma sincera e sentida preocupação pelo que está a acontecer ao nosso planeta.” (LS 19), legitimando um olhar de esperança que permeia toda a Encíclica e envia a todos uma mensagem clara e repleta de esperança: "A humanidade possui ainda a capacidade de colaborar na construção da nossa casa comum." (LS 13); “o ser humano ainda é capaz de intervir de forma positiva "(LS 58)

Para Boff (2012) a Terra é um organismo vivo e nós somos sua porção ciente e inteligente e por isso mesmo responsáveis por ela: "Não estamos fora e em cima dela, mas participando da rede de relações que envolve todos os seres, para o bem e para o mal. Se poluo o ar, acabo adoecendo e afetando todos os demais seres vivos. Se recupero a mata ciliar do rio que passo em meu terreno, preservo as águas, colaboro para com o aumento de seu

\footnotetext{
${ }^{34}$ Laudato $\mathrm{Si}$ - Louvado sejas - sobre o cuidado da casa comum foi publicada em 18 de junho de 2015. É a segunda encíclica
} 
volume e melhoro minha qualidade de vida, dos pássaros e dos insetos que polinizam as árvores frutíferas e as flores do jardim.” (BOFF,2012, p.10)

A encíclica apresenta um caráter amplo e emergencial dirige-se aos católicos, mas também, a todos e todas que se sentem comprometidos e co-responsáveis pelo cuidado com a criação "especialmente entrar em diálogo com todos acerca da nossa casa comum" (LS 3): o diálogo percorre todo o texto, e no cap. 5 se torna o instrumento para enfrentar e resolver os problemas. Desde o início, o Papa Francisco recorda que também "outras Igrejas e Comunidades cristãs - bem como noutras religiões - se tem desenvolvido uma profunda preocupação e uma reflexão valiosa" sobre o tema da ecologia (LS 7).Desta forma o pontífice acolhe a todos indistintamente e valoriza a contribuição de cada ser, neste processo de cuidado com a mãe Terra.

O caminho no qual a Encíclica conduz é o de uma "ecologia integral, que inclua claramente as dimensões humanas e sociais" (LS 137), indissoluvelmente ligadas com a questão ambiental. Nesta perspectiva, o Papa Francisco propõe (cap. 5) empreender em todos os níveis da vida social, econômica e política um diálogo honesto, que estruture processos de decisão transparentes, e recorda (cap. 6) que nenhum projeto pode ser eficaz se não for animado por uma consciência formada e responsável, sugerindo ideias para crescer nesta direção em nível educativo, espiritual, eclesial, político e teológico, ou seja, que abranja todos os setores da vida humana.

Ao longo do capítulo 2 Francisco destitui o homem de seu egocentrismo, quando enfatiza que o ser humano não deve sentir-se o dono do universo, "não significa igualar todos os seres vivos e tirar ao ser humano aquele seu valor peculiar "que o caracteriza; "também não requer uma divinização da terra, que nos privaria da nossa vocação de colaborar com ela e proteger a sua fragilidade " (LS 90). Nesta perspectiva, "todo o encarniçamento contra qualquer criatura "é contrário à dignidade humana" (LS 92), porém, "não pode ser autêntico um sentimento de união íntima com os outros seres da natureza, se ao mesmo tempo não houver no coração ternura, compaixão e preocupação pelos seres humanos" (LS 91). Necessita-se da consciência de uma comunhão universal: “ criados pelo mesmo Pai, estamos unidos por laços invisíveis e formamos uma espécie de família universal, [...] que nos impele a um respeito sagrado, amoroso e humilde " (LS 89). Percebe-se que a tônica que perpassa pela tecedura de toda a encíclica são as temáticas do respeito, do diálogo e da mudança de consciência frente às questões que precisam ser enfrentadas, tanto sociais, ecológicas, econômicas e principalmente da relação humana com o planeta e com os seus semelhantes. 
Francisco denuncia que na época moderna há um excesso de antropocentrismo (LS 116): em que o ser humano está centrado exclusivamente em si mesmo e no próprio poder. Esta ideia alimenta a sociedade «descartável» que justifica todo tipo de descarte, ambiental ou humano que trata o outro e a natureza como um simples objeto com a finalidade de atender os desejos egocêntricos, o que conduz a variadas formas de dominação, levando à exploração infantil, abandono de idosos, programas escravistas de trabalho, tráfico de humanos, o comércio de peles de animais em risco de extinção e de "diamantes ensanguentados". É a mesma lógica de muitas máfias, dos traficantes de órgãos, do tráfico de drogas e do descarte e abandono de crianças porque não correspondem ao desejo de seus pais. (LS 123)

\begin{abstract}
Ficamos aflitos e inquietos ao verificar que as tentativas modernas de colectivização humana não têm outro resultado, contràriamente às previsões da teoria e à nossa expectativa, senão o rebaixamento e a escravidão das consciências. - Mas que caminho tomámos até hoje para nos unificarmos? Uma situação material a defender. Um novo domínio industrial a abrir. Condições melhores para uma classe social ou para nações desfavorecidas... Eis os únicos e medíocres terrenos em que temos tentado aproximarmo-nos.( TEILHARD DE CHARDIN, 1970, p. 264)
\end{abstract}

\title{
A Objetificação Do Ser Humano Na Sociedade De Consumo
}

No decorrer da encíclica, duas questões cruciais para o mundo de hoje são abordadas: a primeira o trabalho: "Em qualquer abordagem de ecologia integral que não exclua o ser humano, é indispensável incluir o valor do trabalho" (LS 124), bem como "renunciar a investir nas pessoas para se obter maior receita imediata é um péssimo negócio para a sociedade" (LS 128).A segunda refere-se aos limites do progresso científico, com clara referência aos OGM (LS 132-136), que são "uma questão de carácter complexo" (LS 135). Embora "nalgumas regiões, a sua utilização tenha produzido um crescimento económico que contribuiu para resolver determinados problemas, há dificuldades importantes que não devem ser minimizadas" (LS 134), a partir da "concentração de terras produtivas nas mãos de poucos" (LS 134). O Papa Francisco pensa em particular nos pequenos produtores e trabalhadores rurais, nos sem terra e sem lar, na biodiversidade, na rede de ecossistemas. Por isso ele conclama a "um debate científico e social que seja responsável e amplo, capaz de considerar toda a informação disponível e chamar as coisas pelo seu nome" a partir de linhas de pesquisa autónomas e interdisciplinares que possam trazer nova luz (LS 135).

No quarto capítulo o Papa chega ao coração da proposta da Encíclica, que é a ecologia integral como novo paradigma de justiça; ou seja, uma ecologia "que integre o lugar específico que o ser humano ocupa neste mundo e as suas relações com a realidade que o circunda" (LS 15). Isto engloba a todos, sem distinções, indiferente de vivermos em diferentes 
campos: na economia e na política, nas diversas culturas e até mesmo em cada momento da nossa vida cotidiana.

Para Francisco, a ecologia integral "é inseparável da noção de bem comum” (LS 156), a ser entendida, no entanto, de modo concreto: no contexto de hoje, no qual "há tantas desigualdades e são cada vez mais numerosas as pessoas descartadas, privadas dos direitos humanos fundamentais» comprometer-se pelo bem comum, significa fazer escolhas solidárias com base em «uma opção preferencial pelos mais pobres" (LS 158). Para o pontífice, esta é a melhor maneira para deixarmos um mundo sustentável às gerações futuras, não com belos discursos, mas através de um compromisso de cuidado dos pobres de hoje,

A vida diária, também é englobada pela ecologia integral com uma atenção particular ao ambiente urbano. O ser humano tem uma grande capacidade de adaptação e "admirável é a criatividade e generosidade de pessoas e grupos que são capazes de dar a volta às limitações do ambiente, $[\ldots]$ aprendendo a orientar a sua existência no meio da desordem e precariedade" (148). Porém, um desenvolvimento autêntico pressupõe um melhoramento integral na qualidade da vida humana: espaços públicos, moradias, transportes, etc. (LS 150-154).

O capítulo cinco traz algumas linhas de orientação e ação, com foco naquilo que podemos e devemos fazer. Conforme argumenta Francisco, “é necessário mais que análises sobre as questões emergenciais, é de grande importância que se gere propostas «de diálogo e de ação que envolvam, seja cada um de nós, seja a política internacional” (LS 15), e “ que nos ajudem a sair da espiral de autodestruição onde estamos a afundar” (LS 163). É preciso fugir do modo ideológico, superficial ou reducionista e buscar a construção de caminhos concretos, e para tal, é indispensável o diálogo, termo presente no título de cada seção deste capítulo.

Um ponto no qual o pontífice insiste ao longo do capítulo cinco, é sobre o desenvolvimento de processos de decisões honestas e transparentes, para poder 'discernir' quais políticas e iniciativas empresariais poderão levar "a um desenvolvimento verdadeiramente integral" (LS 185).

De acordo com que nos relata Boff $(2015)^{35}$ o texto e o tom da encíclica são típicos do papa Francisco e da cultura ecológica que ele acumulou. Mas, também, muitas expressões e modos de falar remetem ao que vem sendo pensado e escrito principalmente na América Latina. Os temas da "casa comum", da "mãe Terra", do "grito da Terra" e do "grito dos pobres", do "cuidado", da "interdependência entre todos os seres", do "valor intrínseco de

\footnotetext{
${ }^{35}$ A encíclica do Papa Francisco, por Boff: "Esperança e confiança no ser humano", Estadão, 22 de junho de
} 2015 
cada ser", dos "pobres e vulneráveis", da "mudança de paradigma", do "ser humano como Terra" que sente, pensa, ama e venera, da "ecologia integral", entre outros, são recorrentes no pensamento latino-americano.

No sexto e último capítulo é abordado a temática da educação e espiritualidade ecológicas, e atinge o cerne da conversão ecológica à qual a Encíclica convida. As raízes da crise cultural agem em profundidade e é preciso reformular hábitos e comportamentos. A educação e formação continuam sendo os desafios centrais: "toda mudança tem necessidade de motivações e dum caminho educativo" (LS 15); em que segundo o Papa, estão envolvidos todos os ambientes educacionais: " a escola, a família, os meios de comunicação, a catequese" (LS 213).

A temática aqui discutida abrange pois, questões atuais e de grande relevância, tanto no âmbito da Ciência da Religião como no âmbito das relações humanas e sociais. Além disso, a partir do momento que se pensa na possibilidade de analisar o cuidado integral com a criação, proposta esta feita pelo Papa Francisco na Laudato Si, abre-se uma nova janela para reflexão sobre qual o papel que cada ser humano tem no mundo? Quem ele é? Qual a sua essência e responsabilidade com o cuidado com a casa comum na qual ele também está inserido e é também morador?

Desta forma, o intuito principal deste estudo é resgatar um novo olhar sobre o cuidado com a criação e com as criaturas vista de forma integral, a fim de contribuir para a mudança de atitude do homem frente ao grito e lamento da mãe Terra e de seus filhos e quais ações já foram realizadas neste sentido além de lançar luz sobre possíveis atitudes na construção de um mundo mais humano, humanizante e humanizador.

\section{Considerações Finais}

Para Francisco "Uma ecologia integral é feita também de simples gestos quotidianos, pelos quais quebramos a lógica da violência, da exploração, do egoísmo" (230). Tudo isto será mais fácil a partir de um olhar contemplativo que vem da fé: "O crente contempla o mundo, não como alguém que está fora dele, mas dentro, reconhecendo os laços com que o Pai nos uniu a todos os seres. Além disso, a conversão ecológica, fazendo crescer as peculiares capacidades que Deus deu a cada crente, leva-o a desenvolver a sua criatividade e entusiasmo" (LS 220).

Em sentido geral, esta pesquisa buscou analisar a encíclica Laudato Si, promulgada por Francisco em 09/06/2015, e de que forma os assuntos nela tratados confluem com a 
realidade que vivenciamos na atualidade. Além disto, buscou-se fazer um paralelo das propostas expostas por Francisco, com o pensamento trazido pelo teólogo brasileiro Leonardo Boff, o qual desenvolveu e desenvolve uma vasta literatura sobre a compreensão cósmica integral do homem e do universo.

$\mathrm{O}$ artigo teve como principal objetivo tocar em temas nevrálgicos da sociedade atual, tais como: consciência ecológica, capitalismo, consumismo, degradação ambiental, sustentabilidade, egocentrismo, antropocentrismo, relações de dominação e poder, questões de exclusão social e econômica além de buscar clarificar quais ações são necessárias para a mudança de rota destes tortuosos caminhos pelo qual a humanidade caminha.

Faz-se necessário nos dias atuais, a busca de um exame de consciência, que inclua além de uma orientação para a própria vida, uma nova e importante dimensão, que extrapola a relação com Deus, com os outros e consigo mesmo, mas que também abarca a comunhão com todas as criaturas e com a natureza, conforme propõe o Papa Francisco na Laudato Si: "Como obra de misericórdia espiritual, o cuidado da casa comum requer 'a grata contemplação do mundo'. Como obra de misericórdia corporal, o cuidado da casa comum requer aqueles 'simples gestos quotidianos, pelos quais quebramos a lógica da violência, da exploração, do egoísmo' e se manifesta o amor 'em todas as ações que procuram construir um mundo melhor"'.

Desta forma, a reflexão acerca do tema do cuidado é lançada como um convite a todo cristão e a toda pessoa de boa vontade, que se sinta participante da integralidade da criação e de sua responsabilidade junto à criação e às criaturas, numa atitude de entrega e de ação junto às inúmeras injustiças e descasos que hoje se percebe pela obra divina. A encíclica por fim reaviva esta mensagem já difundida por Francisco de Assis e hoje ressoada na voz do Papa, e que encontra na teologia da libertação o suporte necessário na difusão de um olhar ecológico do mundo, ouvindo o clamor do povo e o grito da Gaia, que sangra e geme por cuidado.

\section{Bibliografia}

ALIER, Joan Martínez. O Ecologismo dos Pobres. São Paulo: Contexto, 2007.

BOFF, Leonardo. A encíclica do Papa Francisco, por Boff: "Esperança e confiança no ser humano", Estadão, 22 de junho de 2015.

BOFF, Leonardo. Cuidar da Terra, proteger a vida. Rio de Janeiro: Record, 2010. Direitos do coração: como reverdecer o deserto. São Paulo: Paulus, 2015. Ecologia- Grito da terra, grito dos pobres. $3^{\mathrm{a}}$ ed São Paulo: Ática, 1995. Ecologia, mundialização e espiritualidade. $2^{\mathrm{a}}$ ed Rio de Janeiro: Record, 2008. Ethos mundial - consenso mínimo entre os humanos. Rio de Janeiro: Sextante, 2001. 
Ética da vida. Rio de Janeiro: Record, 2009.

Ética e ecoespiritualidade. Petrópolis: Vozes, 2011.

O Tao da Libertação. ${ }^{2}$ ed. Petrópolis, RJ: Vozes, 2012.

O destino do homem e do mundo. 12 ${ }^{\mathrm{a}}$ ed. Petrópolis: Vozes, 2012.

.O cuidado necessário: Na vida, na saúde, na educação, na ecologia, na ética e na espiritualidade. Petrópolis, RJ: Vozes, 2012.

O evangelho do Cristo Cósmico. Rio de Janeiro: Record, 2008.

Principio Terra - a volta à Terra como pátria comum. São Paulo: Ática, 1995.

Opção Terra. Rio de Janeiro: Record, 2009.

Vozes, 2014.

Saber cuidar: ética do humano - compaixão pela terra. $20^{\text {a }}$ ed. Petrópolis, RJ:

Virtudes para um outro mundo possivel, vol. I: hospitalidade: direito e dever de todos. Petrópolis, RJ: Vozes, 2005.

Virtudes para um outro mundo possível, vol. II: convivência, respeito e tolerância. Petrópolis, RJ: Vozes, 2006.

Virtudes para um outro mundo possível, vol. III: comere beber juntos e viver em paz. Petrópolis, RJ: Vozes, 2006.

CHARDIN, Pierre Theilard. O fenômeno humano. Coleção Filosofia e Religião. Livraria Tavares Martins: Porto, 1970

Carta da Terra, Rio de Janeiro, 1992.

FRANCISCO, Papa. Laudato Si - Louvado sejas - sobre o cuidado da casa comum-

Documentos do Maagistério. Paulus: São Paulo, 2015.

GIRAUD, Gaël; ORLIANGE, Philippe. Laudato Si' e os Objetivos de Desenvolvimento Sustentável: uma convergência? Agence Française de Développment (AFD) Paris, França Tradução: Vanise Dresch. Instituto Humanitas Unisinos, ano XIII, número 117, vol. 13, 2016. Jornal da Arquidiocese do Rio de Janeiro. Testemunho de Fé, 'Laudato Si e as Grandes Cidades': um debate sobre o futuro da Casa Comum Rio de Janeiro: 23-29 de Julho 2017.

KERBER, Guillermo. O Ecológico e a Teologia Latino-Americana. Porto Alegre: Sulina, 2006.

LIPOVETSKY, Gilles. A era do vazio: ensaios sobre o individualismo contemporâneo. Barueri: Manole, 2005.

MURAD, Afonso. Ecoteologia: um mosaico, São Paulo: Paulus, 2016.

MURAD, Afonso; TAVARES, Sinivaldo Silva (orgs.). Cuidar da casa comum: chaves de leituras teológicas e pastorais da Laudato Si. São Paulo: Paulinas, 2016.

PAULA, Deborah Terezinha de. Entrevista concedida por e-mail à IHU On-Line em 27 de Junho 2015.

PASSOS, João Décio (orgs.). Diálogos no interior da casa comum: recepções interdisciplinares sobre a encíclica Laudato Si. São Paulo: Paulus, 2016.

RIBEIRO, Allan e SOMENSARI, André. Jornal Santuário, em Notícias: Campanha da Fraternidade reforça o cuidado com a casa comum. Brasília, 24 de fev 2017.

SUESS, Paulo. Dicionário da Laudato Si. São Paulo: Paulus, 2017.

TAVARES, S. Sinivaldo; A transparência divina na trama da criação. Rev. Pistis Prax. Teol. Pastor., Curitiba, v. 1, n. 2, p. 339-354, jul./dez. 2009. 


\title{
Catolicismo no Brasil e sua proposta de reforma agrária: as contribuições da doutrina social na elaboração de soluções para o problema agrário
}

\author{
Catholicism in Brazil and its proposal for agrarian reform: the contributions of social \\ doctrine in the elaboration of solutions to the agrarian problem
}

\author{
Nilmar de Sousa Carvalho ${ }^{36}$ \\ nilmarcarv@hotmail.com
}

\begin{abstract}
Resumo: Na segunda metade do século XX, o Brasil sofreu profundas transformações sociais no meio rural. A luta pela posse e uso da terra, aos poucos, foi se tornando um tema inevitável. Esse debate reverberou com a volta do país ao regime democrático, após o fím da II Guerra Mundial. O setor progressista da Igreja Católica, preocupado com essa questão, elaborou uma proposta de reforma Agrária que teve início em setembro de 1950, com a convocação da I Semana Ruralista pelo bispo de Campanha (MG), Dom Inocêncio Engelke. Durante os anos que se seguiram, a discussão ganhou mais relevância com o apoio da Conferência Nacional dos Bispos do Brasil (CNBB). Em 1956 e 1959, os bispos do nordeste endossaram esse debate com um discurso que defendia o desenvolvimento. Durante o governo de João Goulart (1961-1964), foi aprovado o estatuto do trabalhador rural e a Igreja apoiou as Reformas de Base.
\end{abstract}

Palavras-chave: Igreja Católica, reforma agrária, propriedade privada, Doutrina Social da Igreja.

Abstract: In the second half of the twentieth century, Brazil suffered profound social transformations in the rural environment. The struggle for possession and use of the land gradually became an inevitable theme. This debate reverberated with the return of the country to the democratic regime after the end of World War II. The progressive sector of the Catholic church, concerned about the need to find a solution to the problem, is prepared to reflect on the subject. In september 1950, the campaign Bishop (MG) D. Innocent Engelke summoned the I ruralist week. During the years that followed, the discussion gained more relevance, with the support of the National Conference of Bishops of Brazil (CNBB). This reflection culminated in the elaboration of a proposal for agrarian reform, defined as a political-social initiative. during the government of João Goulart (1961-1964), the church supported the Basic Reforms.

Key words : Catholic Church, Agrarian Reform, Private Property, Church Social Doctrine.

\section{Introdução}

Esse artigo pretende analisar a proposta de reforma agrária elaborada pela Igreja Católica entre os anos de 1950 e 1964. Procurará apresentar o contexto histórico da época, além dos pressupostos sócio-políticos e religiosos que levaram a Igreja Católica a refletir sobre o problema agrário.

\footnotetext{
${ }^{36}$ Mestrando em Ciência da Religião pela UFJF - Bolsista CAPES - Graduado em História pela Universidade Católica de Petrópolis/RJ: UCP.
} 
Na segunda metade do século XX, o Brasil viveu profundas transformações sociais no meio rural. A luta pela distribuição de terra, já em curso em outros países, aos poucos foi se tornando um tema bastante discutido entre alguns movimentos da sociedade brasileira, principalmente, aqueles ligados a luta e a defesa dos direitos sociais.

Em setembro de 1950, o bispo de Campanha (MG), Dom Inocêncio Engelke convocou a I Semana Ruralista e foi publicado o primeiro documento, chamado de carta pastoral, com o título: Conosco, sem nós ou contra nós se fará a reforma rural. Em 1954, a Conferência Nacional dos Bispos do Brasil (CNBB), por meio do documento: a Igreja e a Reforma Agrária elaborou um conceito sobre o tema. Nos anos de 1956 e 1959, foi realizado no nordeste o encontro dos bispos do nordeste. A Igreja defendeu que o atraso econômico do país era resultado da ausência de políticas públicas efetivas que solucionassem os problemas do desabastecimento de água, além de garantir o acesso à terra aos trabalhadores rurais.

Em 1960 os bispos de Campos/RJ Castro Mayer e o bispo de diamantina/MG, Geraldo Proença Sigaud, juntamente com o professor Plínio de Oliveira, se posicionaram contrários à proposta de Reforma Agrária que estava sendo pensada pela CNBB e, para justificar as suas discordâncias, publicaram um livro com o título: Reforma agrária, problema de consciência. Durante o governo de João Goulart (1961-1964), algumas das reivindicações feitas pela Igreja foram atendidas, dentre elas foi criado, em 1962, a Superintendência da Reforma Agrária (SUPRA). No ano seguinte foi aprovado o Estatuto do Trabalhador Rural que tornava extensivos ao campo os direitos trabalhistas. Foi criada também, a Comissão Nacional de Sindicalização Rural (CONSIR). Diante das propostas de reforma defendida por João Goulart, a igreja Católica, por meio da Comissão Central da CNBB, declarou publicamente apoio e, em contrapartida o governo federal reconheceu o esforço da Igreja Católica e a urgência de apresentar uma solução para o problema agrário.

Para ajudar na compreensão do objeto dessa pesquisa será feita uma contextualização histórica com o objetivo de evidenciar que a proposta de reforma agrária apresentada pela Igreja possui uma relação com três acontecimentos históricos que ocorreram no final do século XIX e durante a primeira metade do século XX. O primeiro, diz respeito à publicação da Encíclica Rerum Novarum pelo papa Leão XIII (1891), que representou uma nova hermenêutica da realidade sócio-política e religiosa da Igreja Católica. O segundo fato se refere à inflexão da Igreja Católica após a separação entre Igreja/Estado no final do século XIX, que lhe garantiu mais liberdade de ação. Essa abertura da Igreja, como estratégia para se reposicionar diante dos desafios do mundo secularizado, contou com a atuação do arcebispo do Rio de Janeiro, Sebastião Leme (1921). Dom Leme promoveu uma maior participação dos 
leigos na construção do ideário católico no Brasil e fundou as ligas católicas, dentre elas a Juventude Agrária Católica. E por fim, o papel do Partido Comunista Brasileiro como protagonista da luta pela distribuição de terra e, o primeiro a apresentar para a sociedade um projeto de reforma agrária.

O estudo desse tema foi pouco explorado pela comunidade acadêmica. Em 1983, o sociólogo Abdias Vilar de Carvalho escreveu uma obra com o título: A Igreja Católica e a questão agrária, em que procurou pesquisar esse movimento dentro da Igreja Católica. Evidenciou os vários encontros realizados pela hierarquia católica com a participação do poder público e dos trabalhadores rurais ocorridos entre a década de 50 e início da década de 60. E, que tinham como propósito, promover uma ampla discursão concernente à urgência de apresentar para classe campesina uma proposta de reforma agrária.

Esse trabalho tem como objetivo, portanto, além de aprofundar a discursão iniciada anteriormente pelo sociólogo Abdias V. de Carvalho, almeja ressaltar o papel da Igreja Católica, que por meio da sua Doutrina Social, se predispôs a lutar ao lado dos trabalhadores rurais pela realização da reforma agrária. Apresentar uma percepção acerca do objeto sem a pretensão de que tenha um caráter conclusivo, mas que possa auxiliar novas pesquisas.

\section{A encíclica rerum novarum como uma nova hermenêutica da sociedade contemporânea.}

O primeiro fato histórico, que ajudará na compreensão das razões que levou a Igreja Católica a refletir sobre a necessidade de elaborar uma proposta de reforma agrária, foi a publicação da Encíclica Rerum Novarum pelo papa Leão XIII, no final do século XIX. Leão XIII percebeu que não era mais possível adiar o encontro entre a tradição cristã e as coisas novas trazidas pela contemporaneidade. O Pontífice sensibilizado pela situação de exploração do operariado urbano, resultado da revolução industrial na Europa, se propôs a estabelecer uma alternativa que pudesse nortear essa grave crise social, motivada pelos:

(...) progressos incessantes da indústria, os novos caminhos em que entraram as artes, a alteração das relações entre os operários e os patrões, a influência da riqueza nas mãos dum pequeno número ao lado da indigência da multidão, a opinião enfim mais avantajada que os operários formam de si mesmos e a sua união mais compacta, tudo isto, sem falar da corrupção dos costumes, deu em resultado final um temível conflito (RERUM NOVARUM, 1).

A Encíclica Rerum Novarum inaugurou uma nova fase da cultura ocidental, uma modalidade do magistério eclesial e uma nova época na História da Igreja. O explosivo nascer da era industrial e a consequente revolução socioeconômica caracterizaram a crise da cultura ocidental nos fins do século XIX. Representou um novo olhar da Igreja sobre a realidade social multifacetada protagonizada pela modernidade (TERRA, 1991, p. 347). 
Dentre os variados temas abordados pelo papa Leão XIII, por meio da Carta Encíclica Rerum Novarum, alguns possuem relações com o objeto dessa pesquisa. No parágrafo quarto da Carta Encíclica, o papa defendeu a necessidade de garantir a propriedade privada. Segundo o pontífice, "o fim imediato de quem exerce uma arte lucrativa é conquistar um bem que possuirá como próprio, tendo-se em vista, prover à sua sustentação e às necessidades da vida". E ainda, "o trabalhador espera do seu trabalho, não só o direito ao salário, mas ainda um direito estrito e rigoroso para usar dele como entender". Leão XIII defendeu, também, que o trabalhador mediante a redução das suas despesas e, consequentemente, a poupança de algum valor, pode adquirir uma porção de terra que, segundo ele, não é outra coisa senão o seu salário transformado (RERUM NOVARUM, 4).

O papa Leão XIII propôs que a razão do trabalho é garantir o acesso a propriedade como uma espécie de mediação para a vida. A aquisição de bens é fundamental para que o trabalhador conquiste uma vida digna e humana, apontado pelo papa, como aquilo que pode “prover à sua sustentação e as necessidades da vida". Na mesma perspectiva, o papa João XXIII (1958-1963), afirmou que "é necessário que aos trabalhadores se dê um salário que lhe proporcione um nível de vida verdadeiramente humana e que lhes permitam enfrentar com dignidade as responsabilidades familiares". Para ele, o acesso à propriedade estende-se não só aos bens de consumo, mas também aos meios de produção, ou seja, o trabalhador, além do direito ao salário, também é garantido a ele a liberdade de usá-lo como quiser, inclusive para a aquisição de bens, denominados de frutos digno do trabalho (ANTONCICH \& SANS, 1992, p. 159).

Outro espectro abordado por Leão XIII trata da apreensão da Igreja Católica com relação ao avanço das ideias anticristãs defendida pelo materialismo histórico. Para o pontífice, além de o socialismo negar a relevância da religião para a sociedade, não reconhecia a propriedade privada e, ainda, defendia o uso da violência como forma de resistência. Segundo o papa: “a conversão da propriedade particular em propriedade coletiva, tão preconizada pelo socialismo, não teria outro efeito senão tornar a situação dos operários mais difíceis, retirando-lhes a livre disposição do seu salário e roubando-lhes" (RERUM NOVARUM, 4).

O papa, portanto, afirmou que a supressão da propriedade privada lesa os justos direitos do trabalhador e, que o trabalhador tem o direito de ser proprietário mediante o justo salário (ANTONCICH \& SANS, 1992, p. 160). Quanto à violência que o socialismo poderia promover, Leão XIII afirmou que "semelhante teoria é injusta, por violar os direitos legítimos 
dos proprietários, viciar as funções do Estado e tender para a subversão completa do edifício social" (RERUM NOVARUM, 3).

A Carta Encíclica Rerum Novarum abordou, também, a necessidade dos operários de se organizarem em associações, isto é, em sindicatos, como forma de evitar a influência das falsas ideologias e, ao mesmo tempo, garantir a proteção dos trabalhadores contra as injustiças sociais. Para Leão XIII é urgente à necessidade dos trabalhadores "organizarem-se eles próprios e unirem as forças para poderem sacudir denodadamente um jugo tão injusto e tão intolerável" (RERUM NOVARUM, 34).

O papa reconheceu, portanto, que apesar das dificuldades, havia um grande número de católicos operários que se mantinham firmes na defesa dos deveres e na observação dos preceitos cristãos. Salientou também que esses "homens de grande mérito" se reuniam frequentemente em congresso, com o propósito de compartilhar mutuamente as suas ideias, unirem as suas forças e ordenarem programas de ação. Outros se ocupavam em formar corporações com as diversas profissões, com o objetivo de manter os postos de trabalho.

\section{A separação Igreja/Estado como um novo alvorecer da Igreja Católica.}

O segundo aspecto que possui relação com esse objeto de pesquisa, concerne ao processo de separação envolvendo a Igreja e o Estado. Em 1872, deflagrou, no Brasil Império, a chamada Questão Religiosa. O episódio envolveu os bispos Dom Vital Maria G. de Oliveira, Dom Antônio Macedo Costa e a maçonaria. Dom Vital, bispo de Olinda, promoveu uma série de atos contra a maçonaria. Sensibilizado com a questão, Dom vital recebeu apoio do bispo do Pará, Dom Antônio Macedo. Os maçons, insatisfeitos, apelaram ao Imperador, que por meio do regime de padroado ${ }^{37}$ mantinha a Igreja sob a sua jurisdição. Em 12 de julho de 1873, o Conselho do Estado atendeu o recurso da maçonaria e o Supremo Tribunal de Justiça condenou os bispos a quatro anos de prisão. Em 1875, o governo reconsiderou as condenações e concedeu-lhes um indulto, mas determinou que ficassem em perpétuo silêncio.

\footnotetext{
${ }^{37}$ A descoberta e a formação do Brasil colonial foram um empreendimento conjunto da Igreja Católica e da Coroa Portuguesa. As descobertas marítimas e a formação de novas colônias significavam trazer novas terras e novas almas. A Igreja concedeu à Coroa Portuguesa o controle virtual sobre a nova Igreja, como por exemplo, nomeação dos bispos, recolhimento e administração do dízimo, construção de novos templos, as comunicações eram enviadas antes a Lisboa e só depois a Roma, os documentos eclesiásticos eram aprovados pela Coroa, era prerrogativa da Coroa determinar a quantidade e qualidade dos missionários enviados ao Brasil ... Em contrapartida o padroado poderia favorecer o desenvolvimento da Igreja como instituição. Os objetivos da Igreja e da Coroa, portanto, eram virtualmente idênticos, conseguir estar presentes em todos os seguimentos da sociedade. Cf: SCHERER, Irineu Roque. Concílio Plenário na Igreja do Brasil: a Igreja no Brasil de 1900 a 1945. São Paulo: Paulus, 2014. p. 20.
} 
A Questão Religiosa foi "uma tentativa do Estado de manter suas prerrogativas em face da Igreja. Entretanto foi o grito de independência da Igreja em relação ao Estado". (SCHERER, 2014, p. 31-33).

Todavia, a separação Igreja/Estado provocou, na Igreja, uma ruptura políticoorganizacional. A Igreja Católica diante dessa inflexão política foi impelida a buscar novos caminhos e, consequentemente, estabelecer um novo modus operandi, tanto do ponto de vista institucional, quanto na maneira de se apresentar dentro da sociedade. Segundo a Carta Pastoral de 19 de março de $1981^{38}$, foi assegurada à Igreja Católica certa soma de liberdade como ele nunca logrou no tempo da monarquia (SCHERER, 2014, p. 37). Sendo assim, os bispos ganharam maior liberdade de ação, pois as decisões eclesiais passaram a não depender mais da chancela do Estado. Esse movimento de inovação tornou uma constante na vida do catolicismo no Brasil durante as décadas seguintes.

Nos idos de 1898, o papa Leão XIII convocou o primeiro Concílio Plenário LatinoAmericano. Teve início em maio de 1999 e foi realizado na cidade de Roma. Contou com a presença de 53 bispos, sendo onze do Brasil. Dentre os objetivos defendidos pelo Concílio, dois ganharam notoriedade, a defesa e a propagação da fé católica (SCHERER, 2014, p. 40). Durante a primeira metade do século XX, a Igreja Católica se preocupou em cumprir esses objetivos e uma série de mudanças foram implementadas, principalmente, aquelas pensadas pelo bispo Dom Sebastião Leme de Silveira Cintra.

Em 1921, Dom Sebastião Leme foi nomeado arcebispo-coadjutor do Rio de Janeiro, em função da saúde frágil do Cardeal Arcoverde. Como ponto de partida do seu trabalho missionário, adotou a política do papa Pio XI que visava, dentre outras coisas, a restauração da ordem cristã. Dom Leme se empenhou para fazer da Igreja uma grande força mobilizadora, capaz de regenerar a sociedade. (MATOS, 2011, p. 58-59).

Dom Leme se preocupou em desenhar um modelo de Igreja atuante e combativa. O bispo percebia que havia no Brasil certos fatores que favoreciam a criação de uma espécie de militância católica, com um viés voltado para questões sociais. Sendo assim, o projeto sóciopolítico de Dom Leme se dividiu em duas frentes de ação: uma aproximação com as novas classes sociais da época, nesse caso com a burguesia e sobre ela a preocupação de aumentar a

\footnotetext{
${ }^{38}$ Carta Pastoral de 19 de março de 1890, a primeira publicada em conjunto, pelo episcopado e, dirigida ao clero e aos fieis, em vista da perseguição sofrida por parte do governo em alguns setores. A redação foi por dom Macedo Costa, bispo do Pará. Época da separação entre a Igreja/Estado, estabelecido pelo decreto n ${ }^{\circ}$. 119-A do governo provisório da República dos Estados Unidos do Brasil. Cf: SCHERER, Irineu Roque. Concílio Plenário na Igreja do Brasil: a Igreja no Brasil de 1900 a 1945. São Paulo: Paulus, 2014. p. 69)
} 
influência da Igreja e, a atenção às escolas católicas, vista como instrumento por excelência dessa política (MATOS, 2011, p. 62).

Em 1921, Dom Leme, com a colaboração de Jackson Figueiredo, fundou o centro D. Vital com o propósito de discutir ideias, formando um círculo de cultura. No ano seguinte, fundou a revista, "A ordem", que tinha como incumbência combater as manifestações contrárias aos princípios cristãos, tanto no campo filosófico, quanto literário e ético. Com a morte de Jackson Figueiredo em 1937, Alceu amoroso Lima (Tristão de Ataíde) se tornou o novo líder dos leigos no Brasil (SCHERER, 2014, p. 76).

Com a preocupação de que a Igreja assumisse um papel efetivo no campo político, mas sem fundar um partido católico, Dom Leme fundou a Liga Eleitoral Católica (LEC). Uma instituição suprapartidária que respeitava a liberdade do voto, desde que, os fiéis votassem nos candidatos que se comprometessem em defender, algumas prerrogativas, vistas pela Igreja como imprescindíveis à prática cristã, dentre elas: a indissolubilidade do matrimônio e o ensino religioso facultativo nas escolas. Pela primeira vez as mulheres iriam votar no Brasil, assim, como incentivo para que elas participassem do processo eleitoral, foi criado a Juventude Feminina Católica (JFC) e a Ação Universitária Católica (AUC) (SCHERER, 2014, p. 79).

Em 1935, Dom Leme fundou a Ação Católica brasileira e, para viabilizar a realização das propostas defendidas por esse movimento, foram criados vários outros grupos, cada um com o seu objetivo específico de atuação: Juventude Agrária Católica (JAC), Juventude Estudantil Católica (JEC), Juventude Independente Católica (JIC), Juventude Operária Católica (JOC) e a Juventude Universitária Católica (JUC) (OLIVEIRA, 2016, p. 90s).

Após a morte de Dom Sebastião Leme, em 1942, o padre Helder Câmara foi transferido de Fortaleza para o Rio de Janeiro. Em 1947, foi nomeado assistente nacional da Ação Católica e, nos anos seguintes, assim como o seu predecessor, foi responsável por um forte dinamismo, dentro e fora da Igreja em função da sua presença na sociedade mais ampla (SOUZA, 2004, p.78). Vale ressaltar que, nesses anos, a Igreja esteve envolvida nas discursões sociais por meio dos seus bispos, como p. ex., 1950, Dom Inocêncio Engelke, ligado à Juventude Agrária Católica convocou a I Primeira Semana Ruralista. 


\section{O partido comunista brasileiro como o primeiro movimento de resistência ao modelo latifundista.}

O terceiro acontecimento histórico, definido como aquele que impeliu a Igreja Católica a se "antecipar a revolução", se referiu ao papel do Partido Comunista Brasileiro como protagonista na luta pela distribuição de terra. $\mathrm{O}$ retorno do país ao regime de garantias democráticas, a partir de 1945, propiciou uma grande mobilização de massas camponesas, então marginalizadas, pela ausência de políticas governamentais que garantissem aos trabalhadores rurais, o acesso à terra (MORAIS, 2012, p. 21).

Os militantes do PCB, sob a liderança de Luís Carlos Prestes, entre 1945 e 1947, realizaram uma grande mobilização de trabalhadores rurais em quase todos os Estados brasileiros. Foram fundadas as chamadas ligas camponesas com intuito de organizar os lavradores. Os êxitos alcançados foram de tal importância que nem os elevados índices de analfabetismo do meio rural impediram a eleição de considerável número de representantes comunistas para as assembleias estaduais e municipais (MORAIS, 2012. p. 23).

O PCB foi o primeiro movimento social a discutir a urgência de políticas públicas que assegurassem, aos trabalhares rurais, o direito à terra. Em 1946, o partido inferiu duras críticas à nova Carta Constitucional por não apresentar um plano efetivo que atenuasse o problema do monopólio da terra. Esse acontecimento, levou o PCB a elaborar o primeiro projeto de reforma agrária. Em agosto de 1950, durante o chamado "manifesto de agosto", o partido defendeu o "confisco das grandes propriedades latifundiárias sem indenização, a entrega das terras diretamente aos camponeses e a abolição de todas as formas semifeudais de exploração da terra" (RODRIGUES, 1983, p. 414). O movimento acreditava que a causa do atraso econômico do país estaria fundamentado na propriedade privada e na sua concentração nas mãos de uma minoria (STEDILE, 2012, p. 12).

Adotando um discurso de ordem que propôs a realização da reforma agrária na "lei ou na marra", o PCB provocou no meio rural, um clima de tensão social que tendia para a deflagração de um conflito entre camponeses e fazendeiros. Diante dessa postura revolucionária do $\mathrm{PCB}$, a Igreja Católica também se predispôs a elaborar uma proposta de reforma agrária. 


\section{A proposta de reforma agrária da Igreja Católica (1950-1964).}

Na segunda metade do século XX, o Brasil sofreu profundas transformações sociais no meio rural. A luta pela distribuição de terra, já em curso em outros países ${ }^{39}$, aos poucos foi se tornando um tema inevitável entre os diferentes grupos da sociedade, de um modo especial, no meio político. Esse debate reverberou com a volta do país ao regime democrático, logo após o fim da Segunda Guerra Mundial (MORAIS, 2012, p. 21).

A Igreja Católica propôs uma reflexão sobre a Reforma Agrária num momento em que as definições acerca do tema, eram, ainda, incipientes. Em um período histórico marcado por um contido e limitado temor de questionar o direito de propriedade e os direitos dos latifundiários. Falar sobre esse tema se constituía uma espécie de antecipação preventiva, derivada de um claro antagonismo ideológico em relação às chamadas esquerdas e, do medo de que fosse instaurado, no Brasil, o regime socialista (MARTINS, 2004, p. 95).

A proposta Católica de Reforma Agrária foi fruto de vários encontros realizados pela Igreja Católica na década de 50 e início da década de 60. O primeiro ficou conhecido como: I Semana Ruralista, convocada pelo bispo diocesano de Campanha (MG), Dom Inocêncio Engelke $^{40}$, ligado a Juventude Agrária Católica, em 10 de setembro, de 1950. Contou com a participação de 60 párocos, 250 fazendeiros e mais de 270 professoras rurais. Os resultados dos debates deram origem à carta pastoral: Conosco, sem nós ou contra nós se fará a reforma rural. O Documento sugeriu que os camponeses formassem seus próprios líderes: "vendo sair de seus próprios meios os apóstolos de uma redenção social e cristã, o mundo agrícola tomará consciência do importante papel que exerce no seio da comunidade" e, propôs que o poder público estendesse ao trabalhador rural as garantias sociais já concedidas ao operariado urbano (ENGELKE, 1977, p. 46).

No ano seguinte, e contando com a assinatura de 113 bispos, um novo documento foi elaborado com o título: Ante os problemas atuais. Os bispos ratificaram as posições/opiniões defendidas pela carta pastoral do bispo de Campanha e defenderam que “a Igreja Católica não poderia ser indiferente à discussão da reforma agrária”. Além do

\footnotetext{
${ }^{39}$ A revolução chinesa de 1949 tinha como um dos pressupostos encontrar uma solução para o problema agrário.

${ }^{40}$ Dom Inocêncio Engelke nasceu em 11 de março de 1881, na cidade de Joinville (SC). Em 1924, foi nomeado Bispo Titular de Trapezópolis e Coadjutor de Dom Ferrão, em Campanha. Foi sagrado Bispo por Dom João Francisco Braga em 22-01-1925, tomando posse da Diocese no dia seguinte. Em seu episcopado em Campanha, realizou muitas obras de vulto, destacando-se a construção de um novo prédio para o Seminário Diocesano. Cf: http://www.diocesedacampanha.org.br/portal/index.php/diocese/antigos-bispos-e-administradores/30-conteudoestatico-portal/antigos-bispos-e-administradores/83-dom-inocencio-engelke-ofm-2-bispo-diocesano-1935-a1960. Acesso em 17 de nov; 2018.
} 
mais, esse documento assinado pelos 113 bispos, enalteceu o direito individual e social da propriedade como condição imprescindível para a manutenção da estabilidade social e da família (CARVALHO, 1983, p. 84).

Como ação prática, o documento sugeriu os chamados: princípios rurais, que previam o incentivo ao emprego de métodos cooperativos, tendo em vista o aumento da produção agrícola; mudanças na legislação trabalhista e na previdência social e, que as mesmas contemplassem também os trabalhadores rurais e o fomento de programa especial, referente à escola secundária, com técnicas de artes liberais destinadas a atender às necessidades das comunidades rurais (PORPHIRIO, 2015, p. 5).

Em setembro de 1954, a II Assembleia Geral da Conferência Nacional dos Bispos do Brasil $(\mathrm{CNBB})^{41}$ lançou o primeiro documento, elaborado pela Igreja Católica, sobre o tema: A Igreja e a reforma agrária. Por meio desse documento se estabeleceu o seu conceito de reforma agrária, definida como:

(...) um conjunto de medidas que modificam o atual estatuto jurídico-social da propriedade rural no sentido de vincular o homem à terra como seu proprietário; possibilitar em larga escala o acesso à terra àqueles que estejam aptos a se tornar proprietários; sendo assim, possa criar as condições para que o homem obtenha pela posse e uso adequado da terra, os meios de proporcionar uma existência digna de si e à família, sem ferir as legitimas exigências do bem comum (A IGREJA E A REFORMA AGRÁRIA, 1976, p.79).

Em 1956, os bispos do nordeste se reuniram na cidade de Campina Grande (PB) e, em 1959, na capital do Rio Grande do Norte. Desses dois encontros, foi elaborado um documento com o título: Declaração dos bispos do nordeste. O objetivo dessas assembleias foram debater os problemas de ordem social suscitados pela seca e pelas condições de vida dos trabalhadores rurais. A Igreja defendia que esses problemas provinham da ausência de desenvolvimento econômico nessa região e, por conseguinte, da incapacidade das economias atrasadas de romper o círculo vicioso da pobreza do campo. Nesse sentido, acreditava que a elaboração de uma política pública, que fomentasse a distribuição de riqueza, resultaria na minimização dessas calamidades, além de criar as condições necessárias para que os trabalhadores permanecessem inseridos no meio rural, evitando o êxodo de milhares de nordestinos para outras regiões do país (CARVALHO, 1985, p. 91). A Igreja entendia como desenvolvimento, a constituição de uma economia

\footnotetext{
${ }^{41}$ A CNBB foi criada, em 1952e dedicou-se aos estudos sobre os mais relevantes pontos da realidade brasileira da época, como a reforma agrária, a postura da instituição perante a opinião pública e as influências das estruturas sociais na vida religiosa do povo brasileiro. Inicialmente havia poucas assembleias que reuniam apenas os cardeais e os arcebispos, o que dificultava a criação de laços fraternos entre eles e a formação de um rosto próprio da Igreja no Brasil. Cf: BEOZZO, José Oscar. História da Igreja no Brasil. Petrópolis: Paulinas, 1985.
} 
harmônica, suficientemente autônoma, não submetida ao livre jogo das trocas internacionais, comandada pelos ciclos dos países economicamente dominantes e pela política egoísta dos monopólios (LIMA, 1979, p. 87).

Para Martins (1989), o Documento elaborado pelos bispos do nordeste tinha uma linguagem técnica, com indicação de diagnósticos econômicos e soluções, centrado na noção de progresso, com amplas recomendações favoráveis à modernização técnica, aos investimentos de capital e a modificação das estruturas econômicas. Além do mais, é uma posição explícita da Igreja pelo desenvolvimento econômico, como saída para o atraso, a pobreza e a economia agrária tradicional e latifundista. Segundo Martins:

(...) essa concepção moral de desenvolvimento servirá, nos anos seguintes, como parâmetro crítico para a avaliação pastoral das condições de vida do povo brasileiro por parte da igreja. Será a ideia elemento que permitirá o avanço da consciência e da postura crítica de religiosas, sacerdotes e bispos no confronto de uma realidade social de conflitos, violência e expropriação. (...), mas, se antes a motivação tinha uma raiz conservadora, em defesa da ordem, agora a raiz era outra: tratava-se de promover uma entrada maciça dos trabalhadores rurais no moderno mundo capitalista, basicamente no mundo da igualdade jurídica e dos direitos civis (MARTINS, 1989, p. 45).

Em dezembro de 1960, o episcopado paulista sob a orientação de D. Carlos C. de Vasconcelos Motta, com o apoio do presidente da CNBB, Dom. Helder Câmara e do Núncio Apostólico $^{42}$, apoiou o projeto de Reforma Agrária, apresentado pelo governador do Estado de São Paulo, Carvalho Pinto, denominado de Revisão Agrária. Os bispos afirmaram que as propostas apresentadas pelo governo paulista encontram bases na Rerum Novarum. E, assim como defendeu D. Inocêncio Engelke, seria urgente à defesa da propriedade privada no campo, a necessidade do cooperativismo, salários justos, moradias dignas para o trabalhador do campo e a previdência social (TOLENTINO, 2011, p. 99).

Em 1960, o professor Plínio de Oliveira, juntamente Dom Castro Mayer, bispo de Campos (RJ) e, dom Geraldo Proença Sigaud, bispo de Diamantina (MG) se posicionaram contrários à proposta de Reforma Agrária que estava sendo pensada pela CNBB e, para justificar as suas discordâncias, publicaram um livro com o título: Reforma agrária, problema de consciência (SOUZA, 2004, p.79).

\footnotetext{
${ }^{42}$ Em setembro de 1954, Dom Armando Lombardi foi designado a assumir a nunciatura no Brasil pelo subsecretário de Estado do Vaticano, Giovanni Battista Montini (futuro papa Paulo VI) com a seguinte recomendação: "No Brasil, você terá muitos amigos, mas seu amigo deverá ser monsenhor Câmara". Ele se tornou um grande incentivador do processo de renovação interna da Igreja que vinha ocorrendo desde os anos finais da década de 40. Cf: LUNA, Luís Henrique de Oliveira. As Relações entre o Núncio Apostólico no Brasil e o Arcebispo de Olinda e Recife, durante os Primeiros Anos do Regime Militar (1964-1969). Disponível em: http://www.abhr.org.br/wp-content/uploads/2013/09/19.-As-Rela\%C3\%A7\%C3\%B5es-entre-o-

N\%C3\%BAncio-Apost $\%$ C3\%B3lico-no-Brasil-e-o-Arcebispo-de-Olinda-e-Recife-Durante-os-.htm. Acesso em: 17 de nov. 2018
} 
Segundo os seus autores, o Brasil vivia uma crise de produção, de transporte, de finanças etc. Entretanto, as atenções estavam mais voltadas para os problemas do campo, "por toda parte se fala em reforma agrária". Havia uma atmosfera de confusão no estudo da reforma agrária. Em meio a essa confusão, percebia-se uma espécie de resistência contra o proprietário rural e contra o direito de propriedade. Para eles, o papel da propriedade rural, grande e média, no conjunto da economia nacional, é um privilégio pessoal. Eles reconheciam que havia na sociedade o desejo mais ou menos consciente de aboli-las, mediante pequena indenização. Eles percebiam que debates sobre essa proposta de reforma agrária estavam induzindo as pessoas a adotarem programas socialistas e revolucionários. Diante dessa realidade, os bispos Dom Castro Mayer e Dom Geraldo Proença Sigaud admitiam que haviam riscos, caso fosse aprovada qualquer legislação nesse ambiente de irreflexão. Para eles, a propriedade, ao invés de ser protegida, poderia ser cerceada. Se isso acontecesse, o Brasil passaria por uma grave crise de consciência histórica (MAYER, SIGAUD, OLIVEIRA, 1960, p. 2).

Com o acirramento do embate político, durante o governo de João Goulart (19611964), a Igreja, por meio da Comissão Central da CNBB, declarou publicamente apoio às propostas do governo, que ficaram conhecidas como: Reformas de Base, que defendiam, dentre outras mudanças, a realização da distribuição de terras. A Comissão Central da CNBB, reunida nos dias 13 e 14 de julho de 1962, procurando interpretar o pensamento do episcopado, em face da presente situação do Brasil, julgou de seu dever levar à nação uma palavra de esclarecimento e um apelo:

\section{Poderemos promover as chamadas Reformas de Base, reclamadas por todos e de urgência inadiável (...). Daí saudarmos, com alegria, as Reformas de Base que passaram a ser anseio de todos os responsáveis - poderes da República, partidos políticos, classes dirigentes (MENSAGEM DA COMISSÃO CENTRAL DA CNBB, 1976, p. 99s).}

Entretanto, a realização da reforma agrária dependia da aprovação, pelo Congresso Nacional, de uma emenda constitucional que autorizava a desapropriação de terras por interesse social, com indenizações pagas com títulos da dívida pública, contrária à resolução contida na Carta Constitucional de 1946, que determinava que as indenizações fossem pagas em dinheiro (MARTINS, 1984, p. 21).

Por meio do Decreto Legislativo em 1962, foi criada a Superintendência da Reforma Agrária (SUPRA), com o objetivo de ativar medidas preparatórias de reforma antes mesmo de sua aprovação pelo Congresso, visando criar condições políticas e institucionais favoráveis à sua imediata aplicação. No ano seguinte, o Congresso Nacional aprovou o Estatuto do 
Trabalhador Rural, que tornava extensivos ao campo o direito que os trabalhadores urbanos já haviam incorporado décadas antes, como a obrigatoriedade do registro em carteira profissional, salário mínimo, repouso semanal, férias remuneradas (NATIVIDADE, 2011, p. 7). Foi criada, também, a Comissão Nacional de Sindicalização Rural (CONSIR), com a incumbência de promover a formação de lideranças rurais e flexibilizar os trâmites legais para a criação de sindicatos. No ano de 1963, o número de sindicatos rurais no Brasil saltou de 50, para mais de 700 (BALTHAZAR, 2014, p. 4).

A Proposta de Reforma Agrária, elaborada pela Igreja Católica, teve um papel central para a política agrária, contida nas Reformas de Base do presidente João Goulart. Segundo Lucília Delgado, o discurso do presidente Goulart ${ }^{43}$ se mostrou, por vezes, em consonância com os princípios defendidos pela Igreja Católica, como ficou explícito no trecho:

(...) o papa João XXIII nos ensina, que a dignidade da pessoa humana exige como fundamento natural para a vida, o direito e o uso dos bens da terra, ao qual corresponde a obrigação fundamental de conceder uma propriedade para todos. É dentro desta autêntica doutrina que o governo brasileiro vem procurando situar sua política social, particularmente no que diz respeito a nossa realidade agrária (DELGADO, 2001, p. 167).

Houve, portanto, uma aproximação entre a Igreja Católica e o projeto político do governo federal, que reconheceu nos princípios morais cristãos, os fundamentos norteadores desse processo que deveria culminar com a realização da reforma agrária.

\section{Considerações Finais}

A proposta de reforma agrária, elaborada pela Igreja Católica, pode ser considerada um desfecho possível, dentro daquilo que a ala mais progressista havia se predisposto a realizar. Existia um clamor pela realização de um projeto político que atenuasse o problema agrário. A Igreja se propôs a encontrar um caminho possível e, ao mesmo tempo, como afirmou o bispo de Campanha, antecipar "a revolução".

Todavia, não podemos entender essa postura da Igreja nesse momento histórico, se prescindirmos da análise de sua trajetória histórica. Sem considerarmos a relevância dos eventos historiográficos descritos e sem reconhecer, nos mesmos, as suas especificidades que, de alguma forma, justificaram a sua intenção de se juntar aos trabalhadores rurais em prol da distribuição de terras.

\footnotetext{
${ }^{43}$ Discurso realizado na Central do Brasil em 13 de março de 1964.
} 
A Igreja tinha consciência que a realização das suas reivindicações dependia do poder estatal, por isso procurou manter uma boa relação com os governos federais desse período. Como ação concreta, podemos destacar a criação da Superintendência de Desenvolvimento do Nordeste no governo do presidente JK, a aprovação do Estatuto do Trabalhador Rural, a criação da Superintendência da Reforma Agrária e a questão agrária que se transformou em prioridade pelo projeto denominado Reforma de Bases do presidente João Goulart.

\section{Fontes}

A IGREJA E A REFORMA AGRÁRIA. Conclusões Gerais da II Assembleia Ordinária da CNBB. In CNBB, Pastoral da Terra, Ed. Paulinas, (Estudos da CNBB 11), São Paulo, 1976.

ENGELKE, Dom Inocêncio. Conosco, Sem Nós ou Contra Nós se Fará a Reforma Rural. (MG 10/09/1950) In: Conferência Nacional dos Bispos do Brasil-CNBB. Pastoral da Terra (Estudos da CNBB 11. Antologia de Documentos e Pronunciamentos Pastorais). São Paulo: Edições Paulinas, 1977, p. 43-53.

LEÃO XIII. Rerum Novarum: sobre a condição dos operários. Disponível em: http://w2.vatican.va/content/leoxiii/pt/encyclicals/documents/hf_lxiii_enc_15051891_rerumnovarum.html. Acesso em 28 de set. 2018.

MENSAGEM DA COMISSÃO CENTRAL DA CNBB. In; CNBB, pastoral da Terra, Ed. paulinas. (Estudos da CNBB 11). São Paulo, 1976.

PROPOSTA DE REFORMA AGRÁRIA DA BANCADA DO PCB NA CONSTITUINTE DE 1946: In STEDILE, João Pedro (org.) e ESTEVAM, Douglas (assistente de pesquisa). $A$ Questão Agrária no Brasil: O Debate na Esquerda: 1946-2003. Expressão Popular, 2012. p. 12.

A IGREJA E A REFORMA AGRÁRIA. Conclusões Gerais da II Assembleia Ordinária da CNBB. In CNBB, Pastoral da Terra, Ed. Paulinas, (Estudos da CNBB 11), São Paulo, 1976.

\section{Referências Bibliográficas}

ANTONCICH, Ricardo \& SANS, José M. Munarriz. Ensino social da Igreja: a Igreja, Sacramento de Libertação. 3a Edição, Vozes: Petrópolis/RJ, 1992.

BALTHAZAR, Pedro Henrique Barbosa. Sindicalização Rural no Governo de João Goulart (1961-1964): As Discussões Historiográficas Acerca do Campo Brasileiro. In: Anais do XVI Encontro Regional de História da ANPUH-RIO: Saberes e Práticas Científicas. 28 de julho a $1^{\circ}$ de agosto de 2014. p. 1-11.

CARVALHO, Abdias Vilar de. A Igreja Católica e a Questão Agrária. In: PAIVA, Vanilda (Org). Igreja e Questão Agrária. São Paulo; Edições Loyola. 1983. p. 68-103.

DELGADO, Lucília de Almeida Neves. Trabalhismo, Nacionalismo e Desenvolvimentismo: um projeto para o Brasil (1945-1964). In: FERREIRA, Jorge (org.). O Populismo e sua História: Debate e Crítica. Rio de Janeiro: Civilização Brasileira, 2001, p. 167-203.

LIMA, Luiz Gonzaga de Souza. Evolução política dos católicos e da Igreja no Brasil: hipótese para uma interpretação. Petrópolis RJ: Vozes, 1979. 
MAYER, Castro, SIGAUD, Proença, OLIVEIRA, Plínio. Reforma agrária, problema de consciência. Disponível em http://www.pliniocorreadeoliveira.info/livros/1960\%20\%20ReformaAgrariaQuestConci\%C3\%AAncia.pdf. Acesso em 18 de abr. de 2018.

MARTINS, José de Souza. Reforma Agrária: O Impossível Diálogo. São Paulo: Editora da Universidade de São Paulo, 2004.

Caminhando no Chão da Noite: Emancipação Política e Libertação Social do Campo. São Paulo: Hucitec. 1989.

- A Militarização da Questão Agrária no Brasil, (Terra e Poder:

O Problema da Terra na Crise Política). Petrópolis: Vozes, 1984.

MATOS, Henrique Cristiano José. Nossa história: 500 anos de presença da Igreja Católica no Brasil. $2^{a}$ edição, São Paulo: Paulinas, 2011.

MICELI, Sérgio. A elite eclesiástica brasileira. São Paulo: Companhia das letras, 2009.

MORAIS, Clodomir Santos de. História das ligas camponesas do brasil. In STEDILE, João Pedro (org.) e ESTEVAM, Douglas (assistente de pesquisa). A questão agrária no Brasil: $O$ debate na esquerda: 1954-1964. Expressão Popular, 2012. p. 21-70.

NATIVIDADE, Melissa de Miranda. A Questão Agrária no Brasil no Governo João Goulart: uma Arena de Luta de Classe e Intraclasse (1961-1964). In: Anais do XXVI Simpósio Nacional de História - ANPUH. São Paulo, julho 2011. p. 1-16.

OLIVEIRA, Alexandre Luís de. Dom Sebastião Leme e as estratégias de atuação do catolicismo nos anos 1930.In: Faces de Clio, Revista discente do programa de pós-graduação em História - UFJF. Vol. 2 | N. 4 | Jul./Dez. 2016. p. 88 -98.

PORPHIRIO, Max Fellipe Cesário. O Nordeste e o Campo Brasileiro, 1961. In: XXVIII Simpósio Nacional de História - Lugares dos Historiadores: Velhos e Novos Desafios, 27 a 31 de julho de 2015, Florianópolis/SC. p. 1-18.

RODRIGUES, Leôncio Martins. O PCB: Os dirigentes e a organização: In. FAUSTO, Boris. O Brasil Republicano: Sociedade e política (1930-1964). São Paulo: Difel, 1983.

SCHERER, Dom Vicente. Nossos problemas agrários e rurais. In: R.E.B., v. 22, fascículo 01, mar.1962, p. 234-236. Biblioteca Nacional (BN), cód. 2-136, 01,03.

SCHERER, Ireneu Roque. Concílio Plenário na Igreja do Brasil: a Igreja no Brasil de 1900 a 1945. São Paulo: Paulus, 2014.

SOUZA, Luiz Alberto Gómez de. As várias faces da Igreja Católica. In: Estudos avançados, v.18 n. 52; São Paulo Set./Dez. 2004. p. 77-95.

TERRA, João Evangelista Martins. A Rerum Novarum dentro de seu contexto sociocultural. In: Síntese Nova Fase, v. 18, n. 54. 1991, p. 347-366.

TOLENTINO, Célia Aparecida Ferreira. O Farmer contra o Jeca: o projeto de revisão agrária do governo Carvalho Pinto. São Paulo: Cultura Acadêmica, 2011. 


\section{A Igreja e a Pastoral Operária no ABC Paulista (1978 - 1988)}

The Church and the Pastoral Working in ABC Paulista (1978 - 1988)

Luiz Fernando Mangea da Silva mangea.1fms@gmail.com

Resumo: Na região do $\mathrm{ABC}$ Paulista pode ser historicamente considerada um núcleo de resistência da classe operária e da Igreja Católica no sentido de defender os interesses dos operários e ao mesmo tempo combater o autoritarismo do regime militar contra a classe trabalhadora no período de transição da ditadura militar para a redemocratização. Esses movimentos constituídos por católicos e operários da região do $\mathrm{ABC}$ Paulista defendiam não só melhores condições de trabalhos nas fábricas, mas também se engajaram publicamente em campanhas pela anistia e pela redemocratização do país.

Palavras-chave: Igreja Católica, Pastoral Operária, Movimento Operário no ABC.

Abstract: In the region of $\mathrm{ABC}$ Paulista can be historically considered a nucleus of resistance of the working class and the Catholic Church in order to defend the interests of the workers and at the same time combat the authoritarianism of the military regime against the working class In the transitional period of the military dictatorship for Redemocratization. These movements consisting of Catholics and workers from the ABC Paulista region defended not only better working conditions in the factories, but also publicly engaged in campaigns for amnesty and for the redemocratization of the country.

Key words: Catholic Church, Worker's Pastoral, Worker Movement in ABC.

\section{O pensamento social católico e as ações pastorais da Igreja no ABC Paulista}

Pensar na organização da Pastoral Operário será fundamental para a compreensão do significado da sua atuação nas lutas operárias e também para tentar reconstruir parte da história, sobretudo, daquela parcela de trabalhadores que vinculou sua prática política e social aos movimentos liderados pela Igreja no ABC.

O Concílio Vaticano II e sua recepção por bispos como Dom Cláudio Hummes fez com que emergisse nas periferias dos centros urbanos um novo sujeito social: os integrantes de pastorais sociais engajados em movimentos populares, ou seja, a participação ativa dos leigos dentro e fora da Igreja. Esse concílio apresentou uma enorme mudança na eclesiologia, à medida que enfatizou uma Igreja mais participativa e mais transversal em detrimento de uma Igreja vertical e hierarquizada.

A Igreja com suas dioceses e com suas paróquias passaram a ser apresentadas como comunidade de fé, de esperança e de amor aos pobres e oprimidos pelos sistemas políticos e 
econômicos da sociedade moderna. Por isso, que muitos bispos que participaram do concílio ou que nele se inspiravam para atuar em suas dioceses não aceitaram regimes políticos autoritários, despóticos, tirânicos ou sistemas econômicos que violasses a dignidade da pessoa humana. Ney de Souza explica que essa mudança na eclesiologia da Igreja após o concílio coloca a seguinte questão:

Assim como Jesus Cristo realizou sua missão na pobreza e na abnegação, também a Igreja é chamada a seguir o seu exemplo. Ela não foi constituída para alcançar poder e glória, mas para evangelizar os pobres, sarar os contritos de coração, procurar e salvar o que perecera: (Souza, 2015, p. 227-301)

O que se constata a partir dessa questão colocada por Ney de Souza é que a Igreja passou a se ver como uma instituição que poderia atuar na transformação religiosa e moral mundo contemporâneo. A década de 1970, a CNBB assumirá uma linha pastoral de forte intervenção social principalmente no tocante a defesa da dignidade da pessoa humana.

Os bispos do Nordeste lançam em 1973 do documento denominado "Eu ouvi os clamores do meu povo" e nesse mesmo ano os bispos do Centro Oeste produzem um fascículo denominado "Marginalização de um povo: um grito das Igrejas", no qual analisam a situação do povo marginalizada da sociedade brasileira. Assim que chegou à Diocese de Santo André, Dom Cláudio Hummes buscou reestruturar sua ação pastoral partindo desses documentos e do pensamento social da Igreja. O movimento operário do $\mathrm{ABC}$ passava por uma estruturação política e social por causa das perseguições durante o período da ditadura militar (1964-1985).

A política dos militares para o mundo do trabalho era de intervenção nos sindicatos, por meio do atrelamento destes ao Ministério do Trabalho, "manutenção do peleguismo", uso repressivo do aparato policial e da legislação sindical contra as greves. Além disso, havia outro problema social que estava relacionado com o campo, mas que interferia diretamente com os trabalhadores urbanos que era o êxodo rural.

A expropriação dos pequenos camponeses e posseiros forçava a migração de trabalhadores do campo para os polos industriais do país como a região do $\mathrm{ABC}$, casando um exército de reserva, isto é, ocorria um crescente número de desempregados. Para as empresas da região era importante porque facilitava o achatamento dos salários conforme podemos observar na tabela abaixo: 


\begin{tabular}{lc}
\hline Parte dos salários no valor do produto industrial \\
\hline $\mathbf{1 9 6 6}$ & $12,2 \%$ \\
$\mathbf{1 9 7 0}$ & $10,7 \%$ \\
$\mathbf{1 9 7 3}$ & $10,0 \%$ \\
$\mathbf{1 9 7 4}$ & $8,7 \%$ \\
\hline
\end{tabular}

Fonte: A política do grande capital: Encontro realizado no dia 6 de dezembro de 1980, no Centro de Formação de Líderes da Diocese de Nova Iguaçu, entre agentes pastorais e sindicalistas para debater as experiências da Pastoral Operária de São Bernardo do Campo. (p. 2).

A Pastoral Operária do Estado do Rio de Janeiro trocava com frequência experiência com a Pastoral Operária de Estado de São Paulo, principalmente, com a Pastoral Operária ABC. Nesse encontro, as pastorais da Baixada Fluminense (Duque de Caxias e Nova Iguaçu) e do Sul do Estado do Rio de Janeiro (Volta Redonda) buscaram debater os efeitos do grande capital sobre a classe trabalhadora brasileira.

Sendo assim, os agentes pastorais de Duque de Caxias, de Nova Iguaçu e de Volta Redonda foram buscar, nas experiências da Pastoral Operária do ABC, as diretrizes para atuarem juntos aos movimentos sindicais presentes suas cidades. A Pastoral Operária do ABC já havia consolidado uma experiência com o Sindicato dos Metalúrgicos de São Bernardo do Campo em um encontro patrocinado por este e pela Diocese de Santo André em julho de 1980.

O encontro entre a Pastoral Operária de São Bernardo do Campo e o Sindicato dos Metalúrgicos ocorreu nos dias 4, 5 e 6 de julho de 1980 na cidade de Taboão da Serra porque o Sindicato dos Metalúrgicos de São Bernardo do Campo estava sob intervenção da política repressiva da ditadura militar. Desse encontro saiu o famoso "Documento de São Bernardo" assinado por mais de cinquenta representantes do movimento sindical, do movimento popular e da Pastoral Operária. Nesse documento se destacou os seguintes assuntos:

- Relação sindical cidade-campo;

- Formas de colaboração e de união do movimento sindical outros movimentos populares;

- Relação entre partido político e movimento popular;

- Rumos prioritários do sindicalismo na cidade e no campo frente à conjuntura atual. 
Para a Igreja local e para o Sindicato dos Metalúrgicos de São Bernardo do Campo, a conjuntura política das décadas de 1970 e de 1980 era caracterizada pela política do grande capital que era o lucro das empresas. O achatamento dos salários e o aumento da produtividade gerando acumulação de capital contribuíam, ainda, mais para o aumento da taxa de lucro das empresas.

Essa relação intrínseca entre católicos e trabalhadores do campo e da cidade resultou em transformações relevantes no interior da Igreja, possibilitando o surgimento de diferentes concepções de missão, de vivência da fé e do evangelho, ou seja, do papel social e religioso da Igreja na sociedade. Quando olhamos para a atuação da Igreja, no ABC Paulista, percebemos que as transformações que se processavam nos movimentos de base, como a Pastoral Operária, eram a expressão das transformações ocorriam na sociedade brasileira em relação capital e trabalho.

Para os agentes da Pastoral Operária do ABC, o Brasil da década de 1980 era um país marcado por um problema estrutural uma vez que a dívida externa brasileira era de aproximadamente 60 bilhões de dólares, (com juros e amortização no valor de 14, 5 bilhões de dólares no ano de 1980).

O pagamento de juros para amortizar a dívida impossibilitava os investimentos públicos no campo social (hospitais, educação, saneamento básico, transportes dentre outros serviços). Pastoral Operária e movimento sindical compartilhavam uma visão em comum sobre essa situação social que o país vivenciava na década de 1980. Essa política beneficiava os patrões em detrimento da classe trabalhadora já que explorava a mão de obra barata do trabalhador brasileiro, o que dava ao patrão o seguinte taxa de lucro: "Taxa de lucro mundial: 4\%, taxa de lucro no Brasil 28\%”: (Política de investimento, 1980, p. 3).

As tensões e os conflitos que surgiam na região do $\mathrm{ABC}$ Paulista no que se refere capital e trabalho deveriam ser analisados sobre a luz da fé e do evangelho, e partindo sempre da atuação da Igreja na sociedade como uma instituição comprometida com a classe trabalhadora. Em contraposição à concentração de capital dos bancos e das grandes empresas.

Ao contrário da política econômica do capital monopolista, os trabalhadores têm sua política econômica não no lucro, mas no interesse social e na satisfação das necessidades das classes populares. Em outras palavras significa afirmar que: “A política econômica dos trabalhadores baseia-se na produção, distribuição e consumo": (Política de investimento, 1980, p. 4). A Igreja sacramental, comprometida com as classes dominantes, que havia apoiado o golpe militar de 1964 se transformava em uma Igreja voltada para base e para oprimidos, comprometida com a libertação das classes subalternas. 
O que a Pastoral Operária do ABC Paulista estava desenvolvendo junto à classe trabalhadora era uma ação pastoral de superação de uma Igreja assistencialista na qual a pessoa se comove diante do quadro de miséria coletiva. Em outras palavras, tratava-se de superar aquela ideia assistencialista da Igreja Católica, que função da pobreza coletiva, os católicos organizam-se obras assistenciais, como a sopa para os pobres, campanha do cobertor, chá beneficente, Natal da periferia ou fornecimentos de cestas básicas e remédios gratuitos.

Para os católicos engajado com o movimento operário essa ação pastoral da Igreja ajudava os indivíduos excluídos do processo de produção capitalista, mas também fazia deles objetos de caridade e nunca sujeitos de sua própria liberdade. Não se percebe que o trabalhador é um indivíduo explorado e oprimido por outros indivíduos que são os proprietários do modo de produção capitalista.

A Pastoral Operária nesse sentido cumpria o papel de valorizar aquilo que o trabalhador já possui intrinsecamente como a força da resistência, a capacidade de consciência de classe, de seus direitos, de organização e de transformação de sua situação política e social. O assistencialismo gera quase sempre uma dependência no operário porque estão atrelados à ajuda e à decisão de outras pessoas como, por exemplos, da hierarquia católica, diretores de empresas públicas, privadas ou diretores de sindicatos, impossibilitando assim do trabalhador de sujeito da sua própria libertação.

De acordo com o pensamento social da Pastoral Operária, são os trabalhadores que produzem toda a riqueza da sociedade capitalista. Sendo assim, será necessário que a produção esteja sob seu controle e planejamento dos trabalhadores. Pois, só assim que os operários vencem sua condição de explorado e elaboram estratégias mais adequadas de libertação.

Essas estratégias acontecem à medida que os trabalhadores e integrantes da Pastoral Operária se unem, entram em um processo de conscientização, descobrem as causas de sua exploração, organizam seus movimentos e agem de forma articulada para as transformações das relações sociais de dominação entre capital e trabalho. Essa articulação entre católicos e operários no ABC Paulista ocorreu dentro do período da abertura política, já que a ditadura militar não seria não dispunha de uma legitimidade social para manter o regime por meio da extensa exploração econômica dos trabalhadores e para fazer uso da repressão como força de dominação do operariado, sendo destacado por Mainwaring da seguinte forma: 
Durante esse período foi muito divulgado o trabalho pastoral dos bispos do Estado de São Paulo, onde dom Paulo Arns se torna o líder mais aparente. O documento de 1975 dos bispos de São Paulo, "Não Oprimas teu Irmão", surgiu logo após uma onda de repressão e foi uma das mais fortes, mais importantes declarações episcopais contra a tortura: (Mainwaring, 2004, p. 175).

Em vista disso, o governo do general Ernesto Geisel começou a articular um projeto de abertura política, mas que fosse "lenta", "gradual" e "segura" rumo à "democracia". Mas a crise econômica e a reação da "linha dura" do Exército colocariam permanentemente em cheque os planos de "distensão" o próprio Geisel não dava demonstração de que poderia ocorrer suspensão a repressão ao movimento operário. De acordo com Ricardo José Braga Amaral de Brito:

É neste momento que o movimento sindical reencontra a possibilidade a possibilidade de se reorganizar, mobilizando a luta salarial e o direito de greve. Apesar de ter como principal expoente o sindicato dos metalúrgicos no $\mathrm{ABC}$ paulista, o ressurgimento do movimento se expande a inúmeras categorias trabalhistas para além das fábricas, tendo como o ano 1978 uma data marcante para o surgimento do novo sindicalismo com as greves no ABC paulista: (Brito, 2014, p. 87-101).

Esse novo modelo de sindicalismo que se estabelecia no $\mathrm{ABC}$ fez com que Dom Cláudio Hummes se diferenciasse do seu antecessor, dom Jorge Marcos de Oliveira, no que se refere à atuação episcopal. Enquanto Dom Jorge no início de seu bispado buscou focar suas ações pastorais junto ao sindicato de Santo André, Dom Cláudio buscou desenvolver trabalhos pastorais junto ao movimento sindical de São Bernardo do Campo e Diadema.

Os movimentos grevistas de São Bernardo do Campo marcam profundamente a identidade do catolicismo na ABC Paulista durante o final da década de 1970 e início da década de 1980, conforme observado por Ney de Souza: "Novos movimentos grevistas no período de 1978-1980 marcaram a identidade da diocese no início desta segunda fase de sua história": (Souza, 2015, p. 227-301).

Esse contexto de luta e de resistência do Novo Sindicalismo foi fundamental para marcar a atuação do episcopado de Dom Cláudio e a identidade do catolicismo não só no ABC Paulista, mas para todo o Brasil no que se refere ao processo de redemocratização. A defesa por uma nova ordem constitucional, anistia e a defesa das eleições diretas será o discurso de uma parte significativa da Igreja católica e de lideranças sindicais. "Os bispos enfatizaram reiteradamente que todo sistema político justo precisa efetivar a democracia, os direitos humanos e a participação": (Mainwaring, 2004, p. 176). 
Uma parte significativa da hierarquia episcopal, incluindo Dom Cláudio Hummes, integrantes da Pastoral Operária e lideranças sindicais tinham consciência política de que a transição para uma sociedade mais democrática e participativa não seria implementada dentro de um futuro próximo. Mas acreditavam que enquanto porta-vozes da Igreja e do movimento sindical brasileiro tinham o dever de denunciar a injustiça social e a solicitar uma nova ordem na construção da cidadania no que se refere à participação política.

Dom Cláudio teve uma atuação relevante junto à classe trabalhadora do ABC Paulista. O ano de 1977 pode ser considerado definitivamente como sendo o período das primeiras denuncias do bispo aos jornais que circulavam na região. Conforme uma matéria publicada em 11 de outubro de 1977, no Diário do Grande ABC: (Diário do Grande ABC, 1977) que traz uma denúncia do bispo sobre a injustiça social. Na Semana Estadual da Família, o bispo emite uma mensagem denunciando as estruturas injustas do capitalismo e das condições desumanas no mundo do trabalho como sendo os responsáveis pela desagregação da família brasileira, atingindo principalmente a classe trabalhadora.

À medida que a Diocese de Santo André sinalizava, por meio a ação episcopal de Dom Cláudio, uma tomada de posição no campo social e religioso junto ao movimento sindical do $\mathrm{ABC}$, encorajava não só padres, mas também o movimento de base como as CEB's (Comunidades Eclesiais de Base) e a própria Pastoral Operária. Quando a hierarquia clerical faz uma opção profética pelos operários esses movimentos católicos de base começam a organizar grupos de reflexões para discutir o cotidiano dos trabalhadores como suas relações sociais com os sindicatos e com os patrões. Para a Igreja os trabalhadores deveriam ser organizados dentro dos princípios norteadores da doutrina social que era criar nos operários uma solidariedade entre os trabalhadores e seus sindicatos.

\subsection{Organização da Pastoral Operária no ABC Paulista}

A partir de 1979, no $\mathrm{ABC}$, a luta política deixava o estreite reduto das esquerdas para ganhar expressão de massa no sindicalismo combativo. Nessa região, encontrava-se agora a caixa de ressonância política da conjuntara brasileira. Ao abordamos a organização da Pastoral Operária no ABC deveremos fazer a seguinte indagação se começou quando e como essa pastoral surge nessa região?

Não há uma data precisa de quando esse movimento se iniciou no $\mathrm{ABC}$, mas podemos mapear como a Pastoral Operária passou a se organizar como um movimento católico que atuaria na base da Igreja, construindo uma ponte entre a classe trabalhadora e a hierarquia 
clerical. Podemos considerar essa organização como sendo um processo que já ocorria no interior da Igreja Católica.

$\mathrm{Na}$ Igreja, esse processo foi sendo desenvolvido nas práticas pastorais de agentes pastorais e da hierarquia desde o surgimento da Ação Católica Geral, aprofundou-se com a Ação Católica Especializada e se completou com outras iniciativas da Igreja, a partir da sua Doutrina Social. Para Maria de Lourdes Tomio Stoin:

\footnotetext{
A Pastoral Operária possui uma ligação orgânica com a Igreja, participando de suas instâncias (encontros, assembleias), entretanto, possui vida própria, são os trabalhadores os responsáveis por suas decisões e condução, contando com a participação e apoio do clero: (Stoin, 2004, 201f).
}

A Pastoral Operária nasce no início da década de 1970, como um movimento constituído por trabalhadores católicos e também com a participação da hierarquia católica, mas se constitui como um movimento de interação com a classe operária a partir de 1978, principalmente, a partir das greves do ABC. É a partir da organização da Pastoral Operária que movimento sindical reencontra a possibilidade de se reorganizar, mobilizando a luta salarial e a legitimidade de greve. Apesar da Pastoral Operária ter como principal expoente o Sindicato dos Metalúrgicos do ABC Paulista, sua ação pastoral se expande para além das fábricas. Sendo assim, Stein explica que:

Em 27 de outubro de 1978, a Pastoral Operária lança seu primeiro documento de apoio às lutas operárias intitulado "Apoio aos trabalhadores do $\mathrm{ABC}$ ", no qual aponta a legitimidade da greve, afirmando que esta é e foi provocada pela intransigência dos patrões, pelo custo de vida e baixo salário: (Stoin, 2004, 201f).

Podemos observar na passagem acima explicitada por Stein, a Pastoral Operária acompanhou os acontecimentos e as situações da classe trabalhadora do ABC, engajando-se e solidarizando-se com os grevistas. A inflação saltava de $40 \%$ para mais de $70 \%$ ao ano. O Brasil experimentava a chamada "crise do milagre econômico". Diante desse cenário político e econômico, o regime militar procurava desenvolver uma política de dominação de classe, matando o controle sobre os movimentos católicos e sindicais que vinham crescendo rapidamente no $\mathrm{ABC}$ Paulista.

As greves que surgiram no ABC a partir do final da década 1970 e início da de 1980, espalharam-se para outros Estados. Desponta também as chamadas Comissões de Fábricas, fazendo oposições aos sindicatos atrelados aos patrões, exigindo aumento de salários e 
melhores condições de trabalho. Essa investida dos movimentos católicos e dos movimentos sindicais fez com lideranças de bases da Igreja e do movimento operária fossem presas.

Os militares atuaram no sentido de desconcentrar a mobilização dos operários e a intervir em vários sindicatos. Até meados da década de 70 acentuavam a desmobilização e a fragmentação do movimento operário e sindical, principalmente, à forte repressão do sistema político vigente. As investidas do aparato repressivo contra as mobilizações pareciam ter minado as últimas possibilidades de resistência da Pastoral Operária e do movimento sindical.

As possibilidades de organização e de capacidade de mobilização vinham do Novo Sindicalismo que surgia no Sindicato dos Metalúrgicos de São Bernardo do Campo, município no qual se encontrava boa parte das indústrias automobilísticas, e do apoio do bispo Dom Cláudio Hummes aos trabalhadores do ABC. Stein explica que:

No dia 30 de março de 1979, D. Cláudio Hummes lançava um nota de esclarecimento, na qual procurava tornar clara a presença da Igreja nas lutas operárias. $\mathrm{Na}$ carta, ele protesta contra a intervenção federal no sindicato dos metalúrgicos da região do $\mathrm{ABC}$ e contra as demissões nas fábricas: (Stoin, 2004, 201f).

Essa atuação pastoral de Dom Cláudio estava atrelada na própria formação pedagógica da Pastoral Operária e da Doutrina Social da Igreja. Além da hierarquia clerical do $\mathrm{ABC}$, a Pastoral Operária atuava junto ao movimento operário com outros movimentos católicos que também atuavam no campo da classe operária como a Juventude Católica Operária, Ação Católica Operária e os Círculos Operários. Sendo assim, desde 1979, a equipe executiva da Comissão de Pastoral Operária buscou criar um relacionamento com outros setores da Igreja.

O objetivo era a troca de experiência e contribuir para a construção de uma sociedade na qual os trabalhadores e os movimentos populares do campo e da cidade pudessem ter vez e voto. Isso englobava a atuação da Igreja em despertar no trabalhador a necessidade de levar o testemunho evangélico para o local de trabalho, ou seja, para o movimento operário.

Para Gilberto Carvalho, que foi metalúrgico e um dos fundadores da Pastoral Operária no Estado do Paraná, afirma que o terreno no qual a Pastoral Operária se sedimentou já havia sido preparado pelas Comunidades Eclesiais de Base. Assim, os trabalhadores das periferias dos centros urbanos passavam a se despertarem para uma nova perspectiva: "A necessidade de levar o testemunho evangélico para o local de trabalho, para o meio operário": (Carvalho, sem data). 
Desse modo, a Pastoral nascia como a perspectiva de ser um lugar no qual setores de base da Igreja passariam refletir sobre a atuação da militância operária, um estímulo para o desempenho evangélico no meio operário. Falando sobre a importância da experiência política da Pastoral Operária no mundo do trabalho Carvalho explica que:

\footnotetext{
Num contexto sindical absolutamente diverso (não tínhamos na época sequer um único sindicato que pudesse ser considerado combativo), o principal trabalho da PO era o de estimular a participação sindical de seus militantes e permitir uma formação sindical que os sindicatos sonegavam. (Carvalho, s. d.)
}

Nessa perspectiva a Pastoral Operária teve uma atuação decisiva na preparação greve dos metalúrgicos do $\mathrm{ABC}$ iniciada em 12 de maio de 1978, à medida que estimulou o Movimento Sindical a buscar uma qualificação dos militantes do ponto de vista bíblicoteológico, como um movimento sindical e político. Sendo assim, além de atuar na greve, os agentes da pastoral atuaram politicamente na formação de chapa de oposição ao sindicato atrelado ao Estado.

A ligação com a Pastoral Operária Nacional foi decisivo para que no $\mathrm{ABC}$ a pastoral encontrasse um caminho mais sólido junto aos operários. Durante alguns anos, a Pastoral Operária produziu um boletim mensal, com tiragem de aproximadamente 15 mil exemplares, intitulado "A Voz do Trabalhador". Esses exemplares serviram de importante meio de divulgação da mensagem e também como um espaço de denúncia do trabalhador.

A influência da Pastoral Operária no Movimento Sindical do ABC foi inteiramente relevante. A Pastoral Operária do $\mathrm{ABC}$ esteve presente em todos os eventos mais importantes do Movimento Sindical, através dos seus militantes, contribuindo, assim, para a consolidação de um Movimento Sindical forte e combativo em toda região do ABC Paulista. Aos poucos, as propostas de oposição sindical vão se tornando uma oposição aos dirigentes sindicais da época, e mais do que isso, passam a questionar a própria estrutura sindical existente que estava atrelada aos interesses do patronato.

Para Heloisa Helena Teixeira de Souza Martins, os integrantes da Pastoral Operária faziam oposição ao modelo burocratizado dos sindicatos porque o modelo de resistência operária não se deva por meio dos dirigentes sindicais, mas por meio da organização dos próprios trabalhadores. Assim explica a autora: "A predominância, ainda, era da ideia da organização dentro da fábrica, seja em grupos, seja em comissões, como forma de mobilizar os trabalhadores": (Martins, 1994. p. 23). 
Nos seus anos iniciais de organização a Pastoral Operária deu uma contribuição social e política para os operários à medida que aproximou a Igreja da classe trabalhadora. Por meio da Pastoral Operária, a Igreja se colocava próxima à classe operária como um meio de reafirmar sua presença em uma região essencialmente constituída por operários.

O operário se tonar um sujeito social inserido nos movimentos populares, buscando assim, reconhecer-se como agente coletivo da sua própria transformação social. Apesar de a Pastoral Operária apresentar o operário como sendo um sujeito coletivo, quando se pensa em classe, a Igreja e o movimento sindical não são portadores da unidade e universalidade. Sendo assim, a Igreja e o movimento sindical não agiam como sujeitos capazes de transformar sua própria libertação, mas como engrenagens de máquinas organizadoras.

Eder Sader faz uma análise interessante sobre as mudanças discursivas das instituições e dos movimentos sociais em crise no Brasil. Saber utiliza para sua análise, o recorte espacial e temporal a região da Grande São Paulo no período de 1970 a 1980. Para o autor, a Igreja tem que modificar o seu discurso teológico e sua prática após a investida de setores repressivos da ditadura militar contra membros do clero. A esquerda brasileira está enfraquecida por causa da derrota no enfretamento com a ditadura do pós-1964 e dos impasses internacionais na formulação de um discurso que supere a teoria marxista revolucionária. Além disso, o sindicato no ABC Paulista está passando por uma nova formulação discursiva e prática com o chamado Novo Sindicalismo.

O que Sader está chamando atenção é para a noção de sujeito coletivo. Isso porque essa noção de sujeito coletivo indicada por Sader passava por elaboração de uma nova identidade que se organizava por meio da prática dos membros da Igreja e do Novo Sindicalismo. Esses sujeitos coletivos passaram a defender os seus interesses e expressar as suas vontades, constituindo-se um novo sujeito (coletivo), lugares políticos novos (a experiência do cotidiano do homem simples) uma nova prática social (a busca por direitos, a partir da consciência de interesses e vontades dos próprios trabalhadores). Assim diz Sader:

\footnotetext{
A novidade eclodida em 1978 foi primeiramente enunciada sob a forma de imagens, narrativa e análise referindo-se a grupos populares os mais diversos que irrompiam na cena pública reivindicando seus direitos, a começar pelo primeiro, pelo direito de reivindicar direito. (Saber, 1988, p. 26).
}

A análise sociológica enfatizada por Sader dá uma contribuição interpretativa para essa pesquisa à medida que joga mais luz sobre o impacto dos movimentos sociais no $\mathrm{ABC}$ a partir de 1978. Isso possibilitou a uma revalorização das práticas sociais presentes no 
cotidiano popular como a criação de novos espaços políticos como os Clubes de Mães, Associações de Moradores, Comissões de Fábricas, Comunidades Eclesiais de Base e Pastoral Operária.

Nesses espaços públicos, as relações sociais passam a experimentar uma ampliação da fraternidade e da solidariedade. Esses espaços empenham-se na elaboração do espaço fabril como sendo o campo de solidariedade e de aprendizado da luta mais ampla, a consciência de classe no mundo do trabalho. Na linguagem pedagógica da Pastoral Operária abordava-se na conscientização da classe trabalhadora por meio da reflexão crítica da diretoria do sindicato para uma estrutura sindical. Tratando da oposição sobre a estrutura organizacional do sindicato Heloisa Helena Teixeira de Souza Martins explica que:

\begin{abstract}
Este trabalho da oposição sindical, que foi sempre uma luta miúda, subterrânea e constante, quando desenvolvido no barro, encontrava-se com as lutas desenvolvidas pelos movimentos populares. Era o trabalhador-passageiro de ônibus, o trabalhadormorador da periferia, o trabalhador-consumidor de bens e serviços públicos que, com base em problemas concretos vividos cotidianamente, se organizava e lutava para resolvê-los. (Martins, 1994. p. 23-24).
\end{abstract}

A vida social do homem simples da classe trabalhadora é atravessada por mecanismos de dominação e de exploração. O cotidiano do trabalhador das fábricas do $\mathrm{ABC}$ Paulista se dá dentro de um contexto de luta não só para viver a vida de todo dia, mas para transformar a sua própria realidade social. O padre Agostinho Pretto, uma das principais lideranças religiosas que integravam a Comissão Nacional da Pastoral Operária, afirmou que:

\begin{abstract}
A classe operária, enquanto se articula, organiza e constrói o seu próprio projeto, a partir do qual nos convida a conhecer sua história e nunca perder de vista suas organizações e suas conquistas. A Igreja, enquanto sinal de Jesus Cristo, que desafia os cristãos para o compromisso com os trabalhadores, os oprimidos e os mais pobres. (Pretto, sem data).
\end{abstract}

Historicamente, no ABC Paulista, a Pastoral Operária se consagra com base em suas duas vertentes: a classe operária e Igreja. O propósito dos integrantes da Pastoral Operária para a classe operária era construir uma sociedade justa e igualitária. Já para a Igreja, o propósito era construir uma Igreja horizontal em vez de vertical, ou seja, uma Igreja fiel ao Evangelho de Jesus de Nazaré, que desejava estar presente nas lutas dos trabalhadores. 


\section{Considerações finais}

Quando olhamos para o surgimento da Pastoral Operária, nós devemos lavar em considerações as necessidades dos "novos tempos". Esses "novos tempos" respondem uma "nova necessidade de ser Igreja", ou seja, a necessidade de uma Igreja renovada pelo Concílio Vaticano II e pela Segunda Conferência dos Bispos da América Latina, realizada em Medellín, em 1968 e Terceira Conferência dos Bispos Latino-Americanos em Puebla em 1979. Esses acontecimentos contribuíram para o fortalecimento de uma participação popular dentro da Igreja por meio dos serviços pastorais.

É dentro dessa perspectiva de renovação da Igreja e do fortalecimento dos serviços pastorais é que se deu a participação da Pastoral Operária nas greves do $\mathrm{ABC}$, bem como a Primeira Conferência Nacional da Classe Trabalhadora a (CONCLAT) em agosto de 19981, na Praia Grande no litoral paulista. Dessa conferência surgiu o movimento nacional PróCentral Única dos Trabalhadores, contribuindo assim para a fundação da Central Única dos Trabalhadores em 28 de agosto de 1983.

Sendo assim, a Pastoral Operária teve sua fonte enraizada na combatividade da luta da classe trabalhadora e ao mesmo tempo inserida na vida eclesial. Essa inserção dos cristões católicos no movimento sindical e deste na Igreja significava marcar a presença da Igreja no mundo do trabalho e a presença no mundo no trabalho na Igreja.

A Pastoral Operária do ABC Paulista tinha como premissa sensibilizar o conjunto da classe trabalhadora para os valores evangélicos e empenhando para que o conjunto da Igreja se tornasse sensível à opção pelos pequeninos, pelos pobres e pelos trabalhadores.

\section{Referências Bibliográficas}

\section{Livros}

MAINWARING, Scott. A Igreja Católica e a política no Brasil (1916-1985). São Paulo: Brasiliense, 2004.

MARTINS, Heloisa Helena Teixeira de Souza. Igreja e movimento operário no ABC: 1954-1975. São Paulo: Hucitec; São Caetano do Sul: Prefeitura de São Caetano do Sul, 1994.

SABER, Eder. Quando novos personagens entraram em cena: experiências, falas e lutas dos trabalhadores da Grande São Paulo, 1970-80. Rio de Janeiro: Paz e Terra, 1988.

Trabalho de Conclusão de Curso, Dissertações e Tese

STEIN, Maria de Lourdes Tomio. A experiência do Trabalho: as práticas da Pastoral Operária em Curitiba (1965-1999). 2004. 201f. Tese. (Doutorado em História). Programa 
Pós-Graduação em História - Linha de Pesquisa Cultura e Poder. Setor de Ciências Humanas, Letras e Artes. Universidade Federal do Paraná. 2004.

Revistas

SOUZA, Ney de. O bispo e as greves do operariado no ABC, disputas e tensões entre a Igreja Católica e a ditadura militar. In: A Revista História e Cultura. Franca, v. 4, n. 2, p. 277-301, set. 2015.

Artigos científicos

BRITO, Ricardo José Braga Amaral de. O Novo Sindicalismo Brasileiro e o papel da crítica: Análise das estratégias de engrandecimento da prática sindical brasileira na década de 1980. Primeiros Estudos, São Paulo, n. 6, p. 87 - 101, 2014.

CEDIC PUC-SP (Centro de Documentação e Informação Científica

A política do grande capital: Encontro realizado no dia 6 de dezembro de 1980, no Centro de Formação de Líderes da Diocese de Nova Iguaçu, entre agentes pastorais e sindicalistas para debater as experiências da Pastoral Operária de São Bernardo do Campo.

CARVALHO, Gilberto. Depoimento Gilberto Carvalho em comemoração aos 10 anos da Pastoral Operária. Documento sem data.

Dom Cláudio denuncia a injustiça social. Diário do Grande ABC, 11 de outubro de 1977.

PRETTO, Pe. Agostinho. Secretariado Nacional da Pastoral Operário. Mariano Sendra dos Santos, 44 - Sala 501, Duque de Caxias, RJ.

Política econômica do ponto de vista dos trabalhadores. Encontro realizado no dia 6 de dezembro de 1980, no Centro de Formação de Líderes da Diocese de Nova Iguaçu, entre agentes pastorais e sindicalistas para debater as experiências da Pastoral Operária de São Bernardo do Campo. 


\title{
O Cemitério do Peixe e as Missões Redentoristas
}

\author{
The Cemitério do Peixe and Redemptorist Missions
}

\author{
Thiago Rodrigues Tavares ${ }^{44}$ \\ thiagor.tavares@yahoo.com.br
}

Resumo: Registros apontam que pelo menos desde meados do século XIX, ocorre no Cemitério do Peixe, na Serra do Espinhaço, região centro-norte de Minas Gerais, uma Festa em devoção às almas daquele lugar. A devoção às almas apresenta características próprias do catolicismo popular, fruto da porosidade da vivência religiosa no Brasil. No entanto, ao final do século XIX e início do século XX, temos um período marcado pelo início da República e pelo processo de romanização do catolicismo. Nesse momento, chegaram ao Brasil os Padres Redentoristas holandeses, os quais pregaram missões por toda Minas Gerais. Diante disso, a partir da análise de documentos, pretende-se abordar a atuação dos padres Redentoristas holandeses no Cemitério do Peixe, entre os anos de 1933 e 1940.

Palavras-chave: Cemitério do Peixe, Redentoristas, Festa, Catolicismo Popular

Abastract: A religious festival in devotion to the souls placed at the Cemitério do Peixe in the Serra do Espinhaço northern-central region of Minas Gerais is documented at least since the mid-nineteenth century. Due to the porosity of religious experience in Brazil, the typical characteristics of popular Catholicism are displayed through the devotion to the souls. Nonetheless, in the late nineteenth and early twentieth centuries we had a period marked by the Republic's beginning and the Catholicism's romanization process. In that moment, redemptorists arrived in Brazil preaching missions throughout Minas Gerais. Therefrom, based on the records analysis, this paper intendeds to approach the dutch redemptorists actions at the Cemitério do Peixe in the period of 1933 and 1940.

Keywords: Cemitério do Peixe, Redemptorists, Religious Festival, Popular Catholicism

\section{Introdução}

Registros apontam que, pelo menos desde meados do século XIX, ocorre no Cemitério do Peixe, na Serra do Espinhaço, região centro-norte de Minas Gerais, uma Festa em devoção às Almas daquele lugar. Atualmente leva o nome de "Jubileu de São Miguel e Almas". O lugar destaca-se por nunca ter sido habitado constantemente, permanecendo vazio durante a maior parte do ano. Porém, em torno do dia 15 de agosto, o local recebe milhares de pessoas. O registro mais antigo encontrado até o momento reporta sobre a realização da Festa no ano de 1861, porém, acredita-se que a origem da Festa seja mais pretérita, ligada ao período da Demarcação Diamantina. A devoção às almas apresenta características próprias do

\footnotetext{
${ }^{44}$ Doutorando em História pela Universidade Federal de Juiz de Fora. Bolsista FAPEMIG
} 
catolicismo popular, fruto da porosidade da vivência religiosa no Brasil. Ocorre que, no final do século XIX, temos um período marcado pelo início da República além do processo de romanização do catolicismo. Nesse mesmo momento, chegaram ao Brasil os padres redentoristas holandeses, que pregaram missões por toda Minas Gerais. Desse modo, a partir da análise de documentos, pretende-se abordar sobre a atuação dos padres redentoritas holandeses no Jublieu de São Miguel e Almas, no Cemitério do Peixe, entre os anos de 1933 e 1940. Foram levantados dados e informações que nos contam sobre a história do encontro, no Cemitério do Peixe, entre os missionário e a população do centro-norte de Minas Gerais, pessoas do meio rural, habitantes da Serra do Espinhaço e devotas das Almas do Peixe. A região, composta na época por um pequeno grupo de uma elite rural, além de uma massa empobrecida formada por remanescentes da escravidão, quilombolas, garimpeiros, tropeiros, empregados de fazendas, agricultores etc.

Diante disso, observa-se que no lugar denominado Cemitério do Peixe havia uma vivência religiosa popular. O Brasil daquele período era marcado pelo culto aos Santos, pela falta de clérigos e pela forte atuação religiosa dos leigos. O catolicismo brasileiro estava muitas vezes limitado à concepção pré-tridentina trazida pelos portugueses, relegado a práticas e expressões devocionais que, aparentemente, limitava-se a "exterioridades", um catolicismo leigo e social (NETO, 2006). Segundo Azzi (1997), no Brasil, o catolicismo apresentou duas formas distintas. A primeira, o catolicismo da elite portuguesa, detentora do poder monetário e político na colônia, conhecido como catolicismo patriarcal, marcado pela ligação de bispos e padres com a coroa portuguesa, em outras palavras, pela relação de troca entre a Igreja Católica e o Estado - regime de padroado. A segunda forma de catolicismo, conhecida por catolicismo popular tradicional, chegou ao país através dos portugueses pobres, estabelecida principalmente nas zonas rurais. Ficou marcada pela sua porosidade devido à relação entre os colonos pobres, os índios destribalizados, os ex-escravos e todos os tipos de mestiços.

A chegada dos Padres Redentoristas ocorreu no período de intensificação do processo de romanização no Brasil, tal reforma católica visava implantar um mesmo modelo de catolicismo para todos, definido pela centralização da religião em torno de Roma. Além da erradicação de catolicismos locais considerados supersticiosos e fanáticos. No Brasil, esse processo ganhou fôlego no final do século XIX, com a Proclamação da República e separação entre Igreja e Estado. Nesse momento temos a marca da ação dos bispos reformadores, que haviam traçado um plano concreto de entregar as ordens religiosas europeias à alguns centros de devoção no Brasil. Dentre os motivos para essa ação, estava o fato de aproveitar os centros 
de grande aglomeração popular para uma autêntica catequese do povo, ao mesmo tempo suprimir as manifestações de superstição e fanatismo existentes. Além de poder exercer maior controle financeiro sobre as doações. O movimento dos bispos renovadores, além de criticar e buscar reformar o catolicismo de tradição colonial procurou também dar uma nova orientação ao catolicismo do povo brasileiro, por meio de novas formas de devoção e de piedade, com uma orientação centrada na vida sacramental. Desse modo, além do catecismo, destinado ao ensino religioso do povo, os bispos procuraram através do auxílio das ordens religiosas, difundir o novo espírito religioso através das missões populares ou sagradas missões - como as que ocorreram no Cemitério do Peixe - a finalidade primordial da missão é a conversão do povo à vida sacramental: casamentos, confissões e comunhões (AZZI, 1977).

Assim, o catolicismo popular tradicional, passou por uma série de transformações provocadas por mudanças internas na Igreja Católica e por mudanças na sociedade brasileira. Contudo, muitas características do culto popular permaneceram. Para Azzi (1977), em alguns lugares o povo assimilou da tal forma alguns elementos do catolicismo romano e os conciliou ao catolicismo tradicional, que passaram a constituir assim uma nova estrutura da tradição religiosa popular. Perceberemos que a Festa para às Almas no Cemitério do Peixe era um exemplo do tipo de festividade que, na opinião do episcopado, deveria sofrer o controle da Igreja e a purificação do ritual. Com frequência, os bispos denunciavam os jogos, as danças, as diversões e o próprio comércio que ocorria por ocasião das festas religiosas. A grande preocupação dos bispos orientava-se no sentido de afastar das festas religiosas tudo o que tinha ar de profano, reduzindo-se a uma dimensão puramente sagrada. Desse modo deveriam ser combatidas as exterioridades religiosas (AZZI, 1977).

Os padres redentorsitas chegaram ao Brasil com o objetivo de realizar as Santas Missões e de levar os sacramentos, além da palavra de Deus para a população mais necessitada. Além de terem atuado no Brasil no período de maior efervescência do processo de romanização e da influência dos Bispos Reformadores. Os redentoristas não transformaram por completo o catolicismo que já estava estabilizado no Brasil. A religiosidade no país era considerada pelos missionários pouco "esclarecida", se vista de conformidade com a ortodoxia europeia da época (NETO, 2006). Portanto, veremos a partir do exemplo do Cemitério do Peixe, que esses missionários trocaram experiências e vivências com a população, afetando e sendo afetados, agenciando e sendo agenciados. 


\section{A origem do cemitério do peixe}

A origem do Cemitério do Peixe é marcada por mitos e histórias. Entre as pessoas que frequentam o lugar desde a sua infância, ou como eles mesmos preferem dizer, "desde a barriga da mãe", circulam histórias intrigantes, as quais remontam ao período colonial, quando aquela região estava no centro das atenções de Portugal. O Cemitério teria surgido no período da intensa exploração de diamantes, que ocorreu ao longo dos séculos XVIII e XIX, em Minas Gerais. O lugar estava nas imediações do Distrito Diamantino, uma ordem administrativa e territorial, especialmente criada pela Coroa Portuguesa, originalmente demarcada em 1734, sendo ampliada em 1739, 1753 e 1757, com o intuito de controlar a exploração de diamantes (CARRARA, 2017).

Nos mitos narrados pelos frequentadores sobre o surgimento do lugar, destacam-se três personagens principais: os soldados, os escravos e os peixes. Um dos mitos conta que, naquele lugar, existiu um quartel com o objetivo de impedir o contrabando de diamantes. Os soldados que ali estavam, muitas vezes, alimentavam-se de peixes pescados no Rio Paraúna. Porém, em um determinado momento, esses soldados consumiram peixes estragados, vindo a morrer. Como é um local isolado, esses soldados foram enterrados por ali mesmo, culminando no Cemitério. Outro mito conta a história de um escravo, cujo nome era Peixe, o qual foi encontrado morto naquele lugar, sendo enterrado por ali mesmo, dando origem ao Cemitério. Esses mitos desencadeiam diversas histórias. Os únicos que aparecem em todas as versões são os peixes - seja no alimento ou no nome.

As estradas que circundam as imediações do Vilarejo do Cemitério do Peixe foram rotas de diversas pessoas durante o período colonial: fazendeiros, garimpeiros, tropeiros, indígenas, escravizados e quilombolas passaram por ali. Observa-se que o lugar não foi habitado, entretanto, seu terreno estava próximo aos quartéis de fiscalização da Coroa Portuguesa, cercado por fazendas escravocratas e por indivíduos garimpando nas águas do Rio Paraúna. Evidencia-se que, durante esse período, as pessoas ainda não tinham local adequado para serem enterradas, principalmente, os escravizados e os mais pobres. Nesse processo, o lugar passou a receber os mortos da região, formando o Cemitério do Peixe. Nesse contexto às Almas do Peixe começaram a ser cultuadas e assim passou a ocorrer a Festa.

Até o momento, o registro mais antigo encontrado, foi uma notícia publicada na edição 40, do jornal O Jequitinhonha, de Diamantina, na seção Publicações à Pedido, do dia 16/11/1861. Nesta publicação, é possível perceber que o local reúne muitas pessoas em busca de oração, comércio, festa, jogos, bebidas e divertimento. 


\begin{abstract}
Antes de narrar o que observei no dia 15 de agosto de 1861, no lugar denominado Cemitério do Peixe, - é mistério da origem da devoção que nesse dia ahi se faz; $\mathrm{O}$ Reverendo Camilo de Lellis Vianna, Parocho encomendado da Freguezia de Goveia, de feliz memória, devido do seu zelo religioso, alcançou do Exmo. e Revmo. Senhor Bispo Mariannense a concessão de celebrar-se o Santo Sacrifício n'uma pequena Ermida, junto ao cemitério já citado, e alem da Missa, tem os fieis de mais ou menos 40 dias de indulgencias; mas como poder-se-há lucra tão grande benefício, erguendo-se barracas ou botequins, onde se achão todas as qualidades de bebidas, cujos avidos vendedores, nada mais ambicionão, do que sues interesses lurativos? $\mathrm{Na}$ vespera do dia 15 de Agosto diferentes negociantes vão para esse lugar, é entorno do cercado do cemitério, em torno mesmo da Ermida elevão seus cazebres momentaneos, tornando assim, esse dia 15 uma verdadeira feira, ou melhor, um bachanal pela profusão de licores, ahi se bebe ao ponto de reunidas contendas, como já as tem havido, que chegão a ferirem-se uns aos outros, poucas são as pessoas que dotadas de um espírito verdadeiramente religiozo, meditão nesse quadro cercado e defendido pelo Estandarte da Religião ahi arvorado, onde habitão para sempre esses corpos outr'ora vivificados; talvez, de mil a mil e tantas pessoas, que nesse dia ahi se ajuntão só a $3^{\mathrm{a}}$ parte irá cumprir o preceito da Missa e dar de coração a essas almas um $<<$ REQUIESCANT IN PACE $>>$ Eis o que se passa na tarde do dia 15 parte e do dia 16 de Agosto de todos os annos. O respeito devido aos mortos é ahi interrompido, porque mesmo dentro do cercado girão taboleiros de sequillos, garrafas pejadas de differentes bebidas, ditos não próprios do lugar e só próprios da mais furioza bachanal Exmo. e Revmo. Prelado, suspendesse por sua reconhecida ciência e virtudes, essa concessão tranferindo-a desse campo a alguma Matriz ou capella onde o seu parocho ou capellão aplicasse as indulgencias aos Fieis a favor dessas almas? Só assim poder-se-hia evitar funestas consequencias para o futuro $<<Q U O D$ DEES ABSER>>." (O callado observador, 1861: p. 4).
\end{abstract}

O Callado Observador, pseudônimo utilizado por quem escreveu o artigo, aparentemente de calado não tem nada. Observa-se que escreve com um pensamento típico de sua época, fomentado muitas vezes por uma ação romanizadora. $\mathrm{O}$ autor destaca que, na véspera do dia 15 de Agosto, diferentes negociantes encontram-se no entorno do cemitério e da Ermida, onde montam seus cazebres momentaneos, tornando, assim, o dia 15 uma verdadeira feira, ou melhor, um "bachanal pela profusão de licores, ahi se bebe ao ponto de reunidas contendas", poucas são as pessoas dotadas de um espírito verdadeiramente religioso. O autor do artigo, por fim, recomenda a retirada da concessão da Festa, que deveria ser transferida do campo para alguma Matriz. Fato que não ocorreu. A crítica do autor está direcionada à ação religiosa popular, que mistura o sagrado e o profano, característica típica das Festas religiosas do período colonial.

O que o Callado Observador aparentemente não percebeu, foi que os frequentadores não precisavam da Igreja Católica para a realização da Festa. Aquela Festa provavelmente já ocorria naquele lugar há um bom tempo. Organizada por leigos e reunindo a população afrobrasileira que vivia naquela região de Minas Gerais, naquele ponto da Serra do Espinhaço. A situação apresentada acima nos leva a constatar que, naquele ano de 1861, o Cemitério do Peixe já estava nos radares da ação dos bispos reformadores, os quais buscavam controlar as 
festas, os lugares de peregrinação, o catolicismo popular, dentre outras coisas. No ano citado, a missa ficou por conta de padre Camilo Lellis Vianna, pároco de Gouveia que atende ao pedido do bispo de Mariana, Antônio José Ferreira Viçoso.

O local de sepultamentos, formado no período colonial e sacralizado pela população local, adquire novos contornos nas primeiras décadas do século XX, quando a organização e controle do espaço ficam por conta de Antônio Francisco Pinto, conhecido por Canequinha (05/06/1860 - 08/07/1941). Segundo relatos, Canequinha construiu a Igreja de São Miguel, a casa paroquial e a casa dos romeiros. Chaves (2016), estudioso da região e sobrinho-neto de Canequinha, aponta que a Igreja de São Miguel foi construída entre os anos de 1915 e 1916, por dois irmãos gêmeos: Francisco José Pinto e José Francisco Pinto. Segundo o pesquisador, os irmãos eram "profissionais respeitados, carpinteiros e pedreiros". Depois de erguer as construções, Canequinha conseguiu colocar o Cemitério do Peixe na rota das missões redentoristas. Os padres redentoristas chegaram à região, mais precisamente em Curvelo, no ano de 1906, e, desde então, realizavam as missões por toda a região centro-norte de Minas Gerais. O objetivo era levar a palavra de Deus e os demais sacramentos - batismo, confissão, unção, eucaristia e casamento - para a população isolada no sertão mineiro. Como já vimos, as pessoas já frequentavam o Cemitério do Peixe para festejar, ter relações amorosas, jogar, rezar pelas almas, comercializar, trocar e socializar. Os padres redentoristas durante pelo menos 30 anos garantiram os sacramentos da Igreja Católica para a população que já frequentava o Cemitério do Peixe. Foi nesse momento, entre os anos de 1915 e 1916, que a festa das almas tornou-se Jubileu de São Miguel e Almas. Apesar da devoção ao São Miguel Arcanjo, a fé das pessoas sempre esteve ligada às Almas do Peixe, tanto que, Canequinha, em 1940, um ano antes da sua morte, doou em cartório todo o terreno do Cemitério para as Almas do Peixe: Segundo consta no Registro de imóveis, livro 3-G de transcrição das transmissões, folhas 153verso/154, registro n²573 de 28/05/1940. “Adquirente: As Almas do Cemitério do Peixe, no distrito de Costa Sena. Transmitentes: Antônio Francisco Pinto e sua mulher D. Rosaura Dummont Pinto".

Para o homem do interior, que vive isolado em sua pequena comunidade rural ou na pequena cidade, a experiência da grande festa do santo, com a afluência de uma massa de devotos é, certamente, uma experiência marcante. Uma romaria que culmina com a festa do santo de devoção é certamente inesquecível! (OLIVEIRA, 1988, p. 117).

Durante o Jubileu de São Miguel e Almas, as pessoas se mudam para o Cemitério do Peixe. Ainda que o espaço disponha de pouca estrutura, muitas pessoas participam durante 
todos os dias de festa. Para dormir, muitos dos frequentadores permaneciam acampados em barracas de pano, como faziam os tropeiros, outras de capim, ramos, varas de bambú. A cangalha servia de této e a capa de porta. Além de casas de sapé, os frequentadores passaram a construir também casas de adobe, técnica construtiva de uma arquitetura vernácula baseada na moldagem manual do elemento natural. A terra retirada do próprio terreno é misturada com a água e capim, e a mão do adobeiro determina a forma do tijolo. Antes da construção da estrada, muitos seguiam para o Peixe a pé ou montados em cavalos ou mulas, passando por trilhas e cruzando rios. Em seguida, com a abertura da estrada de terra, tornou-se possível usar o carro de boi, posteriormente o automóvel. Até os dias de hoje, as pessoas precisam levar o necessário para a sua subsistência, como comida e utensílios de cozinha. A água para cozinhar, tomar banho, lavar roupas e vasilhas vinha do Paraúna. A mata ao redor do Peixe era utilizada como banheiro. A iluminação era fornecida por candeias, tochas, lamparinas e fogueiras.

Durante o Jubileu, as pessoas vivenciam um grande e forte momento de sociabilidade. Diferentes comunidades do meio rural e de cidades da região tem a possibilidade de festejar, se divertir e estabelecer relações sociais com trocas de afetos e trocas econômicas. Muitos são os casos de famílias que se formaram a partir da festa do Peixe. O Peixe é uma possibilidade dos jovens se relacionarem. Diversas pessoas da região contam que diferentes gerações das suas famílias foram formadas a partir de relacionamentos ocorridos durante o Jubileu de São Miguel e Almas. Avós, filhos, netos e bisnetos que se casaram depois do namoro no Cemitério do Peixe.

Assim, além de buscarem relações amorosas e diversão, os frequentadores do Cemitério do Peixe também procuram o comércio que ocorre no lugar. Jogos e bebidas eram práticas comuns, além da venda de produtos para casa, como: panelas, vasilhas, roupas de cama e vestimentas pessoais. O comércio de animais era intenso, mulas e cavalos eram comercializados e, nesse comércio, uma característica é lembrada ainda nos dias de hoje, em que era comum as pessoas comprarem um animal para pagar um ano depois, no Jubileu do ano seguinte. O pagamento ocorria, muitas vezes, com a troca por outros animais ou com o resultado da colheita. Desse modo, diversas pessoas se lembram dessas vendas destacando a confiança e lealdade que existiam no passado.

O comércio, namoro e diversão faziam parte da Festa, mas eram também acompanhados pela parte religiosa. Sabemos que no ano de 1861, o Padre Camilo de Lellis Vianna da Paróquia de Gouveia, foi o responsável pelas celebrações no Peixe. Segundo relatos de frequentadores do Jubileu, desde 1915 foram os padres redentoristas holandeses que 
garantiam a salvação das almas daquele lugar. Era comum a presença de quatro, cinco e até seis mil pessoas durante o Jubileu, o que contabilizava milhares de confissões e comunhões, além de muitos casamentos e batismos. As missões redentoristas tinham como objetivo levar a palavra de Deus e os sacramentos da Igreja até aquelas pessoas mais isoladas. Como veremos a seguir, os padres redentoristas tiveram êxito em sua empreitada.

\section{As Missões Redentoristas}

A Congregação do Santíssimo Redentor, comumente chamada de Congregação Redentorista, foi fundada por Santo Afonso Maria de Ligório, em 09 de novembro de 1732, em Scala, sul da Itália, sendo provada em 25 de fevereiro de 1749, pelo papa Bento XIV. Seguindo o lema: Copiosa Apud Eum Redemptio - o qual significa: "Com ele há Copiosa Redenção”, a congregação foi fundada para dedicar suas funções à evangelização dos mais pobres, através das missões.

Algumas situações concomitaram para a chegada dos padres redentoristas no interior de Minas Gerais. Dentre elas, as transformações estruturais na Igreja Católica e no Brasil. O período é marcado pela abolição da escravidão e o início da República no Brasil. No que tange a Igreja Católica, contata-se que ainda havia falta de clérigos em Minas Gerais e no Brasil como um todo, com a forte presença das irmandades e a atuação de leigos ministrando as ações religiosas. Contudo, nesse momento ocorreu um processo de reorganização da estrutura da Igreja Católica através da romanização. Esse processo teve como objetivo uma ação renovadora de congregações, bispos e padres, a partir de uma visão eurocêntrica e homogeneizante, baseada em um modelo romano de religião, com destaque para a prática dos sacramentos e a hierarquia eclesiástica. A Igreja almejava suprimir da religiosidade do catolicismo considerado popular o que consideravam superstição e fanatismo. (CAMURÇA, 2004). A chegada de congregações estrangeiras estava relacionada a atuação de bispos reformadores. No que tange a chegada dos padres redentoristas Holandeses deve-se destaque a atuação de Dom Silvério Gomes Pimenta. Primeiro arcebispo negro do Brasil e primeiro membro do clero brasileiro eleito imortal da Academia Brasileira de Letras.

Após diversos pedidos realizados por Dom Silvério, então arcebispo de Mariana, chegaram ao Brasil, os primeiros padres redentoristas. De nacionalidade holandesa, os Padres Mathias Tulkens e Francisco Lohmeyer, desembarcaram no Rio de Janeiro em 02 de julho de 1893. Foram logo em seguida para Mariana, onde foram recebidos por Dom Silvério. Depois do período de adaptação em Mariana e após conhecerem as possibilidades de trabalho no 
Brasil, estabeleceram-se em 1894 na cidade de Juiz de Fora. Em 26 de abril de 1894, chegaram outros redentoristas holandeses, três padres e três irmãos leigos. Nos anos seguintes mais padres foram enviados da Holanda para o Brasil. Até que em Janeiro de 1900, se estabeleceu em Belo Horizonte a segunda casa redentorista (NETO, 2006).

Em 1904, os referidos padres realizaram missões na região central e norte de Minas Gerais e, dois anos depois, em 1906, fixaram casa na cidade de Curvelo, com objetivo de atender ao norte de Minas Gerais. A ida para Curvelo ocorreu por insistência do então bispo de Diamantina, Dom Joaquim Silvério de Souza. O vigário de Curvelo à época, Padre Cônego Francisco Xavier de Almeida Rolim, que era também presidente da Câmara de Curvelo e Deputado Estadual, foi quem acertou os detalhes da fundação do convento redentorista na cidade (ARAÚJO, 1988).

Foi no dia 18 de setembro de 1906, pelas 11:30h da manhã, pelo expresso da "Central do Brasil"(...) chegariam os Padres Redentoristas holandeses para, aqui, fundarem um Convento, Curvelo, cidadizinha do inetrior (com 4.000 habitantes) estava em peso na Estação Central(...) Foguetes, bombas, grande alvoroço e alegria. O trem parou e de dentro saíram dois padres e um irmão leigo. Seus nomes: Pe Tiago Boomaars, Pe José Goossens e Irmão Filipe Winter. (ARAÚJO, 1988, P.58).

De acordo com Araújo (1988), desde 1906, os Padres trabalharam na cidade e nas capelas rurais da paróquia. Realizaram missões populares, dentro e fora da Arquidiocese de Diamantina. Talvez nesse período já tivessem atuado ou ouvido falar no Cemitério do Peixe, porém, segundo a história contatada pelos frequentadores do Peixe, os redentoristas teriam chegado ao Vilarejo apenas com a fundação do Jubieu, entre os anos de 1915 e 1916. Vários jornais da região noticiaram a participação dos padres redentoristas no Cemitério do Peixe, sobretudo, a partir do ano de 1933. Os anos de 1910 e 1940 são considerados os "anos de ouro" da atuação dos redentoristas no Brasil.

Jornais como o Pão de Santo Antônio e A Estrella Polar, registaram entre os anos de 1933 e 1940, a participação de pelo menos oito padres redentoristas na realização do Jubileu. Os padres que viviam em Curvelo circulavam por toda a região centro-norte de Minas Gerais. Por onde passavam, arrastavam e reuniam multidões. Ao longo da pesquisa, tivemos a oportunidade de ler artigos de jornais, além de consultar as próprias fotografias da época, guardadas nos albúns da Congregação Redentoristas. Jornais e fotografias mostram como as pessoas aproveitavam a oportunidade das missões para poder confessar, batizar, comungar, casar, etc. 
Uma característica singular das missões redentoristas é o fato de que a sua principal função era a conversão do povo à vida sacramental e o abadono de práticas populares. Contudo, em Minas Gerais, surpreendem devido ao caráter "exterior" de suas pregações. "Observa-se uma reprodução em escala considerável, de manifestações de "exterioridade", em festas de santos, procissões, romarias etc." (CAMURÇA, 2004, p.227). Assim, as missões caracterizavam-se como um momento de festa. Apesar de, inicialmente, a vivência religiosa popular ter assustado os padres redentoristas, acostumados com outro catolicismo, logo eles foram tocados por essa vivência própria de religiosidade praticada pela população local. Por isso, durante as missões redentoristas em Minas Gerais, ocorriam fogos de artifício, cavalgadas, bebidas, comidas e divertimento. Desse modo, apesar dos preconceitos característicos da época, os redentoristas aproximaram-se do povo. Agenciando e sendo agenciados por essa população.

Dentre as notícias encontradas, as mais antigas foram publicadas pelo jornal Pão de Santo Antônio, nos anos de 1933, 1934 e 1935. Todas receberam o mesmo título "Cemitério do Peixe". A primeira notícia encontra-se na edição 47, publicada em 27 de agosto de 1933, na página 3. Com o título "Cemitério do Peixe", o texto informa que se realizaram na localidade citada, as Santas Missões anuais, que foram pregadas pelos padres redentoristas Tiago e Frederico. De acordo com a notícia "foi enorme a concorrência do povo, que soube comportar-se, com ordem e respeito, como sempre". Segundo o Jornal, foram realizadas: 2068 confissões; 3558 comunhões e 2 casamentos legitimados.

A segunda notícia, do dia 30 de setembro de 1934, edição 52, página 4, informa que "Realizaram-se na localidade, distrito de Paraúna, município de Conceição, entre os dias 10 a 15 de Agosto, as Santas Missões”, pregadas "pelos abnegados sacerdotes Revmos. Padre Tiago, André e Frederico, Redentoristas", relatando novamente que tudo correu com muita ordem e respeito, com destaque para a "enorme concorrência". O resultado das Missões: Confissões 2317, Communhões 3900, Crismas 460, Casamentos 16 e Batisados 25.

Já no ano de 1935, publicado na edição 49, página 3, de 01 de setembro, diz o texto que se realizou as Santas Missões entre os dias de 10 a 15 de Agosto. Pregadas pelos Missionarios Redentoristas, Padre Tiago, Godofredo e Mathias. A notícia prossegue, dizendo que foi enorme a concorrência de fieis, reinando bôa ordem e o devido respeito, não obstante a grande aglomeração do povo e a falta de recursos para hospedagem. Nesse ano ocorre um total de 2458 Confissões, 4400 comunhões, 22 casamentos e 20 batisados.

O Jornal A Estrella Polar também informa sobre a realização da Festa e da participação dos padres redentoristas no ano de 1935: 
Tão singular como o seu nome, é o arraial de Cemiterio do Peixe. Dista 5 legoas alem de Gouvêa. Differe de todos os outros logares, pelo facto curioso de ter vida e movimento, sómente em 4 ou 5 dia durante o anno. É de 10 a 15 de Agosto, por occasião do Jubileu annual das almas. Nesses dias, Cemiterio do Peixe desperta e vive. Abrem-se todas as casas em numero talvez de cem. Branqueiam centenas de barraquinhas, pelos campos. Seis mil pessôas advindas das redondezas, e até de muito longe, emprestam-lhe movimento e animação. $\mathrm{O}$ sino da capella tange alviçareiro; e, a voz dos missionarios propaga a palavra de Deus. Quem passa alli por aquelles dias, leva a melhor das impressões. Mas, são só quatro dias cheios. Passados os quaes, apagam-se os fógos, desarmam-se as barracas; e, apóz um exodo completo daquelles improvisados habitantes, entra o arraial na costumeira quietude. E uma grande saudade paira naquellas cercanias. Dir-se-ia um logar encantado como aquellas cidades submarinas de que falam as Mil e Uma Noites, com a differença que a vida de Cemiterio do Peixe se manifesta em 4 dias só, e dentro de um grande mar, no meio de um immenso oceano: das graças e bençams de Deus. Pregaram alli este anno, o jubileu, os Rvmos. Redemptoristas, Snrs. Pe. Thiago Boomars, Pe. Godofredo Stribos e Pe. Mathias Moonen. Houve 2458 confissões, 4400 communhões, 22 casamentos e 20 baptisados. Apesar do intenso movimento de pessôas, provindas de todos os lados, não se registrou alli nenhum incidente desagradavel, tendo havido muita ordem e respeito. É o que attestam os Rvmos missionarios. Que Deus recompense aos incasaveis missionarios, ás pessôas que promovem esse jubileu annual, e aos peregrinos, que com grandes sacrifícios, alli accorrem todos os annos para fazer a sua paschoa e lucras as indulgencias. (sem autoria, 1935, pág4).

No dia 25, de agosto de 1937, assim como no dia 11 de agosto de 1940, publica-se na seção "Hospedes e Viajantes", do Jornal A Estrella Polar as respectivas notícias: "De passagem para Cemiterio do Peixe, esteve na cidade o Revdmo. Snr. Padre João Chrysostomo, Redemptorista" e "De viagem para Cemiterio do Peixe, estiveram ligeiramente entre nós os Revdmo. Senhores Padre João Michelloto e Vitor Rodrigues Redentoristas de Curvelo".

Abaixo podemos ver uma tabela que traz os dados em torno da atuação dos padres redentoristas, no Jubileu de São Miguel e Almas. Conforme destacou Azzi (1977), a finalidade primordial da missão era a conversão do povo à vida sacramental. Desse modo eram realizados casamentos, atendimento de confissões e distribuição de comunhões, além de eventuais extremas-unções e viáticos aos enfermos. Ainda segundo o autor, o êxito das missões se mede pelos casamentos regularizados e pelo número de confissões e comunhões. Então vejamos o saldo da atuação dos Padres Redentorista entre 1933 e 1940: 
QUADRO 1 - Registro das Missões no Jubileu de São Miguel e Almas, Cemitério do Peixe.

\begin{tabular}{|c|c|c|c|c|c|c|c|}
\hline ANO & $\begin{array}{l}\text { JORN } \\
\text { AL }\end{array}$ & PADRES & $\begin{array}{l}\text { CONFISSÕ } \\
\text { ES }\end{array}$ & $\begin{array}{l}\text { COMUNHÕ } \\
\text { ES }\end{array}$ & $\begin{array}{l}\text { CASAMENT } \\
\text { OS }\end{array}$ & $\begin{array}{l}\text { BATISM } \\
\text { OS }\end{array}$ & $\begin{array}{l}\text { CRISM } \\
\text { AS }\end{array}$ \\
\hline 1933 & $\begin{array}{l}\text { Pão de } \\
\text { Santo } \\
\text { Antôni } \\
\text { o }\end{array}$ & $\begin{array}{l}\text { Tiago } \\
\text { Frederico }\end{array}$ & 2068 & 3558 & 2 & $\mathrm{x}$ & $\mathrm{x}$ \\
\hline 1934 & $\begin{array}{l}\text { Pão de } \\
\text { Santo } \\
\text { Antôni } \\
\text { o }\end{array}$ & $\begin{array}{l}\text { Tiago, } \\
\text { Frederico e } \\
\text { André }\end{array}$ & 2317 & 3900 & 16 & 25 & 460 \\
\hline 1935 & $\begin{array}{l}\text { Pão de } \\
\text { Santo } \\
\text { Antôni } \\
\text { o/ A } \\
\text { Estrella } \\
\text { Polar }\end{array}$ & $\begin{array}{l}\text { Tiago, } \\
\text { Godofredo e } \\
\text { Matias }\end{array}$ & 2458 & 4400 & 22 & 20 & $\mathrm{x}$ \\
\hline 1937 & $\begin{array}{l}\text { A } \\
\text { Estrella } \\
\text { Polar }\end{array}$ & $\begin{array}{l}\text { João } \\
\text { Chrysostomo }\end{array}$ & $\mathrm{x}$ & $\mathrm{x}$ & $\mathrm{x}$ & $\mathrm{x}$ & $\mathrm{x}$ \\
\hline 1940 & $\begin{array}{l}\text { A } \\
\text { Estrella } \\
\text { Polar }\end{array}$ & $\begin{array}{l}\text { João } \\
\text { Michelloto e } \\
\text { Vitor } \\
\text { Rodrigues }\end{array}$ & $\mathrm{x}$ & $\mathrm{x}$ & $\mathrm{x}$ & $\mathrm{x}$ & $x$ \\
\hline
\end{tabular}

Fonte: elaboração própria a partir dos dados obtidos nos jornais.

\section{Considerações Finais}

Com certeza, ainda há muito a ser investigado sobre o Cemitério do Peixe e a sua Festa, contudo, essa pesquisa auxilia na compreensão de parte da sua história. Pelos dados levantados até o momento, acreditamos que, durante o período colonial, e posteriormente no Império, o Cemitério do Peixe foi um local em que a população negra e posteriormente os demais habitantes daquela região da Serra do Espinhaço, nas proximidades da Demarcação Diamantina, encontraram a possibilidade para enterrar seus mortos. Assim, um local de preservação dos laços afetivos e familiares, que passou a receber uma Festa anual de culto às Almas. Festa de origem popular, onde o sagrado e profano se misturam. Um ponto de encontro e sociabilidade da população. 
A atuação da Igreja Católica no Cemitério do Peixe pode ser vista a partir do ano de 1863, conforme noticiaram os jornais, quando ocorre uma ação da política de romanização do espaço. Nesse momento a Igreja encaminha padres e observadores para a Festa, além de criticar as exterioridades e a parte profana da festividade. O processo renovador continua quando a Festa entra na rota das missões redentoristas e insere-se o culto a São Miguel Arcanjo (em diminuição ao culto às Almas).

A atuação dos padres redentoristas é lembrada até os dias de hoje. No ano de 2018 presenciamos pessoas dedicando missas na intenção das almas de alguns desses padres. A participação desses missionários marcou a história do Cemitério do Peixe, seja pela sua disposição em viajar, pelas suas pregações, ou pelo esforço em falar o português, seus registros fotográficos. No que tange aos frequentadores do Cemitério do Peixe, imaginamos que a grande população negra com rituais católicos sincréticos deve ter impressionado e provacado preconceitos em alguns e admiração em outros, dos padres redentoristas que ali estiveram. Com certeza, esses padres encontraram no Cemitério do Peixe uma prática social e religiosa distinta daquela que vivenciaram na Holanda. Tiveram que lidar com uma festa cheia de bebidas, jogos e namoros. Ainda assim, pregaram as suas missões, relizaram confissões, batimos, crismas, missas e casamentos. Desse modo, levaram a vida religiosa considerada "legítima" para essas pessoas que viviam no seu isolamento na Serra do Espinhaço.

\section{Referências Bibliográficas}

ARAÚJO, Alberto Vieira. Curvelo do Padre Corvelo. Belo Horizonte: Imprensa Oficial, 1988.

AZZI, Riolando. Catolicismo Popular e Autoridade Eclesiástica na Evolução Histórica do Brasil. In: Religião e Sociedade no 1, Rio de Janeiro, ISER, 1977, p. 125-149.

CAMURÇA, Marcelo. A "artilharia pesada" espiritual (O embate das "santas Missões" redentoristas com o catolicismo tradicional mineiro em contexto de romanização no final do século XIX ),in : Religião e Violência, São Paulo: Paulinas, 2004.

CARRARA, Angelo Alves. O Distrito dos Diamantes, 1734-1757. Juiz de Fora. Clio Edições, 2017.

CEMITÉRIO DO PEIXE. Jornal A Estrella Polar, Diamatina. 25 de ago. de 1935. Ed 33. pp.4 In: Biblioteca Antônio Torres - Diamantina. 
CEMITÉRIO DO PEIXE. Jornal Pão de Santo Antônio, Diamatina. 27 de ago. de 1933. Ed. 47. pp3. Disponível em: <http://memoria.bn.br/hdb/periodico.aspx>. Acesso em: 18 set. 2018. .Jornal Pão de Santo Antônio, Diamatina. 30 de set. de 1934. Ed. 52. pp4. Disponível em: $<$ http://memoria.bn.br/hdb/periodico.aspx>. Acesso em: 18 set. 2018.

.Jornal Pão de Santo Antônio, Diamatina. 01 de set. de 1935. Ed. 49. pp3. Disponível em: <http://memoria.bn.br/hdb/periodico.aspx>. Acesso em: 18 set. 2018.

CHAVES, Raimundo Nonato de Miranda. Camilinho: escola de vida. Belo Horizonte: Edições Carranca Comissão Mineira de Folclore, 2016.

HOSPEDES E VIAJANTES. Jornal A Estrella Polar, Diamatina. 11 de ago. de 1940. Ed 32. pp.4 In: Arquivo da Arquidiocese de Diamantina - Diamantina.

NETO, Luciano Dutra. Das terras baixas da Holanda às montanhas de Minas. Uma contribuição à história das missões redentoristas, durante os primeiros trinta anos de trabalho em Minas Gerais. Tese (doutorado em Ciência da Religião), Universidade Federal de Juiz de Fora, Juiz de Fora, 2006.

OBSERVADOR, O Callado. Publicações à Pedido. Jornal O Jequitinhonha, Diamantina. 16 de nov. 1861. Ed. 40, pp. 2. Disponível em: <http://memoria.bn.br/hdb/periodico.aspx>. Acesso em: 20 set. 2018.

OLIVEIRA, Pedro Ribeiro. "Religiões Populares". In Oscar Beozzo (org). Curso de Verão II. São Paulo, paulinas, 1988, p 107-123. 


\title{
Batucando na missa: notas sobre samba na liturgia
}

\author{
Drumming at mass: considerations on the samba in the liturgy
}

\author{
Artur Costa Lopes ${ }^{45}$ \\ lopes193745@gmail.com
}

Fernando Lacerda Simões Duarte ${ }^{46}$ lacerda.lacerda@yahoo.com.br

Resumo: Este trabalho discute questões relativas à proposta de construção de uma identidade nacional na música ritual católica a partir de documentos promulgados pela Confederação Nacional dos Bispos do Brasil (CNBB) após o Concílio Vaticano II e analisa os reflexos de tais diretrizes no repertório presente no Hinário Digital, uma das referências para música litúrgica católica no Brasil. O enfoque é direcionado ao samba, não apenas em aspectos estilísticos, mas também no tocante aos momentos apropriados para seu uso. Os dados foram por meio de uma seleção do repertório de samba no referido hinário, de análise musical, pesquisa bibliográfica e documental foram analisados com base em referenciais sobre o tema no campo da Música - Amstalden, Carvalho e Duarte -, bem como da Sociologia - Niklas Luhmann.

Palavras-chave: Música religiosa - Igreja Católica; Música litúrgica autóctone; Samba; Nacionalismo musical; Inculturação litúrgica.

Abstract: This paper discusses issues related to the proposal of manufacturing a national identity in the ritual Catholic music in documents promulgated by the National Conference of Bishops of Brazil (CNBB) after the Second Vatican Council and analyzes the implications of such paradigms on the repertory present in the Hinário Digital [Digital Hymnal], a reference for Catholic liturgical music in Brazil. Emphasis is given to samba, not only in stylistic aspects, but also regarding to the appropriate moments for its use. The data obtained from a selection of samba repertory in the hymnal, musical analysis, literature and documental research were analyzed on the basis of references on the subject in the field of Musicology Amstalden, Carvalho and Duarte - as well as from Sociology - Niklas Luhmann.

Palavras-chave: Religious Music - Catholic Church; Autochthonous liturgical music; Samba; Musical nationalism; Liturgical inculturation.

\section{Introdução}

A relação entre música e rito em diversas religiões é profunda a ponto de não ser possível dissociar estes dois aspectos. No catolicismo, a música assumiu, ao longo da história, e, prossegue assumindo papel central no rito, por meio do canto do celebrante, do repertório executado pelo coro e por instrumentistas, e ainda pelo canto da assembleia de fiéis. Sendo tão profunda esta relação, a Igreja Romana procurou, sistematicamente, disciplinar as práticas musicais desenvolvidas em seus templos, desde os discursos de advertência de Agostinho de

\footnotetext{
${ }^{45}$ Mestre em Música: UFRJ.

${ }^{46}$ Doutor em Música. Estagiário de pós-doutorado junto ao PPG-Artes/UFPA com bolsa PNPD/CAPES.
} 
Hipona e Clemente de Alexandria até o estabelecimento de paradigmas mais concretos para a produção e interpretação da música, tais como a Encíclica “Annus Qui Hunc", de Bento XIV, de 1749, e o Motu proprio “Tra le Sollecituni” sobre a música sacra, de Pio X, de 1903.

Além dos documentos pontifícios, a emissão de pareceres e normativas provenientes de dicastérios, como a Sagrada Congregação dos Ritos, não deve ser perdida de vista quando do estudo dos paradigmas musicais católicos no passado. Por outro lado, a assimilação destas normas dependerá "ao mesmo tempo, do conjunto de interpretações que se sobrepõem ao texto inicial e da maior ou menor capacidade de mobilização prática e financeira de que dispõem os grupos que deverão articular sua defesa ou sua crítica" (Brollo apud Montero, 1992, p. 91), conforme foi possível observar em documentos musicográficos recolhidos a diversos acervos brasileiros (Duarte, 2016).

Para além da dimensão do mistério que este canto busca revelar por meio do texto e revestir com melodias e harmonias, é fundamental ter em vista a inserção do canto litúrgico católico no plano da cultura de cada tempo. Assim, da diversidade dos cantos cristãos, da Antiguidade à unificação musical por Gregório Magno, ou ainda na busca por adequar a manifestação musical na liturgia à índole de cada povo particular durante o Aggiornamento, nas décadas de 1940 e 50, é impossível desconsiderar o contexto cultural em que os modelos para a música religiosa foram estabelecidos e continuam sendo discutidos ainda hoje.

Neste sentido, consideramos a Igreja Católica como um sistema social autopoiético, capaz de se recriar, a partir de sua comunicação com o entorno (Luhmann, 1995), e o repertório musical enquanto resultado das interações das partes que compõem este sistema seja no estabelecimento de modelos, seja ainda nas negociações locais em relação a eles (Duarte, 2016). Portanto, busca-se debater neste trabalho questões a respeito da percepção da construção de uma identidade nacional a partir de documentos sobre música, lançados pela Confederação Nacional dos Bispos do Brasil (CNBB) após o Concílio Vaticano II, bem como analisar as formas como que estas diretrizes estão refletidas nas composições presentes no Hinário Digital (CNBB, 2017), uma das referências para música litúrgica católica no Brasil nos dias atuais. Com foco no samba, pretendemos compreender de que maneiras composições deste gênero são apresentadas e quais os momentos apropriados para seu uso. Por outro lado, não se perde de vista a dimensão histórica do fenômeno da música ritual, a fim de constatar continuidades e rupturas.

Para tanto, partimos dos seguintes questionamentos: em quais bases se assenta a ideia de nacionalidade que permeia os documentos da CNBB e quais os paradigmas vigentes sobre o assunto anteriormente e posteriormente ao Concílio Vaticano II? Qual tipo de samba é mais 
frequente neste hinário e quais suas características mais visíveis? Com vistas à obtenção de possíveis respostas, foi empreendida pesquisa bibliográfica e documental para obtenção dos dados, para além dos documentos e estudos sobre a música católica, além de uma análise de parte conteúdo do Hinário Digital, no sentido de proceder a uma varredura do repertório identificado nas partituras como "samba". Ademais, de posse de tal seleção, foi realizada, ainda que de uma amostragem parcial, análise musical com vistas à obtenção de informações que servissem à investigação.

Os dados obtidos das diversas fontes foram confrontados entre si, tendo como referenciais os trabalhos de investigação acerca da música religiosa católica no século $\mathrm{XX}$ realizados por Fernando Duarte $(2014 ; 2016$; 2018), Vinicius Mariano de Carvalho (2009) e Julio Amstalden (2001), bem como o artigo de Paula Montero (1992) sobre a relação entre música e cultura entre o Aggiornamento e o Concílio Vaticano II, e a noção de sistema social autopoiético de Niklas Luhmann (1995).

Em uma breve retrospectiva histórica, busca-se analisar o modelo determinado pelo motu proprio "Tra le Sollecitudini" de Pio X e uma determinação da Sagrada Congregação dos Ritos de fins do século XIX, que podem ter impactado diretamente a relação entre a noção de nação e a produção musical católica na primeira metade do século XX. Neste mesmo item será discutido como uma forma de nacionalismo foi expressa em uma publicação de função catequética na Bahia na década de 1920. Passa-se então à discussão acerca da passagem do modelo eurocentrista que caracterizava o motu proprio de 1903 e documentos correlatos à visão expressa pelos documentos conciliares da década de 1960, tendo o pontificado de Pio XII como um ponto de inflexão nesta trajetória. Em seguida, são analisadas as bases sobre as quais se assentam os documentos pós-conciliares sobre a música religiosa no Brasil, produzidos por estudiosos ligados à CNBB $(1976$; 1998). Finalmente, a temática do samba é trazida diretamente ao escopo do trabalho, sendo analisados alguns exemplos dentro da fonte que aqui se propôs estudar, ou seja, o Hinário Digital (CNBB, 2017).

\section{Do europeu ao autóctone: nacionalismos na música religiosa}

Promulgado em 22 de novembro de 1903, o motu proprio de título "Tra le Sollecitudini" propunha-se a disciplinar a produção e as práticas musicais de função religiosa no catolicismo romano com a força de um código jurídico. A sistematização de princípios gerais, elementos técnico-musicais e meios para que se conseguisse que o documento pontifício fosse cumprido, viria a atender aos anseios de um movimento empreendido por 
acadêmicos e músicos europeus especialistas no repertório religioso que ficou conhecido como Cecilianismo, por se organizarem em associações de Santa Cecília ou em congêneres que tinham como patrono São Gregório Magno. O reconhecimento à Associação de Santa Cecília da Alemanha ${ }^{47}$ por Pio IX em 1868 foi o primeiro sinal de que haveria de ocorrer nas práticas musicais religiosas - até então fortemente marcadas por características musicais semelhantes às da ópera e da música sinfônica - uma efetiva restauração.

A Restauração Musical Católica não objetivava, entretanto, somente o resgate de modelos musicais do passado - como de fato ocorreu com a declaração do canto gregoriano, o repertório oficial da Igreja Romana de rito latino, e, com o incentivo ao resgate da polifonia clássica, composta no século XVI, sobretudo por Giovanni Pierlugi da Palestrina - mas a noção de restaurar a música de função ritual a uma situação de dignidade que supostamente teria se perdido em razão das influências do repertório secular praticado nos teatros.

Dentre os princípios gerais encontrados no motu proprio, o da universalidade é particularmente caro a este trabalho, já que permitiu uma vaga noção entre os modelos europeus centralizados em Roma e as distintas culturas locais. Neste sentido, a música religiosa deveria ser:

arte verdadeira, não sendo possível que, doutra forma, exerça no ânimo dos ouvintes aquela eficácia que a Igreja se propõe obter ao admitir na sua liturgia a arte dos sons. Mas seja, ao mesmo tempo, universal no sentido de que, embora seja permitido a cada nação admitir nas composições religiosas aquelas formas particulares, que em certo modo constituem o caráter específico da sua música própria, estas devem ser de tal maneira subordinadas aos caracteres gerais da música sacra que ninguém doutra nação, ao ouvi-las, sinta uma impressão desagradável (Sobre música sacra apud Duarte, 2016, p. 114).

O motu proprio buscava refletir, no âmbito da música de função ritual, o modelo monolítico de catolicismo, baseado em práticas tridentinas que marcava a Romanização decorrente do Ultramontanismo ${ }^{48}$-, no qual poucas eram as aberturas às diversidades culturais:

\footnotetext{
${ }^{47}$ Já em inícios do século XIX, o movimento restaurista despontou na Alemanha, com discussões de caráter teórico e estético sobre a música que seria mais adequada à liturgia, por intelectuais como Ludwig Tieck e August Schlegel. A fundação da Sociedade Geral Ceciliana da Alemanha, a Allgemeiner Deutscher CäcilienVerein, somente ocorreria em 1869, por Franz Xaver Witt. Outros nomes relevantes no âmbito do movimento cecilianista foram Franz Xaver Haberl, Thibaud, Egg, Dominicus Mettenteiter e posteriormente, na Itália, o compositor mais representativo do movimento, Lorenzo Perosi.

${ }^{48} \mathrm{O}$ movimento reafirmava o reconhecimento da autoridade do pontífice romano mais do que a de qualquer sínodo episcopal ou do que as decisões tomadas em âmbito nacional, nos distintos países. Significava, portanto, o reconhecimento da autoridade daquele que se encontrava "além das montanhas" (ultramontanus), ou seja, para além dos Alpes, em relação aos países que se encontravam mais ao norte, na Europa, tais como França e Alemanha.
} 
O ultramontanismo tentou, portanto, substituir a realidade presente, completamente multifacetada, plural, por uma outra nova, positiva e absolutamente única. Estabeleceu uma marca de polaridade entre o velho e o novo, o bom e o mau, o presente e o futuro, o existente e a realidade a ser criada. Acreditou na possibilidade de se gerar um homem novo, envolvido na neo-espiritualidade tomista, depurado de suas antigas crenças, tidas então como atraso e crendices [...] Sem combater diretamente as devoções tradicionais, os padres romanizadores limitavam-se a não participar delas e a condenar os excessos cometidos durante as suas festas, tais como a dança, a bebida e os jogos, bem como criticar o mau uso do dinheiro recolhido pelos devotos. Tentativas de eliminar os elementos picarescos populares dos eventos religiosos esquadrinhavam-se durante as procissões, as novenas e as romarias (Gaeta, 1997)

Como seria possível, então, alguma incorporação de elementos pretensamente nacionais no repertório católico deste período? Inicialmente, é necessário ter em vista que a própria associação entre a música popular e a dita brasilidade musical somente haveria de se estabelecer um quartel após a promulgação do motu proprio de Pio X, no Ensaio sobre a música brasileira, de Mario de Andrade, publicado em 1928. Assim, o nacionalismo que até então se enunciava no repertório brasileiro era atribuído apenas a alguns nomes, como o padre J. M. N. Garcia e A. Carlos Gomes, cuja produção se legitimaria pela aproximação estilística que guardaria em relação a compositores europeus. Assim, a própria noção de música nacional há de ser aqui relativizada.

No motu proprio, a índole de cada povo haveria de ser representada principalmente pelos cânticos espirituais ou cantos religiosos populares, que eram restritos, no documento, ao uso em procissões, mas que hoje se sabe ter sido corrente no país, desde meados do século XIX, nos ritos não-litúrgicos, tais como as missas baixas. A este canto em língua vernácula de texto simples e melodias, muitas vezes, de origem europeia eram acrescentados textos de poetas nacionais.

Ainda sobre o conceito de nação, o maior símbolo musical desta havia tido seu uso litúrgico vetado pelo dicastério romano que se ocupava do culto divino à época: segundo o Decreto “Ordinatio quoad sacram musicen", da Sagrada Congregação dos Ritos, de 1884, era proibida a execução dos hinos nacionais nos serviços religiosos. Há de se observar, entretanto, que:

[...] o uso do Hino Nacional já teria acontecido na música de função religiosa: Padre João Batista Lehmann teria ouvido, em Minas Gerais, um "non confundar in ceternum" de um Te Deum, sobre melodia do Hino Nacional, que fora composto em ação de graças pela conclusão da Guerra do Paraguai, numa Semana Santa, no século XX [...]. Ademais, a Orquestra Lira Sanjoanense (MG) guarda um manuscrito pertence à Corporação Musical Santa Cecília de Piranga-MG, de um Te Deum em 
Sol Maior, cujo "Te gloriosus Apostolorum” tem citação musical do Hino Nacional brasileiro (Duarte, 2017, p. 4-5).

Assim, é possível observar um forte fechamento normativo do sistema religioso (Luhmann, 1995) a elementos nacionais que eventualmente destoassem da unidade que se pretendia com a obrigatoriedade de se seguir estritamente o modelo litúrgico tridentino. Isto não significa, contudo, que a Igreja Católica tivesse se fechado completamente ao poder secular ou aos meios sociais em que se encontrava no país. Ao contrário, uma publicação de função catequética - portanto, de difusão de uma doutrina e inculcação de ideias naqueles que a ela tivessem acesso - apontava para um alinhamento entre os poderes temporal e religioso, com vistas à construção do ideal da "grande nação católica", o que era reforçado também por meio do repertório musical:

\begin{abstract}
A primeira fonte localizada foi Vademecum Musical do Catechista ou mellodias e letras do "Flores do Altar" (VADEMECUM, 1925), que trazia uma indicação manuscrita de seu uso: "Igreja $\mathrm{N}^{\mathrm{a}} \mathrm{S}^{\mathrm{a}}$ do Rosário de Pompéia". A segunda coletânea localizada deu origem à primeira. Trata-se de Flores do Altar | Melodias e Letras: Collecção de Hymnos, Bemditos e Canticos populares para uso dos cantores e cantoras de nossas egrejas: para Collegios, Catecheses, Missões e Romarias e para todos os fieis nos actos religiosos (FLORES DO ALTAR, 1925) [...] O item IX do Vademecum (1925) tem como título Hymnos patrióticos, sendo integrado pelo Hino Nacional Brasileiro, três composições de frei Pedro Sinzig, que chegou a residir em Salvador, o Hymno da Bandeira, Meu Brasil! e o Hymno Catholico. Na mesma seção há ainda o Hymno do Trabalho e o Hymno da Escola, ambos da "Coll. C. Escolares" e encerrando a coletânea, o Hymno ao Senhor do Bomfim, de M. Wanderlen. Há ainda outros dois cânticos religiosos que merecem destaque, mesmo estando em outras seções do Vademecum: O Brasil aos pés do Sagrado Coração de Jesus, com melodia portuguesa e Brasileiro e christão serei!, sem autoria identificada. Aspectos musicais de tais não remetem o ouvido, como já haveria de se supor, à música popular brasileira, evidenciando-se, no conteúdo do texto, o objetivo nacionalista. (Duarte, 2018, passim).
\end{abstract}

É possível afirmar, em suma, a existência de um modelo musical de bases eurocêntricas a ser aplicado ao repertório católico destinado aos templos na primeira metade do século $\mathrm{XX}$, em que pese à existência de um grande repertório que hoje se considera como sendo "genuinamente" brasileiro, no âmbito do catolicismo popular, sobretudo em ambiente rural. Isto não significa, entretanto, que inexistisse entre a Igreja Católica e o Estado brasileiro qualquer vínculo. Ao contrário, como o Vademecum Musical do Catechista e Flores do Altar demonstram, tal aproximação existia e se revelava inclusive em termos musicais.

Gradativamente, foi possível perceber, contudo, o que Niklas Luhmann (1995) denominou abertura cognitiva dos paradigmas musicais e litúrgicos estabelecidos pela Santa Sé à "índole de cada povo particular", no período conhecido como Aggiornamento, que marcou, segundo Montero (1992), o reconhecimento, por parte da Igreja Católica, do valor 
das distintas culturas e sua possível assimilação na liturgia. A Encíclica "Mediator Dei” de Pio XII parece ter sido o documento mais representativo neste sentido. Nele, o pontífice aconselhava a ampliação do uso dos cantos religiosos populares em língua vernácula, sobretudo nos países em missão.

Esta medida pode ter assegurado que práticas musicais, aparentemente de fora da igreja, adentrassem, aos poucos, os templos, sobretudo os localizados em periferias e com maior participação do que a CNBB, posteriormente viria chamar do "povo simples".

Iyanaga (2015), demonstra uma interessante tese, baseada em levantamento histórico sobre as festas de santos padroeiros na Bahia, da importância fundamental do catolicismo para uma possível "reelaboração da Diáspora Africana” (Iyanaga, 2015, p. 488). Ao estudar o samba na Bahia como uma das manifestações católicas presentes no Recôncavo, o autor aponta que alguns escravos que vieram do centro sul da já possuíam um longo passado de prática católica.

O samba como manifestação, portanto, está aliado, mesmo que parcialmente, às irmandades, "devido ao processo de negociação entre populações e grupos diferentes que foram estabelecidas formas religio-artísticas coerentemente brasileiras" (Iyanaga, 2015, 491492). Ele também é encontrado, em sua maioria, sobretudo nos oitocentos, nas festas e procissões com a utilização de certos instrumentos como "tabaques", ganzás e pandeiros (típicos do samba de hoje). Observa-se ainda que, durante a primeira metade do século XX, as festas domiciliares para Santo Antônio e os santos Cosme e Damião muitas vezes incluíam samba (Iyanaga, 2015).

\section{2. "Peguem logo o violão e o pandeiro para tocar!": o estabelecimento de novos paradigmas para a música ritual}

O processo que se iniciava em fins da década de 1940 encontraria seu ápice, entretanto, no Concílio Vaticano II (1962-1965), que viria a colocar, segundo Montero (1992), as culturas europeias e não europeias em posição de igualdade. Deste processo, decorreu uma intensa renovação no repertório musical litúrgico, gerando profundas diferenças em relação à música anteriormente praticada.

Amstalden (2001, p. 187-194) identificou algumas fases neste processo de transformação. A primeira delas, na década de 1960, ainda era marcada por “melodias compostas e harmonizadas, com transparente "influência do canto gregoriano e do canto coral acompanhado de órgão", seu texto "não raramente eram salmos e trechos bíblicos, bem como 
traduções e paráfrases de antigos hinos latinos". Na década seguinte, o uso de cifragem de acordes nas músicas e o consequente abandono das harmonizações a quatro vozes foi proporcional ao crescimento do uso de motivos curtos e notas repetitivas nas melodias, escritas em registro mais grave que antes. Se a forma de trato harmônico fora modificada, o aspecto rítmico apresentou maior variação de figuras rítmicas, principalmente formadas síncopes, já que foi a forma que a escrita europeia utilizou para "arredondar" o que era diferente do usual naquele continente, e, que, certamente ,correspondem aos ritmos populares observados em terras brasileiras. Já no novo milênio, Amstalden (2001, p. 192) apontou uma aproximação entre a música litúrgica e os "padrões individualistas que marcam a sociedade de consumo" (2001, p. 192), resultando numa descartabilidade que inviabilizaria a construção de uma identidade católica no Brasil.

A mudança nos paradigmas musicais da década de 1970 se refletiria também na instrumentação: em lugar do órgão, que havia sido declarado o instrumento oficial do rito latino, no motu proprio de Pio X, o uso crescente do violão, de diferentes tambores, do pandeiro e do triângulo pode ser percebido não apenas no incentivo dado nos estudos da CNBB (1976; 1998), mas também nos documentos musicográficos deste período que foram legados ao presente (Duarte, 2016).

Há de se notar, entretanto, que os instrumentos de percussão, antes proibidos no motu proprio, por serem "fragorosos e estrepitosos" começavam a ganhar espaço nos templos católicos mesmo antes do Concílio Vaticano II, tal como se observa na a Missa Luba, composta na década de 1950, no Congo Belga, pelo frade franciscano Guido Haazen. Neste sentido, vale a pena rememorar o argumento contido em um documento da CNBB:

A classificação de instrumentos em sacros e profanos depende da relação sócio cultural/psicológico mutável quanto ao tempo (na História) e quanto ao lugar (nas culturas diversas) (cf. SC 12). Se um instrumento consegue integrar-se na liturgia, ajudando-a e exprimindo-a melhor, especialmente pelo acompanhamento do canto, este instrumento torna-se sacro, participando da sacralidade da liturgia (IV ENMS) (CNBB, 1976, §2.2.4).

Com o advento do Concílio, o movimento que antes era pontual tornou-se hegemônico, nos distintos processos de inculturação litúrgica no catolicismo romano pelo mundo, mas ainda mais particularmente no Brasil. Há de se observar ainda, que houve na América Latina uma ampla difusão da Teologia da Libertação entre os clérigos e certa aproximação do repertório pós-conciliar com a Nova Canção latino-americana, sobretudo no 
engajamento político e social dos textos, mas também pela predileção por rítmicas populares menos "comerciais" (Duarte, 2014).

Nos estudos sobre a música litúrgica, publicados pela CNBB, é possível observar ainda como a "raça" é um argumento presente na construção de um repertório litúrgico autóctone, plenamente adequado à inculturação:

\begin{abstract}
158. Quem são mesmo as pessoas que freqüentam nossas igrejas e participam de nossas assembléias ou celebrações, no campo ou nas cidades? [...] Rostos de índios ou de africanos, rostos de europeus ou asiáticos, mestiços que tanto têm de índio quanto de branco, mas, sobretudo, muito têm de negro, mesmo sem se dar conta disso ou valorizá-lo. [...] 208. A partir dos solenes apelos à inculturação lançados pelo Episcopado Latino-Americano em Santo Domingo, a dança passa a ser uma questão de coerência e fidelidade a nossas raízes indígenas, ibéricas e africanas. Destas três fontes culturais resulta um povo dançante, que tem direito a uma expressão litúrgica na qual a dança ocupa um lugar significativo. [...] 3.2.5.2. Fidelidade às nossas raízes indígenas, ibéricas e africanas [...] 218. Nesses anos fecundos de renovação da vida eclesial, até já podemos nos alegrar com o advento de uma música litúrgica que vem progressivamente incorporando melodias, ritmos e instrumentos que brotam de nossas raízes indígenas, ibéricas e, sobretudo, africanas. Seria uma contradição adotar toda essa riqueza rítmica e musical ao cantarmos e tocarmos em nossas celebrações da Fé sem liberar nosso corpo para, através da dança, atingirmos plena expressão (CNBB, 1998, passim).
\end{abstract}

O que se percebe, em suma, é uma aproximação da música ritual a partir da mesma ótica proposta por Mario de Andrade, ao lidar com a música popular: seria ela a máxima expressão da fusão do mito das três raças. Sobre esta fusão proposta no documento da CNBB, tal como a estória de Macunaíma, observou Carvalho que:

\footnotetext{
Os principais renovadores da música litúrgica brasileira, que abriram as portas da Igreja Católica no Brasil para o elemento étnico o fizeram se baseando completamente nas diretrizes marioandradianas. Duas obras são testemunho desta filiação, a primeira delas do Pe. José Geraldo de Souza, publicada na coleção Musica Sacra da Editora Vozes, que tem como título Folcmúsica e Liturgia [...] (Carvalho, 2009, p. 103-104).
}

Observa-se, então que a visão sobre raça redigida nos documentos da CNBB também exibem resquícios da teoria da democracia racial de Gilberto Freyre, apresentando, inclusive, a ideia da diferenciação entre música séria e música de dança, direcionando a autoria desta classificação ao "povo do interior do Brasil".

Assim, movimentos que buscavam aproximar a igreja do povo, ou seja, sacerdotes dos fiéis, começam a ser difundidos com maior amplitude. Assim, outras ações foram implementadas, como o incentivo à investidura de leigos, a mudança e posição do local de execução musical na igreja e a já comentada missa em língua vernácula. 
Estas atitudes tiveram reflexos em diversas áreas da liturgia, e, no caso da música, foi bastante impactante, seja no campo composicional ou performático. Após este episódio, realizaram-se conferências que se dispuseram a discutir com seria a estrutura de uma música sacra brasileira no século XX. Mas como quebrar as barreiras acústicas que fazem parte de um arcabouço simbólico marcado por uma tradição que durante séculos teve pouca variação, mesmo fora da Europa?

Neste sentido, vale mencionar que a ideia de nacionalismo - ou de produção de música sacra brasileira - defendida pela CNBB após (e durante?) o Concílio Vaticano II, foi baseada em pressupostos de apropriação de "ideias folclóricas" e sua posterior adaptação para o texto sagrado.

Esta forma de apropriação de práticas culturais existentes em solo brasileiro foi bastante significativa, pois revelou-se como um movimento institucional a constituir um vasto material de cantos que fossem baseados nas tradições de diversos locais do país, buscando diminuir a distância entre a prática litúrgica católica e o local que ela estava inserida.

Este modelo se refletiu claramente na construção dos quatro volumes do Hinário Litúrgico da CNBB, utilizado largamente no Brasil durante pelo menos três décadas, e ainda hoje parece persistir no Hinário Digital (CNBB, 2017).

\section{3. "Yes, nós temos música sacra": cantochão e canto no chão.}

Ainda que a maioria da literatura sobre musica sacra no Brasil esteja desatualizada com relação às novidades tecnológicas, destaca-se a importância dos estudos realizados até o presente momento, já que conseguiram estruturar uma dinâmica própria de liturgia ao longo de mais de quarenta anos de pesquisas, composições e experimentações.

A noção de inculturação desenvolvida pela CNBB, portanto, é composta por um cenário acústico de pouco movimento. Embora tenha como objetivo criar laços entre história da música católica romana, folclore brasileiro - através da criação sobre características performáticas de distintos grupos étnicos deste país - observa-se que ainda despreza a música produzida em algumas periferias urbanas, sobretudo as que foram construídas a partir de processos mais recentes de globalização, como o rap e o funk.

Como a ideia de identidade nacional refere-se muito mais ao nacionalismo proferido por Mario de Andrade, como explicado anteriormente, do que a uma produção musical nacional mais ampla, verifica-se que ainda há outras possibilidades de interpretar o termo inculturação, vocábulo que, inclusive, aparece pouco discutido nos documentos disponíveis. 
Deste modo, alguns equívocos são cometidos, sobretudo no que diz respeito a purismos que desconsideram o fenômeno de globalização e a diáspora africana ${ }^{49}$ como um processo em constante movimento.

Todavia, organizar um acervo com uma produção musical nova, inspirada na produção acústica do Brasil não é uma tarefa simples, muito menos que se pretenda ser de curto prazo. Basta olhar para a história das transformações (aceitações e proibições) no campo musical católico desde sua origem. Porém, observa-se que alguns pontífices têm demonstrado grande esforço em acompanhar as "novidades" no mundo, seja no que se refere à tecnologia ou no tocante aos costumes aparentemente imutáveis.

Mesmo que isso não seja um fenômeno novo, vê-se que fora da Europa ele é mais constante, fato que pode ser exemplificado pelo crescimento de diversos movimentos que ocorreram nos últimos séculos, que tornaram o catolicismo mais plural (Castro; Teixeira, 2009), como a valorização das irmandades, que também exploraram o catolicismo santorial, que desenvolveram outras formas de organização católica no Brasil, não somente restritas à resistência (ou imposição religiosa) negra, mas de outras naturezas, como o movimento da Teologia da Libertação, que teve clara aproximação da canção de protesto, ou Nova Canção latino-americana (Duarte, 2014) e, mais recentemente, na ebulição da Renovação Carismática Católica, que permitiu maior visibilidade e, mais uma vez, mostrou que é possível vestir o catolicismo brasileiro com "outras roupas".

A fim de estabelecer um padrão litúrgico musical, oriundo, sobretudo do Vaticano II, foram organizadas algumas coletâneas de discos e partituras em finais do século XX, todavia nos debruçaremos em analisar alguns aspectos do Hinário Digital, sítio virtual criado como uma forma de democratizar o acesso ao acervo musical litúrgico católico. Segundo as palavras do site, ele foi produzido:

sem fins lucrativos com intuito de ajudar as comunidades a bem celebrar a Eucaristia utilizando músicas rituais próprias para tempo litúrgico, momentos da celebração e solenidades. A comercialização do material do site está proibida uso autorizado apenas para utilização das comunidades e paróquias (CNBB, 2017).

Sistematizado com o propósito de atender músicos católicos, funciona como uma relevante fonte de estudo e execução nos ritos, sobretudo àqueles que não podem adquirir os livros de partitura editados anteriormente. Deste modo, valoriza tanto músicos que leem

49 Tanto Hall (2003) quanto Gilroy (2001) evidenciam que a América produziu diferentes formas de interpretação da música africana e europeia, e que estes distintos modos de práticas musicais são difíceis de possuírem uma origem especifica, mesmo porque, não ficaram instalados de forma imóveis no continente, mas transitaram e se renovam constantemente por diversas partes do globo, mesmo antes do século XX. 
partitura, cifras ou que tocam "de ouvido", já que também utiliza o recurso de vídeos ${ }^{50}$ das composições utilizadas na liturgia.

Ao serem analisados os critérios de seleção das composições, observa-se uma vontade de implementar nas comunidades um formato de canto produzido a partir dos estudos pósconciliares da CNBB (Valinhos, SP - 1965, Vitoria, ES - 1966, Guanabara, RJ - 1967, Guanabara, RJ - 1968). Estes apresentam como principais requisitos a construção de uma música sacra que contemple o diálogo entre assembleia, ministério de música e corpo sacerdotal, visando diminuir as barreiras entre estes, sobretudo, a partir do uníssono como apresenta Fonseca (2015). Para o autor, cantar a uma só voz na Igreja Católica vai além da entonação de músicas, mas é viver a coletividade da comunidade da assembleia em que todos devem somar um só corpo, fato que confere a "compreensão do sentido simbólicosacramental do uníssono na ação litúrgica" (Fonseca, 2015. p. 10).

Vale destacar ainda que as premissas sugeridas pela CNBB, contidas no Hinário Digital, através da disponibilização do repertório, são fruto de estudos etnográficos (de abordagem folclorista) juntamente com análise de documentos da Igreja católica sobre música clássica. Para tanto, diversos métodos de coleta foram utilizados, sobretudo através da tríade "colher, assimilar e iluminar", com o objetivo de criar uma música sacra que contemple elementos de diferentes manifestações musicais presentes no interior do Brasil.

Deste modo, o repertório visa respeitar quatro princípios: 1) participação dos fiéis; 2) canto em vernáculo; 3) função ministerial da música sacra, eliminando a arte pela arte ou algum caráter considerado profano (como letras impróprias, danças, etc...), sem desmerecer os tesouros do passado, como a polifonia "clássica" renascentista, o estilo moderno, a partir do Barroco e o canto gregoriano 4) abertura para a expressão de nosso povo através da assimilação das contribuições musicais que refletem a "alma brasileira" (Albuquerque et all, 2005).

Um exemplo que reflete muito bem este debate é a música de abertura intitulada "Acolhe os oprimidos", um baião de Hamilton F. dos Santos. Esta canção, como outras do Hinário, cumprem também uma função didática, pois, além de dialogar diretamente com a liturgia do dia, pode ser utilizada para três domingos litúrgicos, já que apresenta três refrãos diferentes, com a mesma melodia, um para o $17^{\circ}$ e os outros para os $18^{\circ}$ e $19^{\circ}$ domingos do Tempo Comum (ano A). Explorando os textos dos salmos 32, 68, 70 e 74, a letra do cântico

\footnotetext{
${ }^{50}$ Os vídeos transportam o internauta à plataforma YouTube, e é necessário pontuar que, em sua maioria, não estão disponíveis, e, muitos não são produzidos de maneira formal e didática.
} 
revela a já mencionada aproximação do movimento da Nova Canção, que privilegia temas como libertação, opressão e empoderamento das minorias.

(17 DTC) - Acolhe os oprimidos, em tua casa, ó Senhor, é seu abrigo!

Só Ele se faz temer, pois a seu povo dá força e poder.

(18 DTC) - Meu Deus, vem libertar-me, não demores, Senhor, em socorrer! Só tu és o meu arrimo, libertador, vem depressa me valer!

(19 ${ }^{\circ}$ DTC) - Senhor tua aliança leva em conta e não largues o teu povo! Defende a tua causa e não desprezes quem pede o teu socorro.

1. A nação que ele governa, é feliz com tal Senhor.

Lá do céu ele vê tudo, vê o homem e seu valor.

Fez o nosso coração, forte e contemplador.

2. O que dá vitória ao rei, mão e ter muitos soldados.

O valente não se livra por tua força ou seus cuidados.

Quem confia nos cavalos vai, no fim, ser derrotado.

3. Ó Senhor protege sempre quem espera em seu amor,

Pra livrar da triste morte e, da morte, dar vigor.

No Senhor é que esperamos, Ele é escudo protetor.

4. Nele nosso coração encontrou sempre alegria.

No seu nome sacrossanto quem é bom, sempre confia. Traz, Senhor, com teu amor, esperança e alegria!

Com relação à melodia deste canto de abertura, observou-se uma questão que é recorrente no repertório: fidelidade a elementos regionais adaptados à forma "sacra". Esta prerrogativa, ao passo que privilegia comunidades que estão habituadas a este tipo de canto, mas prejudica outras (a maioria) que pode estranhar certos intervalos, escalas e mudanças de modos recorridos constantemente, e, como estes são alternados (maior e menor) a harmonia sugerida acompanha este processo.

Embora a estrutura rítmica tenha bastante aceitação em grande parte do território nacional, a variação de compasso (quaternário e binário) é um elemento que torna o cântico mais característico de uma localidade bastante específica.

Analisando performances em Igrejas de Duque de Caxias (Rio de Janeiro), observouse que este canto, como outros com características semelhantes, são entoados na liturgia com algumas adaptações. As melodias são modificadas nos intervalos menos "comuns" à região, bem como a mudança de compasso não é respeitada. Com estas adaptações a música é entoada pela maioria da assembleia sem maiores problemas e passa a fazer parte do repertório.

\section{Os sambas no Hinário Digital}

Ao analisar inúmeras fórmulas rítmicas do panorama acústico presente em diversas partes do território brasileiro, o padre José Geraldo de Souza (2005) pontuou cinco 
características mais recorrentes: síncopa, independência da melodia (ritmo livre), polirritmia, frequência do compasso binário andamento rítmico. Embora pautado em pressupostos da música europeia, inclusive no modo de escrita, seu estudo, baseado em folcloristas brasileiros, foi fundamental para diversas composições presentes no Hinário Digital.

Quando descreve a "área do samba", ele apresenta células rítmicas diferentes intituladas como batuque, samba, jongo, macumba, candomblé e toada (Zona agrícola da Bahia até São Paulo). Entretanto, na área da viola também aparece o termo samba, chamado de samba de lenço, como divisão rítmica diferente do samba citado anteriormente. Mesmo assim, as variações (ou gêneros similares) do samba selecionadas por Souza (2005) estão presentes da Bahia a São Paulo, e apresentam ligação direta com a religiosidade afro brasileira, mesmo caminho apresentado por diversos estudiosos sobre o gênero no século XX. Contudo, no Hinário aparecem outras variações, como veremos a seguir.

Diferentemente de alguns cantos que privilegiam elementos de uma cultura bastante específica, pouco ou não difundidos pela grande mídia, como no caso da música anterior, os sambas apresentados no Hinário Digital também congregam clichês presentes em músicas seculares bastante conhecidas do povo brasileiro - e não somente baiano ou carioca - já que muitos sambas ganharam projeção nacional desde Getúlio Vargas, mas também foram apoiados por meios de comunicação de massa, principalmente a partir das décadas de $1970 \mathrm{e}$ 80 com a ascensão do pagode de partido alto (atualmente, conhecido como samba de raiz), coincidentemente o mais utilizado no hinário. Um exemplo é uma versão de Reginaldo Veloso "Fiquei foi contente", canto de abertura, sugerido para o $4^{\circ}$ Domingo da Quaresma do ano B.

Fiquei, foi contente, com o que me disseram: "Regozijai-vos sempre no Senhor". Mas eu fiquei.

Nossos passos já pisam o teu chão. Ó cidade bem fortificada. Para lá vai subindo a nação, as tribos do Senhor, pois já virou tradição pra celebrar, pra celebrar o nome do Senhor.

Pois é lá que estão os tribunais, tribunais da justiça do rei. Venham todos e peçam paz para Jerusalém. Vivam tranquilos demais os que te amam; dentro de ti segurança e todo o bem.

Por aqueles que são os meus irmãos, os amigos a quem quero bem. "Paz contigo" será o meu refrão por causa desse templo que do Senhor é mansão do nosso Deus eu te desejo a paz e todo bem.

Este canto é construído em compasso binário, composto por uma linha melódica repletas de síncopes e contratempos com extensão vocal de uma segunda composta, semelhante aos sambas de Almir Guineto ou Zeca Pagodinho. 
A música é desenvolvida a partir da frase contida no quarto capítulo de Filipenses "regozijai-vos sempre no senhor". Por fidelidade a certa tradução bíblica, ou evitar redundância, Veloso constrói estrofes que valorizam a ideia da Igreja (casa do Senhor) como local para adoração em forma de alegria, em que as pessoas podem conviver pacificamente.

Outro exemplo, de samba presente no hinário, que também aparece no formato refrão/estrofes é "Quanta alegria e felicidade" de Marco Campos e Adenor Leonardo Terra.

\author{
Ref.: Quanta alegria e felicidade \\ Nos reunir na casa do Senhor \\ Como família, em fraternidade, \\ Ouvir sua Palavra, cantar seu louvor! \\ 1. Somos eleitos a caminho: \\ Comunidade de comunidades. \\ E o Cristo é a nossa razão, \\ A Vida, Caminho e Verdade! \\ 2. Cremos e damos testemunho: \\ Somos discípulos e missionários! \\ Unidos num só coração, \\ Ao outro co'amor solidário!
}

Classificado como samba canção, ele foge aos padrões das músicas da "área do samba", pois, além de ter como base o compasso quaternário, sua harmonia está ligada ao movimento da bossa nova (que também tem conexão direta com o samba canção das décadas de 1940 e 50), caracterizado pela harmonia, que é maior no refrão e menor nas estrofes, e pelos diversos "acidentes" que a melodia proporciona.

Com poesia que valoriza a vida familiar e fraterna, o texto adverte que o povo é eleito, mas não na visão calvinista, mas na católica, em que as obras são necessárias para se alcançar a vida eterna, por isso são escolhidos para o caminho. A ideia de comunidade também está expressa no canto a partir da comunhão entre diferentes "igrejas". Ou seja, o catolicismo brasileiro, mesmo diverso, segue a doutrina romana, ainda que permitindo adaptações. Neste sentido a expressão "comunidade de comunidades" pode ser interpretada como uma forma de remeter a este sentimento unitário que admite a diversidade.

Todavia, também há exemplos de outras formas de samba, como o outro samba canção, inspirado em uma nomeclatura típica do início do século XX no Rio de Janeiro, utilizada com certa constância por músicos como Chiquinha Gonzaga e Ernesto Nazareth como registro de gênero: tango brasileiro, como é o caso de "Nós, teu povo reunido" "51.

\footnotetext{
${ }^{51}$ Com letra de Eurivaldo Silva Ferreira e música de Wanderson Luiz Freitas, este canto apresenta alterações melódicas típicas do choro carioca, que, neste caso, é mais difícil de enquadrar-se a uma música nacional, e mesmo regional, já que sua forma também é modificada para adaptar-se ao modo de canto litúrgico.
} 


\section{Considerações finais}

Ao final deste trabalho, pudemos perceber que apesar do discurso de aparente transcendência em relação ao século que marcou o Ultramontanismo, existiram elementos capazes de expressar musicalmente uma noção de nacionalismo, a exemplo dos manuais restauristas de frei Pedro Sinzig, publicados para a Arquidiocese de Salvador. Gradativamente, sobretudo a partir da década de 1940, houve maior abertura à índole de cada povo particular, o que viria a resultar nas diretivas conciliares.

Observa-se que a estrutura rítmica, tanto da cadência harmônica quanto da melodia, mas, soberanamente do acompanhamento, pode ser um elemento que torna a música litúrgica pós-conciliar produzida pela CNBB nacional, já que através de sambas, marcha-rancho e baiões, proporciona nova dinâmica aos ritos e os aproxima mais do povo brasileiro. Entretanto, dependendo do lugar e da forma que for executado pode causar o mesmo distanciamento, ou até maior, que uma marcha ou polifonia europeia.

Mas discutir o samba na liturgia deve ir além de agrupá-lo em um parâmetro musical. É importante constar que seu ingresso no repertório litúrgico faz parte de um movimento que antecede o Vaticano II, é uma construção coletiva inter-religiosa e de resistência da população negra residente no Brasil, alvo de diferentes formas de censuras durante muitos séculos, capitaneadas, inclusive pela Igreja Católica.

Deste modo, agregar práticas antes proibidas ainda está longe de ser um consenso, já que o repertório do Hinário Digital não é unânime na maioria de muitas comunidades do Brasil, bem como as formações instrumentais contemporâneas pouco dialogam com o samba, baião e outros gêneros citados neste trabalho.

\section{Referências}

AMSTALDEN, Júlio César Ferraz. A música na liturgia católica urbana no Brasil após o Concílio Ecumênico Vaticano II (1962-1965). São Paulo, 2001. 175 f. Dissertação (Mestrado em Artes) - Instituto de Artes, Universidade Estadual Paulista "Júlio de Mesquita Filho".

CARVALHO, Vinicius Mariano de. Aspectos da música na liturgia católica na América Latina do Vaticano II aos dias atuais Do "canto do povo de Deus" ao "som da massa". Diálogos Latinoamericanos, Aarhus (Dinamarca), n.16, p. 90-114, 2009.

CNBB - Conferência nacional dos Bispos do Brasil. A música litúrgica no Brasil: um subsídio para quantos se ocupam da música litúrgica da Igreja de Deus que está no Brasil. 
1998. Disponível em: < http://www.cnbb.org.br/component/docman/doc_download/340-amusica-liturgica-no-brasil-estudo-cnbb-79>. Acesso em 9 set. 2011.

Hinário Digital: Página inicial. 2017. Disponível em: $<$ http://www.hinariodigital.com.br/mpub>. Acesso em 5 mai. 2018.

. Setor "Música litúrgica". Pastoral da Música Litúrgica no Brasil. 1976. Disponível em: $\quad<$ http://www.cnbb.org.br/publicacoes/documentos-para-downloads/doc_view/339->. Acesso em 9 set. 2011.

DUARTE, Fernando Lacerda Simões. Do canto religioso popular à música autóctone: memórias, esquecimentos e o desenvolvimento de uma identidade musical local no catolicismo pós-conciliar. In: SIMPÓSIO BRASILEIRO DE PÓS-GRADUANDOS EM MÚSICA, 3., 2014, Rio de Janeiro. Anais ... Rio de Janeiro: Unirio, 2014. p. 784-794.

. O Hino Nacional brasileiro na Missa Solene Vaticano II de José Mousinho: uma proposta de abordagem a partir das vertentes da música litúrgica católica pós-conciliar. In: CONGRESSO DA ANPPOM, 27., 2017, Campinas-SP. Anais... Campinas: ANPPOM, 2017. Disponível em: <http://www.anppom.com.br/congressos>. Acesso em: 29 mai. 2018.

Resgates e abandonos do passado na prática musical litúrgica católica no Brasil entre os pontificados de Pio X e Bento XVI (1903-2013). São Paulo, 2016. 495 f. Tese (Doutorado em Música) - Instituto de Artes, UNESP, São Paulo, 2016.

. Vademecum Musical do Catechista e Flores do Altar: música, catolicismo popular e hinos patrióticos no contexto da Romanização na Arquidiocese de São Salvador da Bahia na década de 1920. In: ENCONTRO DE MUSICOLOGIA HISTÓRICA, 12., 2018, Juiz de Fora. Anais... [no prelo] Juiz de Fora: UFJF, 2018. p.893-898.

FONSECA, Joaquim. "A uma só voz": o uníssono como sinal sensível da sintonia da assembleia no Espírito Santo. Horizonte Teológico, Belo Horizonte, v.14, n.27, jan./jun. 2015. p.9-25.

GAETA, Maria Aparecida Junqueira Veiga. A Cultura clerical e a folia popular: Estudo sobre o catolicismo brasileiro nos finais do século XIX e início do Século XX. Revista Brasileira de História, São Paulo, v.17, n.34, 1997. Disponível em: $<$ http://www.scielo.br/scielo.php?script=sci_arttext\&pid=S0102 01881997000200010>. Acesso em: 29 abr. 2010.

GILROY, Paul. O Atlântico negro: modernidade e dupla consciência. Tradução de Cid Knipel. São Paulo: Ed. 34; Rio de janeiro: Universidade Candido Mendes, Centro de Estudos Afro-Asiáticos, 2001. 
HALL, Stuart. Da diáspora: identidades e mediações culturais. Editora UFMG: Belo Horizonte, 2003.

IYANAGA, Michael. A história católica do samba na Bahia: reflexões sobre a diáspora africana. In: ENCONTRO NACIONAL DA ASSOCIAÇÃO BRASILEIRA DE ETNOMUSICOLOGIA, 7., 2015, Florianópolis. Anais do VII ENABET: Florianópolis: ABET, 2015. p. 487-500.

LUHMANN, Niklas. Social Systems. Stanford, CA: Stanford University Press, 1995.

MENEZES, Renata de Castro; TEIXEIRA, Faustino. Catolicismo plural: dinâmicas contemporâneas. Petrópolis, RJ: Vozes, 2009.

MONTERO, Paula. Tradição e modernidade: João Paulo II e o problema da cultura. Revista Brasileira de Ciências Sociais, Rio de Janeiro, a.7, n.20, p.90-112, 1992.

SOUZA, José Geraldo de. Folcmúsica e liturgia: subsídios para o estudo do problema. Petrópolis: Vozes, 1966. Coleção Música Sacra, n.1.

- Elementos de rítmica musical no folclore brasileiro. In:

ALBUQUERQUE, Amaro Cavalcante de. Et all. Música brasileira na liturgia. Paulus: São Paulo, 2005. 


\title{
Santa Lola: a construção de um mito religioso - uma análise do catolicismo popular
}

\author{
Santa Lola: the construction of a religious myth - an analysis of popular Catholicism
}

\author{
Mara Bontempo Reis ${ }^{52}$ \\ marabomtempo@yahoo.com.br
}

\begin{abstract}
Resumo: Floripes Dornelas de Jesus, aos 21 anos foi acometida por um grave acidente que gerou complicações na coluna. Com o tempo, devido a problemas digestivos, passou a se alimentar apenas da Eucaristia. Este momento foi determinante para a sua transformação, reafirmando sua comunhão com Deus e um profundo despertar espiritual passando a se dedicar às orações e ao recolhimento. A notícia de se alimentar apenas da eucaristia se espalhou pela cidade e região surgindo o mito Santa Lola. A curiosidade popular levou à uma forma de devoção que nos remete a elementos do catolicismo popular. Refletir e aprofundar no "mistério" do mundo interior da mística Lola é entender como que um acidente doméstico de uma jovem, agregou fiéis e seguidores que a elevaram à condição de santa.
\end{abstract}

Palavras-chave: Lola, Catolicismo Popular, Religiosidade Popular

Abstract: Floripes Dornelas de Jesus, at the age of 21 was affected by a serious accident that caused complications in her spine. Over time, owing to digestive problems, she begins to feed only on the Eucharist. This moment was decisive for her transformation, reaffirming her communion with God and a deep spiritual awakening, dedicating herself to prayer and recollection. The news of eating only of the Eucharist spread throughout the city and region, creating the myth of Santa Lola. Popular curiosity has led to a form of devotion that brings us back to elements of popular Catholicism. Reflecting and deepening into the "mystery" of the inner world of the mystic Lola is to understand how a domestic accident of a young woman added faithful people and followers who raised her to the status of saint.

Keywords: Lola, Popular Catholicism, Popular Religiosity

Um itinerário de vida marcado por uma fé incansável, sempre baseada nos princípios e dogmas da Igreja Católica. De origem simples e criada no interior de Minas Gerais é assim Lola, nascida Floripes Dornelas de Jesus, no dia 09 de junho de 1913 na cidade de Mercês Zona da Mata Mineira. Lola era a caçula de treze irmãos e, quando tinha dois anos de idade, sua família mudou-se para Rio Pomba município próximo de sua terra natal onde ela viveu até sua morte ocorrida no dia 09 de abril de 1999 aos 86 anos.

Aos dezenove anos, Lola entrou para a Irmandade das Filhas de Maria ${ }^{53}$, na Paróquia de São Manoel em Rio Pomba.

\footnotetext{
${ }^{52}$ Graduanda do Bacharelado em Ciência da Religião da UFJF
} 
No ano de 1934 Floripes sofreu um grave acidente quando estava colhendo jabuticabas. Ela caiu da árvore em cima de um cercado de bambus e como consequência teve uma perfuração do baço e complicações na coluna. Mesmo com os recursos médicos reduzidos na época, Lola foi submetida a um rigoroso tratamento em Juiz de Fora durante um longo período. Cessadas todas as tentativas de recuperação da paciente, os médicos confirmaram que a lesão a deixaria paraplégica e que era irreversível. Esse momento foi determinante para a sua transformação, contribuindo de forma relevante para o seu crescimento interior, reafirmando sua comunhão com Deus e um profundo despertar espiritual. Lola então passou a dedicar-se às orações e ao recolhimento.

Mas não demora muito tempo e ela passa aos cuidados do "Médico dos Médicos", então começa a consagrar os seus sofrimentos para a salvação de sua alma e das almas de todos aqueles que a procurarem e, por via de orações e sacrifícios, se entregarem com fé ao Sagrado Coração de Jesus. (IBRAHIM, 2007, p. 15).

Os medicamentos eram excessivos e, por este motivo, seu estômago, danificado, começou a rejeitá-los (SILVEIRA e ELIAS, 2015). Muitas vezes o único alimento que ela conseguia ingerir era um caldo feito de cidra. Com o passar do tempo e com as complicações digestivas, ela já não conseguia comer e, para o espanto de todos à sua volta a mesma não tinha sua saúde prejudicada pela falta de alimentos e/ou remédios; outro fator que causou comoção foi quando a devota das filhas de Maria deixou, também, de ingerir líquidos e passou a se alimentar apenas da Eucaristia que lhe era ofertada diariamente pelo vigário Padre Gladstone Batista Galo, que foi seu orientador espiritual durante vinte e oito anos.

Cláudio José Coelho Bomtempo ${ }^{54}$, médico e amigo de Lola durante alguns anos, relata em seu livro "O que o meu coração aprendeu" (2005) o ocorrido em sua primeira visita, no momento em que pergunta a ela sobre quando parou de se alimentar, eis que a mesma responde:

Dr. Claudinho ${ }^{55}$, as coisas não aconteceram assim, parando de me alimentar...Na verdade assim que caí do pé de jabuticaba, parei de sentir fome, parei de sentir sede, parei de sentir sono. Eu não sinto necessidade de nenhuma destas coisas, mas isso para mim não é sacrifício, porque eu não sinto a necessidade delas... (BOMTEMPO, 2005, p. 92)

\footnotetext{
53 As iniciantes na Irmandade de Filhas de Maria são chamadas postulantes. Por um ano e meio, são instruídas por uma integrante mais experiente aos seus afazeres diários e futuros. seu traje é composto de fitas e faixas azuis e uma medalha, considerada milagrosa por elas, sobre a vestimenta branca (SILVEIRA e ELIAS, 2015, p. 276).

${ }^{54}$ Médico clínico, formado pela Faculdade de Medicina de Valença - RJ em 1993. Especialista em Geriatria e Medicina do Trabalho. Foi médico de Lola no período de 1996 a 1999.

${ }^{55}$ Forma carinhosa que Lola se referia ao médico e amigo Cláudio José Coelho Bomtempo.
} 
Cláudio Bomtempo não foi o único médico que acompanhou Floripes. $\mathrm{O}$ cardiologista Adhailton Campos Bello, também foi seu médico e esteve presente durante os anos de 1993 e 1994. Bomtempo (2005) cita em seu livro, um parecer do referido cardiologista datado em 06 de janeiro de 1994:

pela quarta vez consecutiva examinei Lola. Os seus sinais e parâmetros clínicos permanecem como na primeira vez. PA (Pressão Arterial): 160x65, pulso 76 bpm rítmicos. Sinais auscutatórios de dupla lesão aórtica. ECG (eletrocardiograma) com sinais SVE (Sobrecarga de ventrículo esquerdo). Nada percebi que pudesse contestar a veracidade de ser seu único alimento a Eucaristia. Sente dores nos ombros e joelhos (principalmente o direito), que apresentam sinais de inflamação (flogose) tratados com anti-inflamatórios (gel e pomada). Nada ingere. [...] (BOMTEMPO, 2005, p. 105)

A notícia de se alimentar apenas da eucaristia se espalhou pela cidade de Rio Pomba e por toda a região e começou a despertar a curiosidade em meio às pessoas.

Existem relatos que dizem que Lola além de não se alimentar, também não dormia, não ingeria líquidos e não acusava necessidade fisiológica. Fato que foi constatado pelo Padre Gladstone e alguns fiéis que se revezavam em vigília.

Em seu silêncio diário Floripes rezava pelas mazelas humanas a fim de aliviar o sofrimento daqueles que buscavam consolo em suas orações, uma prática constante na qual foi criando forças para enfrentar as dificuldades que iam surgindo ao longo de sua vida, um caminho marcado pela doação, acolhida e hospitalidade para com os outros.

\footnotetext{
Ela, que de pronto se consagrara a Maria, agora é despertada e se sente consumida por um amor muito forte que enleva e a faz como que renascer. De tal forma, que ela passa a compreender que está irremediavelmente presa à aquela torrente de amor que jorra incessante e continuamente do Rei e Centro de todos os corações, o Sagrado Coração de Jesus. (IBRAHIM, 2007, p. 15)
}

Romarias começaram a chegar na fazenda e as pessoas passaram a atribuir milagres realizados através das orações de Lola. As circunstâncias tomaram uma grande proporção e os fatos citados contribuíram para a construção do mito Santa Lola.

Entretanto, não há razão para que nos conservemos reservados - não indiferentes, que nunca o fomos! - diante da romaria diária que acorre ao recanto da piedosa donzela, a três quilômetros desta cidade, onde uma multidão que dia a dia mais aumenta vai buscar lenitivo para os seus sofrimentos físicos e Moraes através da valiosas orações de Floripes Dornelas de Jesus - a Lôla [...] (Jornal O Imparcial, edição de 22 de junho de 1951 apud FERREIRA, 1996, p. 202) 
O fato de receber muitas pessoas e um aumento considerável das romarias a fez entrar em um momento de esgotamento físico e, diante de tal situação, o Arcebispo da Arquidiocese de Mariana, Dom Oscar de Oliveira, temendo pela sua saúde debilitada proibiu, a partir de 1958, que Lola recebesse os leigos. Sempre muito obediente à Igreja, a devota então acatou as orientações e passou a receber um número reduzido de pessoas, em sua maioria religiosos, e tais visitas eram previamente agendadas, evitando assim muitos contratempos (SILVEIRA e ELIAS, 2015).

Após sua morte, a Prefeitura Municipal de Rio Pomba criou a Lei $n^{0} 1.160 / 2003$, assinada pelo prefeito da época Giovani Baia e aprovada por unanimidade pela Câmara dos Vereadores, na qual instituiu o dia 9 de abril como feriado municipal em homenagem a data de seu falecimento.

Floripes viveu mais de sessenta anos reclusa em seu quarto, sentada em uma cama sem colchão, recostada em algumas almofadas e com as pernas levemente fletidas. Ela passava os dias confeccionando pequenos trabalhos manuais, se dedicando às orações, ao Apostolado da Oração ${ }^{56}$ principalmente o masculino e envolta aos mistérios que cercavam sua vida ascética e dedicada totalmente à religião. Foi responsável em propagar a fé no Sagrado Coração de Jesus, o que fazia com muito amor e zelo, distribuindo aos fiéis o livro "A grande Promessa do Sacratíssimo Coração de Jesus" Coração de Jesus. Tanto as imagens, quanto os livros e as novenas eram confeccionados com recursos financeiros próprios.

Orientada dentro dos princípios e dogmas da Igreja Católica, Floripes Dornelas de Jesus, tornou-se personagem importante para a religiosidade na Zona da Mata Mineira e para a cidade de Rio Pomba mantendo-se a orar por aqueles que a procuravam a fim de alcançar alguma graça divina para problemas pessoais.

Após seu falecimento, iniciou-se um importante levantamento de fatos, histórias e elementos da trajetória religiosa de Lola e foi oficializada a abertura de um processo de beatificação que se encontra em andamento sob o no 2699. Em 30 de novembro de 2005 foi declarada pelo Vaticano NULLA OSTA - nenhum obstáculo - significa que o processo foi acolhido pela Congregação das Causas dos Santos do Vaticano e que Lola é uma SERVA DE DEUS (FERREIRA, 2007)

\footnotetext{
${ }^{56}$ Grupo Católico de devotos do Sagrado Coração de Jesus. Existe o grupo das mulheres e outro dos homens.

57 Autor Frei Salvador do Coração de Jesus - Terceiros dos Menores Capuchinos, traduzido do italiano, com autorização do autor por uma zeladora do Apostolado da Oração.
} 
Em 2005 um grupo de fiéis, moradores de Rio Pomba - MG, se mobilizou em busca de provas que ratifiquem sua santidade. Tal grupo se intitula como Associação dos Amigos da Causa de Lola (AACL).

A fazenda onde Lola viveu em Rio Pomba se transformou numa espécie de santuário, um recanto espiritual, visitado frequentemente por milhares de fiéis de várias cidades, onde acontecem regularmente celebrações religiosas. As primeiras sextas-feiras de cada mês é dedicada ao Sagrado Coração de Jesus e a homenagear à sua antiga moradora.

Segundo dados da Polícia Militar, cerca de vinte e sete mil pessoas estiveram presentes em seu velório e cerca de quinze mil pessoas no cortejo até o cemitério municipal onde foi sepultada. Seu túmulo é considerado um monumento de visitação que recebe diariamente oferendas de pessoas anônimas em busca de auxílio espiritual e/ou para agradecer por algum pedido atendido.

Estima-se que os fiéis de Lola guardam consigo objetos que tiveram alguma relação com a devota, sejam pedaços de roupas, trabalho manual confeccionado, bilhetes, cartas, imagens do Sagrado Coração de Jesus que ela tenha presenteado, dentre outros.

Destes objetos tomamos como exemplo o relato encontrado no trabalho de OLIVEIRA (2008) quando se refere a retirada de pedaços da raiz da jabuticabeira que provocou o acidente em Lola. Tais objetos possuem um valor e uma simbologia especial sendo considerados pelos devotos como verdadeiras relíquias ${ }^{58}$.

Segundo ALVES “o sagrado não é uma eficácia inerente às coisas. Ao contrário, coisas e gestos se tornam religiosos quando homens os batizam como tal" (ALVES, 1986, p. $10)$.

O estar consciente da presença de Deus foi para ela de grande importância, vivendo como testemunha da existência divina cumprindo assim sua missão de rezar pelos aflitos, de propagar a fé no Sagrado Coração de Jesus e de incentivar a participação dos homens no Apostolado da Oração.

Sua estreita relação com o Sagrado Coração de Jesus não foi apenas um processo interior, mas avivou em si um sentimento profundo de cuidado e atenção com o próximo, sentindo-se envolto pela presença do divino, capaz de transmiti-la nos corações das pessoas.

Segundo Boff (2002),

\footnotetext{
${ }^{58} \mathrm{O}$ significado de relíquia está diretamente ligado a resto, mais precisamente ao resto do corpo após a morte, o que sobrou dele e/ou objetos que tiveram contato com ele. Ver sobre o assunto em BORGES, Nunes Júnior Ario. Relíquia: o destino do corpo na tradição cristã. 1. Ed. - São Paulo: Paulus, 2013.
} 
Aquele que experimentou Deus penetrou no reino da mística. A mística não assenta sobre o extraordinário, mas é a transfiguração do ordinário. O místico é aquele que se faz sensível ao outro lado da realidade. É aquele que capta o mistério (de mistério vem mística) que se revela e vela em cada ser e em cada evento da história pessoal e coletiva. E o capta porque aprendeu a ser sensível ao invisível aos olhos, mas sensível ao coração atento. (BOFF, 2002, p. 45)

O presente estudo buscou compreender, através de uma análise sócio antropológica, o despertar espiritual experimentado pela mística Lola, a partir de um recorte temporal, vivenciado no período de 1934 a 1999. A pesquisa nos forneceu um melhor entendimento acerca da construção do mito e do fenômeno denominado Santa Lola imerso na simbologia presente em seu cotidiano e no "mistério" do seu mundo interior.

Os traços de santidade de Lola que se encontram no imaginário de seus devotos, demonstram que o processo de santificação idealizado pelo povo é tão forte quanto o do Vaticano e nos remete a teoria do sociólogo e antropólogo francês Marcel Mauss no que diz respeito ao valor social dos fatos no qual enfatiza a importância das relações sociais para a afirmação de uma entidade.

o mágico australiano é o que ele é, sente o que ele sente, trata a si mesmo como ele o faz, e é tratado como ele é tratado, porque, para ele e para os outros, é um ser que a sociedade determina e leva a agir como seu personagem”. (MAUSS, 1979, p. 101)

Para a maioria dos seus devotos o seu processo de santificação iniciou quando ela caiu da jabuticabeira e que mesmo ainda sem o reconhecimento oficial da igreja, a devoção para com ela encontra-se cada vez mais forte e pode ser constatado no crescente número de fiéis que visitam sua antiga casa e seu túmulo, lhe atribuindo a realização de milagres.

Contudo, podemos perceber que Rio Pomba e região conhecem um fenômeno capaz de fomentar uma série de questionamentos e reflexões acerca de sua vida.

Lola desempenha um papel importante não só para os seus devotos como também para a cidade de Rio Pomba, na qual viveu desde os dois anos de idade até a sua morte. Ela simboliza um sentimento de pertença da cidade e não apenas da igreja católica.

Segundo OLIVEIRA (2008), os depoimentos recolhidos em sua pesquisa demonstram que muitas pessoas acreditavam que a jabuticabeira era de certa maneira sagrada tendo em vista o importante papel na vida de Lola e muitos iam lá e arrancavam pedaços da raiz, pois para eles era uma forma de estarem mais próximos dela e assim almejavam a possibilidade de ter uma graça alcançada. Diante disso podemos analisar a partir da teoria do antropólogo estruturalista Lévi-Strauss em sua obra "O Feiticeiro e a sua magia" sobre a feitiçaria e sua 
eficácia, discursando acerca da força do social que influencia e contribui para a sua legitimação.

Segundo Lévi-Strauss não importa se a magia é falsa ou verdadeira, o que importa é a sua eficácia na cura da doença ou na resolução de problemas.

a eficácia da magia implica na crença da magia, e que esta se apresenta sob três aspectos complementares: existe, inicialmente, a crença do feiticeiro na eficácia de suas técnicas; em seguida, a crença do doente que êle cura, ou da vítima que êle persegue, no poder do próprio feiticeiro; finalmente a confiança e as exigências da opinião coletiva [...] (LÉVI-STRAUSS, 1996, p. 194)

Com base nessas referências, compreendemos que Lévi-Strauss apresenta três aspectos relativos à crença e à eficácia da magia, formando um tripé para o seu efeito real. Primeiro: a crença do feiticeiro na sua própria magia; segundo: a crença do enfeitiçado na magia do feiticeiro; terceiro: a crença coletiva na magia do feiticeiro.

Lévi-Strauss nos faz perceber que a crença coletiva exerce uma força e contribui de forma significativa para a legitimação da eficácia da magia desenvolvida pelo feiticeiro, pois quando um grupo social está entranhado de uma ideia, de um conceito e/ou de uma opinião, o resto passa a refletir a partir da ideia imposta pelo social.

Não tem como afirmarmos se está certo ou errado, se é verdadeira ou falsa a magia, a verdade é que as pessoas fazem o que crêem e Lévi-Strauss afirma que a situação mágica é um fenômeno consensus. A eficácia da magia faz com que ela seja defendida pelo grupo social na qual foi desenvolvida.

Com base na abordagem Lévi-Straussiana, podemos fazer uma comparação do trabalho do feiticeiro ao de um psicanalista, considerando uma diferença no que diz respeito à condução para a cura do doente. Na prática da feitiçaria é necessário que o doente e o feiticeiro acreditem na magia para que ocorra a cura da doença; no viés da psicanálise, o paciente ao longo das sessões, estabelece uma relação de conversa com o psicanalista e, através de reflexões interiorizadas de si mesmo, obtém-se a "cura" ou a resolução de problemas independentes de acreditar ou não nas técnicas utilizadas pelo psicanalista.

As experiências do doente representam o aspecto menos importante do sistema, se se excetua o fato de que um doente curado com sucesso por um xamã está particularmente apto para se tornar, por sua vez, xamã, como se observa, ainda hoje em dia, na psicanálise. (LÉVI-STRAUSS, 1996, p. 208)

Para Lévi-Strauss o mito é muito mais importante que o rito, pois o mito traz explicações, é o simbólico, o que realmente possui significado para aquele que crê. Exemplo 
disso é que, para alguns grupos sociais, o sistema não tem como base a cura real de que se beneficiou esse ou aquele indivíduo, mas sim pelo sentimento de segurança criado no grupo pelo mito fundador da cura e os símbolos que o cercam.

O consenso do grupo social é indispensável no processo de cura através da magia, juntamente com a crença do feiticeiro em sua própria magia e do enfeitiçado na magia que está sendo realizada.

É inerente ao ser humano buscar, através da religiosidade, a solução para seus problemas e aflições. Podemos observar que a devoção dos fiéis manifestada à Lola que a considera como Santa possui características do catolicismo popular. Muitos estudiosos deste tipo de catolicismo, dentre eles Carlos Rodrigues Brandão, abordam a respeito da maneira do povo reelaborar e ressignificar sistemas próprios de crenças e práticas do sagrado ${ }^{59}$. Nas palavras de AZZI (AZZI apud PASSOS, 2002) dessa forma o povo expressa uma religiosidade espontânea e direta, contrapondo-se ao catolicismo oficial.

O elemento central no catolicismo popular tradicional e, por sua vez, da vivência popular do catolicismo, é o santo. A concepção popular sobre os santos vai além da noção pregada pela Igreja. Os santos são pessoas - isto é, seres individuais, dotados de liberdade, vontade, qualidades próprias e uma biografia - habitam o céu, estando junto de Deus, e por isso, tem poderes sobrenaturais. (TAVARES, 2013, p. 37)

O Catolicismo Popular no Brasil traz em sua gênese a relação do fiel com o Santo, seja ele reconhecido ou não pela igreja, relação essa de muita intimidade, pois para o devoto, o Santo é o intermediário com Deus, é rezar junto com ele e ter a certeza que seu pedido será atendido porque para o povo "Deus pode tudo", "Deus comanda", "Com Deus somos mais fortes", "Deus nos salva".

Outro elemento importante presente no catolicismo popular é o milagre que também demonstra a relação do fiel com o sagrado através da figura do santo, pois é ele que intercede junto a Deus para o consentimento de pedidos. Para o devoto não importa se a igreja reconhecerá ou não o ocorrido como um milagre. Muitas vezes as orações, sejam elas individuais ou coletivas, surgem para pedir ou agradecer graças alcançadas (BRANDÃO, 1980).

Nas palavras de Guimaraes Rosa "Com Deus existindo, tudo dá esperança: Sempre um milagre é possível, o mundo se resolve”. (ROSA, 1979, p. 76)

\footnotetext{
${ }^{59}$ Para tanto consultar BRANDÃO, Carlos Rodrigues. Os deuses do povo. São Paulo, Brasiliense, 1980.
} 
Os estudos acerca do catolicismo popular ganharam projeção nas décadas de 70 e $80^{60}$. Tais estudos fomentaram discussões para uma melhor compreensão dos inúmeros e diferentes fenômenos religiosos que são originários dos leigos e que pertencem primeiramente a uma religiosidade popular antes de qualquer tipo de reconhecimento institucional por parte da igreja.

Outro motivo que incentiva a prática do catolicismo popular por parte do fiel, é a identificação com o santo por este ser muito próximo da sua realidade, por ter sido uma pessoa que passou por sofrimentos e privações e no caso específico da Lola, o fato de muitos fiéis terem convivido diretamente com ela, reforça ainda mais a devoção e contribui para o processo de construção do mito Santa Lola.

\begin{abstract}
As muitas versões de histórias sobre a vida ou os feitos dos santos que são cultuados por católicos, independentes de terem sua origem na tradição oral ou na produção oficial da instituição católica, possuem uma matriz comum. Faço esta afirmação a partir da idéia da existência de uma "cultura bíblica" formulada por Otávio Velho, que nada mais é do que uma espécie de matriz simbólica ou um "pré-texto", como diz o autor, cuja função é servir de referência para se pensar as experiências vividas cotidianamente num contexto específico. Esta relação que há entre os fatos e eventos sociais com este pré-texto, ou melhor dizendo, com esta "cultura-bíblica", é o que revela o caráter fundamentalmente simbólico da realidade social (VELHO, 1995 apud SOARES, 2007).
\end{abstract}

\title{
Considerações Finais:
}

Esperamos que o presente estudo possa contribuir para uma melhor compreensão acerca do despertar espiritual experimentado pela mística Lola e entendermos como ocorreu a construção do mito que a eleva à condição de santidade antes mesmo do reconhecimento da Igreja Católica.

A partir de conceitos elaborados a respeito do catolicismo popular buscamos entender que os traços de santidade de Lola que se encontram no imaginário de seus devotos demonstram que o processo de santificação idealizado pelo povo é tão forte quanto o do Vaticano.

\footnotetext{
${ }^{60}$ Principais pesquisadores do catolicismo popular: AZZI (1978), BRANDÃO (1980), FERNANDES (1982), BEOZZO (1982) e ZALUAR (1983).
} 


\section{Referências Bibliográficas}

ALVES, Rubem. O que é religião. 9 ed. São Paulo: Brasiliense, 1986.

BOFF, Leonardo. Experimentar Deus: A transparência de todas as coisas. Campinas: Verus, 2002.

BOMTEMPO, Cláudio. O que o meu coração aprendeu. Barbacena: Centro Gráfico e Editora Ltda, 2005.

BORGES, Nunes Júnior Ario. Relíquia: o destino do corpo na tradição cristã. 1. Ed. - São Paulo: Paulus, 2013.

BRANDÃO, Carlos Rodrigues. Os deuses do povo. São Paulo: Ed. Brasiliense, 1980.

FERREIRA, Roberto Nogueira. Cem anos-luz!: o imparcial, 1896 - 1996, um jornal, um jornalista, uma cidade. Brasília: R.N. Ferreira, 1996.

O Sagrado Coração de Lola: a Santa de Rio Pomba. Brasília: Ed. L.G.E., 2007.

IBRAHIM, Márcio Antônio Deotti. O Grande Tesouro de Lola, 2007

Disponível em: www.santalola.com.br. Acesso em: 04 out. 2018.

LÉVI-STRAUSS, Claude. Antropologia Estrutural. Rio de Janeiro: Tempo Brasileiro, 1996.

MAUSS, Marcel. Antropologia. São Paulo: Ática, 1979.

OLIVEIRA, Simone Geralda de. Três Santas do Povo: Um estudo antropológico sobre santificações populares em Minas Gerais. Tese Doutorado defendida no Programa de PósGraduação em Ciência da Religião da Universidade Federal de Juiz de Fora, 2008.

PASSOS, Mauro. O catolicismo popular, In: PASSOS, Mauro (Org.) A festa na vida: significados e imagens. Petrópolis: Vozes, 2002.

ROSA, J.G.. Grande sertão: veredas. 13. ed. Rio de Janeiro: J. Olympio, 1979.

SILVEIRA, Stefany Silveira e Cosme Elias. "Santa Lola": trajetória social e origem da vocação religiosa da imagem sagrada do interior mineiro. In: Revista de Ciências Humanas, Viçosa, v. 15, n. 1, p. 273-292, jan./jun. 2015.

Disponivel em:

http://www.cch.ufv.br/revista/pdfs/vol15/artigo5evol15-1.pdf. Acesso em 04 jan. 2017.

SOARES, Hugo Ricardo. A produção social do Santo: um estudo do processo de beatificação do Padre Rodolfo Komórek. Dissertação defendida no Programa de PósGraduação em Antropologia Social da Universidade Estadual de Campinas - Instituto de Filosofia e Ciências Humanas, 2007.

TAVARES, Thiago Rodrigues. A religião vivida: expressões populares de religiosidade. In: Sacrilegens, Juiz de Fora, v. 10, n.2, p. 35-47, jul-dez/2013. Disponível em:

http://www.ufjf.br/sacrilegens/files/2014/07/10-2-4.pdf. Acesso em 02 out. 2018. 


\section{A espiritualidade expressa na Paróquia Divino Espírito Santo em Maringá, no Paraná (1970-2000)}

The spirituality expressed in Divino Espírito Santo Parish in Maringá, Paraná (1970-2000)

Marcia Regina de Oliveira Lupion ${ }^{61}$

mrolupion2@gmail.com

Resumo: Apresentar a formação da espiritualidade de paroquianos e simpatizantes a partir da vivência destes junto ao padre Bernardo Cnudde na cidade de Maringá, no Paraná, como resultado de fatos específicos promovidos pelo religioso em vida e na morte marcados pela crença na capacidade do padre em promover curas e exorcismos e, desta forma, responder às necessidades daquele que o procuravam.

Palavras-Chave: Padre Bernardo Cnudde. Espiritualidade. Individualidade.

Abstract: This study aims to present the formation of the parishioners and sympathizers spirituality from their experience with Father Bernardo Cnudde in the city of Maringá, Paraná. This formation was analysed as a result of specific events promoted by the religious, in life and death, marked by the belief in his capacity to promote cures and exorcisms and, in this way, to answer the needs of those who sought him.

Key words: Father Bernardo Cnudde. Spirituality. Individuality.

\section{Sobre este ensaio}

Neste ensaio apresentado durante a comunicação para o evento CONACIR Congresso Nacional de Pós-Graduação em Ciência das Religiões - organizado pelo Programa em Ciências da Religião da Universidade Federal de Juiz de Fora, Minas Gerais em novembro de 2018, a pretensão foi a de discorrer sobre a formação da espiritualidade de paroquianos e simpatizantes a partir da vivência destes junto ao padre Bernardo Cnudde na Paróquia Divino Espírito Santo em Maringá, no Paraná. Parte-se da ideia de que a espiritualidade vivida pelo grupo é resultado de fatos específicos promovidos pelo religioso marcados pela crença na capacidade do padre em promover curas e exorcismos e, desta forma, responder às necessidades daquele que o procuravam.

Em estudos recentes realizados a partir de entrevistas com pessoas conhecidas do monsenhor observou-se que durante os anos de 1969 e 2000, em plena implantação do processo de aggiornamento promovido pelo Vaticano II, a paróquia sob sua orientação ficou

\footnotetext{
${ }^{61}$ Doutoranda em História das Religiões pela Universidade Estadual de Maringá-PR e bolsista da Capes desde 2017.
} 
conhecida internacionalmente como sendo a Igreja em que o padre promovia curas e exorcismos. Dado o período em que tal fenômeno ocorreu e, cujos resquícios podem ser vistos ainda hoje nas manifestações junto ao túmulo do monsenhor e em celebrações específicas de um grupo específico da Renovação Carismática em Maringá no mesmo local e também na paróquia em que estão estabelecidos, acredito que a experiência espiritual vivida pelos paroquianos, simpatizantes e o padre, exemplifica uma característica da religiosidade moderna citada por Danièle Hervieu-Lèger que é a do indivíduo autônomo capaz de criar significados que deem sentido à sua existência. Considero ainda, que a individualidade expressa na afirmação de Hervieu-Lèger permite compreender alguns dos motivos pelos quais o grupo de católicos sob a orientação do monsenhor Bernardo não implantou efetivamente os pressupostos da renovação do catolicismo que no período eram as Comunidades Eclesiais de Base e seu caráter coletivo mas, teve como suporte para sua espiritualidade o acesso fácil a um padre que podia dar respostas e muitas vezes sanar dores emocionais, físicas e sociais de cada um especial.

Para a elaboração e verificação dessa proposição, que é parte da pesquisa de doutorado ainda inconclusa sobre o padre e sua prática religiosa, está sendo realizado um extenso trabalho de pesquisa nos acervos das paróquias da arquidiocese de Maringá com vistas, dentre outras informações, a encontrar traços que contribuam para a construção de sua biografia e também para a escrita do histórico da paróquia em que o mesmo atuou por trinta e um anos. Pesquisa nos Livros do Tombo e em documentos institucionais e pessoais tanto do padre quanto das paróquias permitiram conhecer um pouco da dinâmica vivida pela religião católica durante o processo de fundação e estabelecimento tanto da instituição já como diocese quanto do próprio município. Fontes construídas a partir da oralidade também tem sido de valiosa contribuição para conhecer a dinâmica da religiosidade praticada por Bernardo. Por enquanto foram feitas dezesseis entrevistas sendo dez delas com ex-paroquianos que estiveram em contato pessoal com o padre; três que conheceram o padre em missas e eventos, uma religiosa que conviveu com o padre em seus primeiros anos na diocese e dois depoentes praticantes da religião espírita.

$\mathrm{O}$ afeto resultante dessas relações tornou-se motivo para investigar a prática de Bernardo considerando dois pontos interligados entre si começando pelo papel desempenhado pelo crente na modernidade enquanto um indivíduo autônomo e, um vídeo produzido sobre o monsenhor após sua morte foi essencial nesse processo de visualização das emoções que acompanharam a morte de Bernardo. Dividido em quatro vídeos temáticos, o material foi de suma importância para observar a forma como o padre se expressava oral e fisicamente, traçar 
seu cotidiano como amante da pesca, seu apreço pelo fumo e pela gastronomia, a comoção da população diante de sua morte, a reverência de seus pares, detalhes do enterro e a missa de sétimo dia dentre outras tantas informações que o material pode fornecer.

Como dito acima, esse é apenas um ensaio e não tem a pretensão de ser a última palavra quanto às proposições aqui expostas sendo estas apenas análises que podem redundar em sínteses mais precisas quando finalizarmos o trabalho com as diversas fontes existentes. Por hora, seguem resultados parciais de uma discussão que tem se mostrado bastante profícua para a condução da pesquisa.

\section{Bernardo, padre e monsenhor}

Ao som dos cânticos religiosos católicos "Segura na mão de Deus" e "O sepulcro vazio está" e sob uma chuva de flores jogadas pelos presentes, desce o esquife de Bernardo na cova do cemitério municipal de Maringá no dia vinte e um de novembro do ano 2000. Com o fim do milênio se encerra também a trajetória de um padre cuja prática católica religiosa foi, no mínimo, peculiar perante aos seus pares. Francês de nascimento, Bernardo, que também foi monsenhor, chegou ao Brasil com 27 anos de idade. Formado num seminário de confissão missionária, sua intensão era servir o ministério no Haiti, mas, depois de breve estadia naquele país, acabou por se estabelecer em Maringá onde viveria e atuaria como padre por trinta e um anos praticamente na mesma paróquia, a Divino Espírito Santo onde um infarto fulminante, atribuído dentre outros fatores ao excesso do fumo, o levaria à morte em 20 de novembro do ano 2000.

Longe de estar esquecido, Bernardo continua vivo na memória local de forma bastante expressiva quando se considera que seu túmulo é o segundo mais visitado do cemitério municipal no dia de finados. Para além desse dia dedicado à visitação aos entes queridos, o túmulo do padre recebe visitas esporádicas em dias comuns como foi possível constatar em trabalhos de campo realizados ao longo da pesquisa. Fato significativo da persistência de homenagens a Bernardo é que, tanto no dia de finados como no aniversário da morte, seu túmulo é alvo de celebrações realizadas por integrantes do grupo carismático Filhos de Sião que foi o grupo acolhido por Bernardo lá pelos idos dos anos 1980 quando a Renovação Carismática ainda sofria forte resistência para existir e se fortalecer na já arquidiocese de Maringá.

Além dessas duas celebrações realizadas no cemitério, o grupo organiza missas nas quais os chamados "pais fundadores" do grupo, Bernardo e o padre Francisco Robl, ou padre 
Chiquinho como era conhecido, são homenageados informa Lucineide Negri (2018c), integrante do grupo e receptora confessa de milagres oriundos de Bernardo. Essas celebrações eucarísticas acontecem após o dia 20 de novembro quando se comemora o aniversário da morte tanto de Bernardo quanto dos três pais fundadores e costumam ser bastante elaboradas. Nesse dia são dispostos ao lado do altar quatro retratos emoldurados com aproximadamente oitenta centímetros de altura por sessenta de largura dos dois padres e dos três leigos ${ }^{62}$ e, durante no momento da apresentação dos dons são levados até o altar objetos que pertenceram aos falecidos como as bíblias dos pais fundadores e uma estola que pertenceu a Bernardo. Lucineide Negri (2018c) não faz menção a um objeto específico para o padre Chiquinho mas, informa que os objetos são chamados de relíquias pelo grupo tendo ela mesmo, em certa ocasião, feito a entrega da estola do padre para o celebrante que, ritualmente, a colocou em frente aos retratos assim como as demais relíquias trazidas pela assembleia.

Verifica-se dessa forma, um culto a Bernardo por parte desse grupo de forma exclusiva, mas, o apreço ao padre extrapola o grupo Filhos de Sião. Bernardo ficou conhecido internacionalmente como o padre que curava, mas, jamais abandonou os dogmas, ritos e comandos vindos da instituição católica a qual pertenceu desde 1966 quando se tornou padre ou, desde que nasceu e foi consagrado pelo pai a Jesus ou Nossa Senhora, há divergências entre os depoentes com relação a esse fato. No entanto, embora não tenha se afastado de sua formação católica, relatos informam que esteve envolvido em conhecer e interagir com outras religiões e religiosidades. Fato é que já em 1966, quando desembarca no Brasil e passa um breve período no Rio de Janeiro para aprender o idioma numa das extensões do Seminário francês a que pertencia, o jovem se dispõe a conhecer terreiros de umbanda e candomblé na cidade maravilhosa. Para o entrevistado Flávio Celestrino, católico e ex-ministro da eucaristia no período em que Bernardo foi pároco da Igreja Divino Espírito Santo, o padre tinha por objetivo "estudar" essas religiões, e, que tal pesquisa de campo apenas serviu para confirmar que a "verdadeira religião é a católica" (Celestrino, 2018).

Outros olhares sobre o padre, como do presidente do Centro Espírita Caminheiros o senhor Celso Eurípedes Martins (2018), que fica a poucos metros da Igreja Divino Espírito Santo, apresenta outra perspectiva para as incursões do padre a outras religiões. Segundo Celso, Bernardo "era vidente" e por ser dessa natureza, indicava a muitas pessoas que fossem até o Centro para poderem ser melhor atendidas quando sentia que não conseguiria fazer um atendimento adequado. Ainda de acordo com ele, Bernardo teria, ainda em criança observado

\footnotetext{
${ }^{62}$ Os chamados "pais fundadores" se constituem em um casal e uma jovem senhora. O casal está no mesmo
} retrato, e os dois padres e a jovem senhora em retratos individuais. Por isso são apenas quatro molduras. 
sua própria capacidade em "ver" os espíritos, daí que para esse senhor Bernardo era não só um vidente, mas também um médium dadas suas capacidades sobrenaturais de ver para além do mundo concreto. A relação de Bernardo com o Centro Caminheiros nunca se deu de forma explícita, e sim, discreta continua Celso, pois o padre preferia manter um certo grau de segredo para evitar conflitos sobretudo institucionais. De forma emblemática, o senhor Celso enfatiza que "padre Bernardo não era um católico, ele era um cristão" (Martins, 2018). E, para Carla Macharutto (2018), também espírita e cujo contato com o padre foi breve e não intencional, Bernardo foi um médium conhecido por sua capacidade de cura para com aqueles e aquelas que o procuravam.

Essas duas visões sobre Bernardo representam de forma bastante precisa o caráter místico sobre a qual a memória do monsenhor foi sendo construída e com a qual passou a ser lembrado, isto é, como um misto de padre católico, vidente, curador, com capacidades mediúnicas e sobretudo, acessível. Anselmo Frugério, paroquiano na Divino Espírito Santo desde a adolescência e hoje diácono, confirma a aura mística que foi se construindo sobre Bernardo a partir de sua personalidade e de sua prática religiosa ao informar que "ele era especial. O mínimo pra falar sobre ele é que ele era especial. Ele tinha uma coisa sobrenatural. De místico. Era só encontrar com ele" (Frugério, 2018).

Não era necessário ter um primeiro contato com o padre para conhecê-lo, sua fama o precedia não só na arquidiocese, mas também noutros estados e países da América. Conhecido como um padre que tinha o dom da cura, não demorou muito para que sua paróquia se torna-se um local de recepção de pessoas em busca de alívio para seus sofrimentos e que eram atendidas coletivamente durante as missas ou individualmente a partir de prévio agendamento, ou, com muita sorte, alguns poucos conseguiam falar com o padre logo após as celebrações eucarísticas.

Das dezesseis entrevistas realizadas, três depoentes atestam ter recebido a cura das mãos do padre, dois contam sobre ocasiões em que o padre praticou o exorcismo, vários afirmam que o padre informava quando já não havia mais chance de cura para o doente cuja intensão foi levada até ele. E, além disso, num caso específico relato de morte de um jovem por acidente, Bernardo dissera ao pai que esse tipo de morte não era da vontade de Deus com as seguintes palavras repetidas pelo senhor Benedito Negri, pai do jovem acidentado:

Aí lá ele (Bernardo) falou para mim: Olha meu filho, eu soube do que aconteceu com vocês. Mas, eu não estava aqui. Eu estava na França. Eu sei o quanto você está sofrendo. Mas, o que aconteceu com seu filho, não vai pensar que foi Deus que não foi não. Nem deus gostaria e gosta de ver vocês sofrendo desse jeito. Deus nos 
colocou aqui e permite que nós façamos o que quiser e ele permite e ele procurou esse caminho. (Negri, 2018a)

Embora aparentemente duras, as palavras de Bernardo serviram de conforto para essa família, que em um passado recente teria recebido a graça da cura para uma de suas filhas cuja doença não foi diagnosticada por nenhum médico, mas que havia sido curada logo após o padre fazer orações sobre a menina aspergindo água benta sobre a mesma. Conta a senhora Clarice Negri (2018b), mãe da criança e esposa do senhor Benedito Negri, que logo após realizar a oração ajoelhado ao lado da cama da criança, o padre teria pedido à família que, assim que ele saísse da casa, olhassem dentro do travesseiro da menina em busca de objetos estranhos. Feito isso, foi encontrado um amarrado de linhas e penas que foi prontamente queimado como orientara Bernardo e, desde então, a menina, de nome Lucineide Negri citada anteriormente, não apresentou mais aquele problema de saúde. Isso teria acontecido no ano de 1973.

Não é comum um padre apontar para a busca de certos objetos como detentores de intenções escusas como responsáveis por males sofridos, mas, diante desse fato narrado, observamos que Bernardo utilizava de diversos expedientes para atingir seu objetivo de aliviar os sofrimentos alheios ainda que tais expedientes ou práticas, não constem do cânone católico. No caso da doença de Lucineide, a existência de tal objeto está ligada ao universo religioso da Umbanda, fato que confere ainda mais diversidade à realidade religiosa vivida por Bernardo.

Anos depois, já uma jovem senhora, Lucineide Negri (2018c) tentaria suicídio tomando um número expressivo de comprimidos que, segundo ela, deveriam tê-la levado à morte. No entanto, não foi o que aconteceu. Lembra-se Lucineide que após ingerir os remédios, sonhou que o padre teria lhe dito que não só ela não morreria, mas que a medicação não lhe faria mal algum inclusive sem a necessidade de ir ao hospital. E assim aconteceu. Lucineide acordou sem qualquer resquício de ingestão abusiva de remédios e, a partir de então, credita a Bernardo não somente um, mas dois milagres de cura à sua pessoa.

Noutro entrevista, Neder Bittar (2018a) e Palmira Bittar (2018b), um casal de exparoquianos que conviveram intimamente com Bernardo participando com ele não somente de atividades na igreja mas, também por diversas vezes gozando de férias na praia de Guaratuba juntamente com o padre e outros casais, dentre as muitas recordações gravadas em quase 120 minutos de entrevista, contam duas situações em que o padre recorreu ao exorcismo. Os casos se deram quando o monsenhor foi chamado para atender duas mulheres jovens moradoras uma da própria paróquia e outra de Atalaia, cidade que fica há menos de 50 
minutos de carro de Maringá. Entre orações, aspersão de água benta e até mesmo um sonoro tapa no rosto de uma das jovens possuídas, Bernardo teria realizado o trabalho de libertação das jovens. O fato foi assim descrito por Neder,

\footnotetext{
Ligaram ele foi, chamou eu, eu fui e, a pessoa, a entidade lá rasgou a camisa dele, ele com autoridade falou "Em nome de Jesus e tal..." e a pessoa queria agredir ele e ele pegou e deu uma "chulapa" na cara dela. Aí ela foi embora a entidade. Foi essa a única vez que eu vi. Eu acho que ninguém mais viu não. (BITTAR, 2018a).
}

Flávio Celestrino (2018) conta ainda que, em certa ocasião, Bernardo foi chamado a uma residência para expulsar o demônio de uma mulher e que a certa altura o padre teria dito ao demônio: "Porque você não pega a mim que sou homem?" num momento de provocação uma vez que a possuída era uma mulher. Dito isso, a mulher se acalmou e o padre foi para casa. Lá chegando, a pessoa responsável por cuidar da casa de Bernardo diz ter olhado pela janela e visto o padre no carro com um vulto e, ao ver o padre ao entrar em casa sozinho perguntou quem era a outra pessoa que estava com ele no carro. A resposta teria sido: "Você não viu nada, e não chega perto de mim!”. Segundo Celestrino (2018), era comum o padre se recolher depois que realizar trabalhos mais exaustivos como exorcismos pedindo que fosse guardada sua privacidade por alguns momentos.

Os padres que conviveram com Bernardo engrossam o coro acerca de sua capacidade de cura ainda que de forma discreta focando seus exemplos de forma genérica no dom deste em curar crianças. Dom Murilo Krieger, hoje vice-presidente da CNBB, e na época responsável por celebrar a missa de corpo presente de Bernardo, assim se referiu a esse fato considerando que, caso cada um que conhecesse o monsenhor resolvesse contar sua história com ele, "muitas mães trariam o depoimento do carinho que ele tinha pelas crianças e das curas obtidas para seus filhos por sua oração e bênção" (Krieger, 2000). Essa descrição feita por Dom Murilo corrobora que sua prática em realizar rituais de cura eram do conhecimento de seus pares.

Para além desses fatos ligados à dor e ao sofrimento e, aos quais Bernardo atendia, de acordo com os entrevistados, "sempre na maior boa vontade", há também um evento ocorrido em data não precisada pelos entrevistados e que está ligado ao estabelecimento da Renovação Católica Carismática (RCC) na Igreja Divino Espírito Santo. Corria década de 1980 quando um grupo de católicos maringaenses resolveu fundar um grupo de oração de prática carismática denominado Grupo Filhos de Sião. Nessa época a RCC estava iniciando suas atividades no Brasil e, sua presença na arquidiocese não foi vista com bons olhos pelo clero local e até mesmo por parte dos leigos. Já Bernardo foi uma exceção. Ele acolheu o grupo em 
sua paróquia e este lá permaneceu até o ano de 2017 quando entraram em conflito com o atual pároco e se mudaram a para paróquia São Francisco de Assis. Esse é o grupo responsável por realizar todos os anos desde a morte de Bernardo, celebrações junto ao túmulo do padre no dia de finados, na data do aniversário de sua morte assim como a missa dedicada aos "pais fundadores" e aos padres citada anteriormente. A maior parte dos entrevistados fez ou faz parte da RCC na Divino Espírito Santo desde que o grupo lá se estabeleceu ou atualmente na paróquia São Francisco de Assis.

A chegada da RCC à paróquia Divino Espírito Santo acabou por desenvolver naquela comunidade um perfil diferenciado em relação a outras paróquias da arquidiocese. Enquanto as cartas pastorais propunham um alinhamento entre as igrejas latino-americanas e as propostas do Vaticano II, de Puebla e de Medellín, notadamente no que concerne a implantação das Comunidades Eclesiais de Base, as CEBs, na Divino Espírito Santo o que se viu foi o fortalecimento da RCC inclusive com a participação efetiva de Bernardo. Sobre essa situação se expressou o atual pároco, o monsenhor Júlio Antônio da Silva:

(...) o caso do padre Bernardo, monsenhor Bernardo, com a cabeça europeia, com os costumes europeus, ele não conseguiu digerir esse modelo de igreja latino americano. Por isso que foi, digamos assim, muito mais fácil ele abrir-se a um modelo europeu, um modelo de primeiro mundo, por que a RCC não sei se você sabe ela tem o seu nascimento na Europa com o Cardeal Suenens, belga, depois os americanos transpõem esse modelo de igreja para os Estados Unidos, então o pentecostalismo católico, para nós, passa via modelo americano (risos). (...) Mas isso não significou desunião, não significou racha. Pelo contrário! Respeitou-se o modelo, no caso aqui, o caso concreto, o padre Bernardo. (SILVA, 2018).

Dada essa relação do monsenhor com a RCC em sua paróquia poderíamos atribuir sua performance curadora ao rol de rituais comuns aos praticantes da renovação parece ser a lógica a ser seguida não fosse o fato de que o padre já apresentara, assim que pisou em terras brasileiras, o interesse por outras religiões e o fato de que a cura sobre a menina Lucineide Negri tenha ocorrido no ano de 1973, ou seja, bem antes da acolhida do padre ao grupo carismático. Além disso, conta Clarice Negri (2018b) que quando sua filha foi curada, o padre já era bastante conhecido por suas orações, bênçãos e aconselhamentos. O que nos leva a outra característica do monsenhor que era sua capacidade de ouvir e dar atenção aos que o procuravam, ainda que fosse em conversas "de corredor".

Nesse mosaico de características personalísticas, um outro elemento se destaca e que diz respeito ao fato de o padre fazer milagres o que contribuía para a construção de uma aura mística sobre o monsenhor. Mas, não grandes milagres como o ocorrido com Lucineide Negri por exemplo, e sim pequenos milagres ligados ao cotidiano descreve Palmira Bittar (2018b), 
paroquiana que conviveu cotidianamente com o padre durante a década de 1990. Conta ela que o padre realizava pequenos milagres como encontrar vagas em estacionamentos lotados e conter carros desgovernados em declives somente com as mãos. Flávio Celestrino (2018) relembra fato semelhante com detalhes mais precisos. Segundo ele, o padre teria descoberto o poder de sua fé quando ainda era seminarista em Saint Jacques e, não sabe se por descuido em deixar o carro do seminário desengatado, o mesmo começou a descer ladeira a baixo. Bernardo teria corrido em frente ao carro e, clamando por Nossa Senhora, teria conseguido contê-lo com suas próprias mãos. Pescar onde ninguém estava conseguindo pegar peixe algum também foi considerado um dos pequenos milagres do padre citados por Neder Bittar (2018a) e, a tudo isso, soma-se os relatos de que o padre teria sido visto em dois lugares ao mesmo tempo, configurando-se dessa forma, numa capacidade de bilocação por parte de Bernardo, fato citado por quatro entrevistados (Bittar, 2018a; Bittar, 2018b; Celestrino, 2018; Frugério, 2018). Fiquemos com o relato de Anselmo Frugério, hoje diácono e paroquiano desde a adolescência na Divino Espírito Santo.

\begin{abstract}
Então eu fico com um pouco de medo de espalhar algum boato. Não é nada oficial. Mas a gente ouvia muito isso com muita frequência. Pessoas que eram curadas na sala dele, essas orações que ele fazia para as lavouras, essa coisa da bilocação a gente também ouvia muito: alguém o viu em tal lugar, mas ele estava aqui celebrando a missa! A gente ouvia isso com muita frequência. É, é... algumas pessoas o viam fora daqui, mas ele estava aqui. São esses boatos que a gente ouve: olha alguém falou que viu ele em tal lugar, mas, ele estava aqui esse final de semana? Ele fez a missa. E era longe assim tipo Mato Grosso, não era aqui. Então a gente ouvia essas cosias, mas era jovem, as vezes era criança, então você não assimila muito bem isso. Mas a gente ouvia isso, a gente ouvia esses boatos. (Frugério, 2018).
\end{abstract}

De forma sintética, essas são algumas passagens que demonstram fatos ligados ao cotidiano de Bernardo e que lhe renderam a propaganda de ser um padre que praticava a cura e o exorcismo por possuir dons oriundos para uns de sua profunda fé e para outros por ser naturalmente um médium e ainda, por ser aquele que acolhe o doente, o que precisa de uma palavra de incentivo, o não católico ou um grupo religioso sem um local para realizar suas orações. Cada uma dessas formas de representar Bernardo são construídas a partir dos lugares de fala dos representantes o que os leva a operacionalizarem sua imagem explicativa do monsenhor de acordo com suas experiências simbólicas, culturais e com o próprio padre em particular. 


\section{A espiritualidade dos paroquianos e simpatizantes de Bernardo}

De acordo com Danièle Hervieu-Lèger (2015), a Modernidade se caracteriza por três traços específicos e explicativos de desenvolvimento que são a racionalidade e seu imperativo em adaptar-se de forma coerente os meios aos fins desejados; a capacidade dos indivíduos em fazer o mundo em que ele vive algo significativo e que dê sentido à sua própria existência configurando-se num indivíduo-sujeito com autonomia de escolhas e decisões e, por último, mas não menos relevante, a socióloga considera que um tipo particular de organização social marcada pela diferenciação social das instituições como sendo o terceiro pilar sobre o qual a modernidade se sustenta.

Não nos cabe aqui discutir a primeira e a terceira características da Modernidade listadas por Hervieu-Lèger por ainda não terem sido aprofundadas as pesquisas nesse sentido, de forma que apenas a capacidade de autonomia dos indivíduos-sujeitos receberá nossa atenção uma vez que por meio dessa característica é possível refletir acerca da relação estabelecida entre o padre e aqueles que se tornaram seus simpatizantes sem perder de vista tanto o caráter racionalista da modernidade quanto sua capacidade em criar instituições diversas para atender às diversas esferas que fundamentam uma sociedade.

Nesse sentido, temos que ser um indivíduo autônomo é alguém que, dentro da mentalidade funcionalista da sociedade moderna, inscrita no imediatismo que a caracteriza e que para existir não pode renunciar a traços de continuidade relativos à "memoria autorizada" que é a tradição" (Hervieu-Léger, 2015, p. 27), constrói seus significados apoiado em formas já conhecidas e em novidades por ele desenvolvidas por meio de suas experiências simbólicas, materiais e no trato com o outro. É nessa dinâmica de mutações de sentidos, ações, instituições, filosofias, crenças, etc., na qual o indivíduo-sujeito provido de sua capacidade de autonomia na construção de seu mundo e suas explicações pode ser representado pelos paroquianos e simpatizantes de Bernardo.

Por meio de relação entre o pastor e seu rebanho, estabeleceu-se na paróquia Divino Espírito Santo uma espiritualidade particular na qual interagiram três segmentos distintos e não equivalentes. O primeiro deles e o de menor âmbito é a implantação das propostas presentes no Vaticano II, em Medellín e Puebla em relação às CEBs e, o segundo segmento, esse bem mais abundante, é constituído por elementos da religiosidade carismática enquanto o terceiro cabe à prática da religiosidade particular de Bernardo notadamente no que diz respeito à sua aura de místico como curador e sua disposição em atender aos que o procuravam em meio às dores físicas, morais ou espirituais. Inscrita nesse tripé, a 
espiritualidade praticada pelos paroquianos da igreja Divino Espírito Santo ao mesmo tempo que aponta para uma coletividade no sentido das celebrações indica uma individualidade no atendimento por parte do padre que, com sua forma de agir, levou a espiritualidade praticada na Paróquia Divino Espírito a somar o novo imperativo do Vaticano II e concílios correlatos ao crer e práticas carismáticas tendo como figura central, a figura de um Bernardo ao mesmo tempo representante da Igreja Católica - seu lugar de fala institucional - e o Bernardo místico, capaz de se desprender desse lugar de fala e buscar atendimentos, práticas e rituais de outras religiosidades como a espírita e a umbanda desde que dessem conta de atender ao seu "bom e amado povo", como ele gostava de referir aos que o procuravam.

Esse atendimento individual e voltado para a audição e aconselhamento daqueles que o procuravam e que por vezes resultaram em curas não só de ordem psicológica mas físicas, seguia naquele momento, o movimento inverso do desejado para o leigo inserido nas CEBs a quem era solicitado uma ativa participação na igreja no sentido de um engajamento em relação às dores e sofrimentos coletivos quando muito se falava do "cristão engajado", aquele que se envolvia na "luta" por melhores condições de vida para a comunidade e de trabalho para os trabalhadores por exemplo. Na Constituição Pastoral Gaudium et Spes o perfil do leigo preocupado com a coletividade é assim descrito o "homem se fortalece, ao contrário, quando compreende as inevitáveis necessidades da vida social, assume as exigências multiformes da solidariedade humana e se responsabiliza pelo serviço à comunidade humana" (Vier, 1968, p. 174).

Como dito acima, não será esse leigo que prosperará na Divino Espírito Santo e sim, aquele que, embora trabalhasse nas atividades da igreja como quermesses, almoços beneficentes, obras de atendimento aos necessitados como a confecção do Roupeiro de Santa Rita para as mães parturientes, se sentia querido e amparado pelo atendimento particularizado de seu pároco. Atendimento esse gerador de uma relação afetiva e sensível na qual estavam envolvidos o padre, seus paroquianos e todos aqueles e aquelas que o procuravam.

\section{Referências}

BITTAR, Neder. Entrevista. Entrevista concedida a Marcia Regina de Oliveira Lupion. Maringá, 2018a.

BITTAR, Palmira. Entrevista. Entrevista concedida a Marcia Regina de Oliveira Lupion. Maringá, 2018b.

FRUGÉRIO, Anselmo. Entrevista. Entrevista concedida a Marcia Regina de Oliveira Lupion. Maringá, 2018.

HERVIEU-LEGER, D. O peregrino e o convertido: a religião em movimento. Tradução de João Batista Kreuch. 2. ed. Petrópolis, RJ: Vozes, 2015. 238 p. 
KRIEGER, Murilo scj. (Dom). O amor ultrapassa o tempo. Diário do Norte, Maringá, 23 nov. 2000. s/p.

MACHARUTTO, Carla. Entrevista. Entrevista concedida a Marcia Regina de Oliveira Lupion. Maringá, 2018.

MARTINS, Celso Eurípedes. Entrevista. Entrevista concedida a Marcia Regina de Oliveira Lupion. Maringá, 2018.

NEGRI, Benedito. Entrevista. Entrevista concedida a Marcia Regina de Oliveira Lupion. Maringá, 2018a.

NEGRI, Clarice. Entrevista. Entrevista concedida a Marcia Regina de Oliveira Lupion. Maringá, 2018b.

NEGRI, Lucineide. Entrevista. Entrevista concedida a Marcia Regina de Oliveira Lupion. Maringá, 2018c.

SILVA, Júlio Antonio (Mons.). Entrevista. Entrevista concedida a Marcia Regina de Oliveira Lupion. Maringá, 2018.

VIER, Frederico (Frei, O.F.M). Compêndio do Vaticano II: Constituições, decretos, declarações. 11. ed. Petrópolis, RJ: Vozes, 1968. p. 174. 